'outsidèrs' and most Importantly created a bond, a sense of 'national' fdentity between the Jewish communities throughout the world. The defintion of a Jew was therefore regarded as axiomatic: a Jew was an Individual who was either born to a Jewish mother or who converted to Judaism. ${ }^{3}$ The fact that the Jew observed and obeyed the halakha (traditional Jewish religious law) was not questioned; it was taken for granted. Identity and religious observance were one. And in a time period when the 'outsiders' also defined themselves along religious Itnes, this was relatively unproblematic. With the rise of nation-states however, the Jews were confronted with crucial questions of identity.

With the creation of nation-states in the nineteenth century, peoples' identities were revolutionized from ones based on religion to ones based on ethnic and territorial criteria. So long as peoplehood had been defined by cultural-religious values, Judaism had been able to serve as a basis for Jewish national identity. The newly created modern nation-state's however left no room for autonomous Jewish communities and demanded ethnic national loyalties. How exactly were the Jews to 'fit in' these new Gentile 'nation-states'? Were they as Jews a "nation of their own or Frenchmen [or whatever] with a particular religious bellef?" 4 Their problem therefore was not one merely of external pressure to assimilate and identify with the nation-state, but more importantly, one of their own inner conflict. Whs their future to be one of traditionalisw or modernism, orthodoxy or liberalism, ghettoization or secularization? Should the Jews become 'normal', leave 


\section{National Library}

of Canada

Canadian Theses Service

Ottawa, Canada

K1A ON 4

\section{Bibliotheque nationale} du Canada

Service des theses canadiennes

\section{NOTICE}

The quality of this microform is heavily dependent upon the quality of the original thesis submitted for microfilming. Every effort has been made to ensure the highest quality of reproduction possible.

If pages are missing, contact the university which granted the degree. .

Some pages may have indistinct print especially if the original pages were typed with a poor typewriter ribbon or if the university sent us an inferior photocopy.

Previously copyrighted materials (journal aticles, published tests, etc.) are not filmed.

Reproduction in full or in part of this microform is govemed by the Canadian Copyright ACt. R.S.C. 1970, c. C-30.

\begin{abstract}
AVIS
La qualité de cette microlorme dépend grandemenl de la qualité de la thèse soumise au microtilmage. Nous avons tout fait pour assurer une qualité supérieure de reproduction.

S'il manque des pages, veuillez communiquer avec l'universite qui a contéré le grade.

La qualité d'impression de certaines pages peut laisser à désirer, surtout si les pages originales ont élé dactylogra. phiées à l'aide d'un ruban usé ou si l'universilé nous a lait parvenir une photocopie de qualité inférieure.

Les documents qui font déjả l'objet d'un droit d'auteur (articles de revue, tests publiés, etc.) ne sont pas microfilmés.
\end{abstract}

La reproduction, méme partielle, de celte microforme est soumise à la Loi canadienne sur le droil d'auteur. SRC 1970 , c. C-30. 


\section{RELIGION AND THE RESTRUCTURING OF NÁTIONAL IDENTITY IN ISRAEL: \\ A HISTORICAL ANALYSIS}

by

Janine A. Clark, B.E.S.:

A thesis submitted to

the faculty of Graduate Studies and Research.

in partial fulfiliment of

the requirements for the degree of

Master of Arts

Department of Political Science 


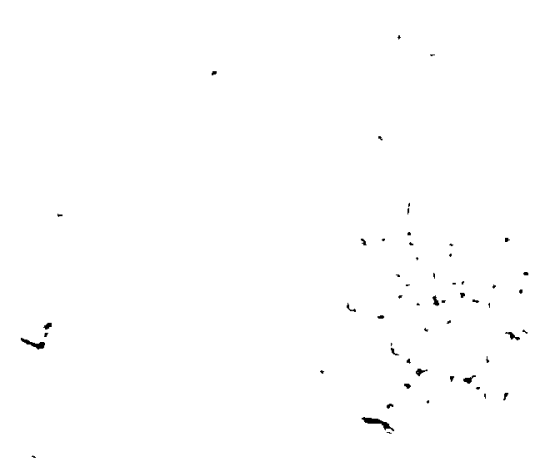

Permission has been granted to the National Library of Canada to nicrofilm this thesis and to lend or sell copies of the film.

L'autorlsation a bte accordbe d la Blbllothdque nationale du Canada de microfliner cette these et de proter ou de vendre des exemplaires du film.

The author (copyright owner) has reserved other publication rights, and -neither the theels nor extensive extracts from it may be printed or. otherwise reproduced without his/her written permision.

L'auteur (t1tulalre du drolt d'auteur) se reserve les autres droits de publication; ni la thase ni de longs extraits de celle-ci ne dolvent atre 1mprimes ou autrement reprodults sans on autorisation ferite.

I SBN $\quad 0-315-46305-8$ 
The undersigned recomend to the Faculty of Graduate studies and Research acceptance of the thesis

RELIGION AND THE RESTRUCTURING OF NATIONAL IDENTITY IN ISRAEL: A HISTORICAL ANALYSIS submitted by Janine Clark, B.t.s.

in partial fulfilment of the requirements for the degree of Master of Arts
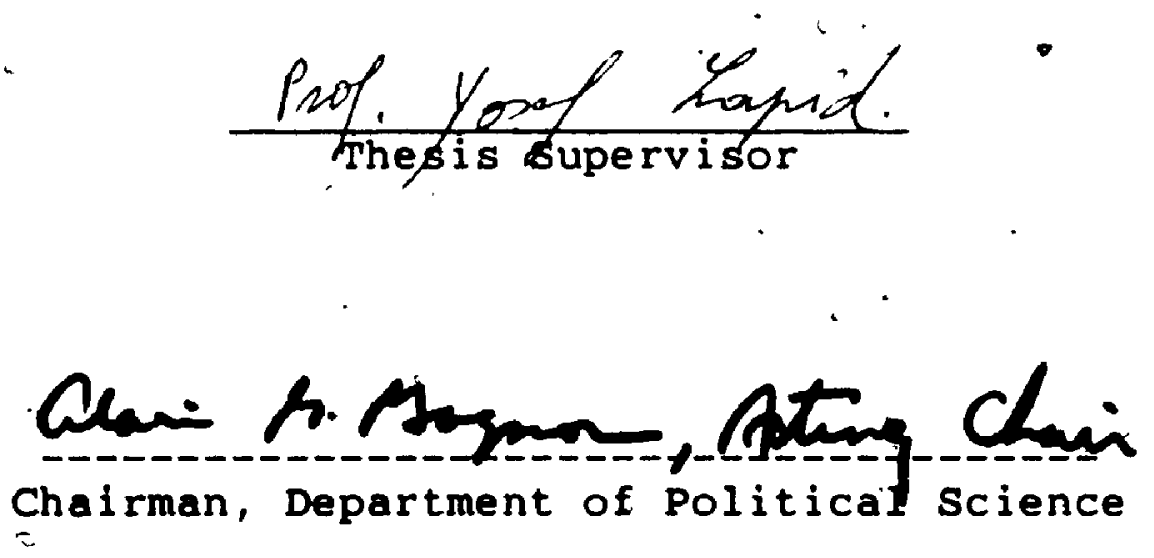

Carleton University

$$
\text { June 2, } 1988
$$




\section{Abstract}

Religious-secular tensions in Israel today are a result of a restructuring of its national identity. This period of national self-definition represents a search for a new relationship between the secular notion of nationhood based upon ethnicity and the religious definition based upon adherence to Jewish law. For the majority of Israelis the two definitions cannot be separated, hence the debate can be viewed as one between secular "zionists, non-Zionists, anti-Zionists and religious Zionists; each purports

a different balance or restructuring between the two components of nationhood. This present-day search for a new national identity in Israel is historically similar to the identity crisis within the European diasporic Jewish communities which triggered the rise of Zionism in the nineteenth century. Due to the tension between the two notions of nation inherent within Zionism, it may be expected to occur again in the future. 


\section{Iable of Contents}

Page

Abstract.........................

Table of Contents...................... i

Chapter One:

Introduction. ..........................

Chapter Two:

The Role of Religion in Theories of

Nationalism and Politics............... 20

Chapter Three:

Jewish Nationhood and the Rise of the Nation-State:

A Crisis of National Identity............. 44

Chapter four:

Religious Zionists, Anti-Zionists and Non-Zionists:

Religious Reaction to the Secular Zionist

Movement......................... 65

Chapter Five:

Continuity and Change:

The Decline of Socialist Zionism and the

Search for a New National Identity......... 95

Chapter Six:

- Conctusions........................... 121

Bibl iography........................... 137

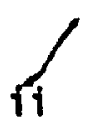


Chapter One

\section{Introduction}

The 1980 s seem to be the decade of religious 'fanaticism'. In Iran, the Ayatollah Khomeini swept the Shah out of power, religlous extremists held America hostage for over a year, and an endless supply of martyrs continue pouring into the battle field against Iraq and ultimately their death in the name of Allah. Lebanon and the increasing power of the Hezbollah seem to be following suite, aggravating an already fanatical and drawn-out civil war. In Egypt religious discontent brews beneath a tightly-kept lid, while the Soviet Union fears the spread of Islamic 'fundamentalism' to its own Muslim populations within its borders. Throughout much of Latin America, the Church is engaging in bitter struggies against authoritarian regimes. that often end in violence and death. Religious tensions appear to have no end in India or Pakistan. And in the United States, religious movements and leaders are gaining momentum and presenting a considerable challenge in the political sphere.

As religious fundamentalism has appeared to be sweeping across. the globe, especially in the Middle East, some expected Israel to represent an iṣland of 'sanity'; Israel was after all presumably a modern secular democratic nation,státe. Yet weekly demonstrations, sometimes violent, occur in front of movie houses and restaurants that are permitted to open on the Sabbath. Even soccer games have become a source of contention. Government representatives, in particular tax 
collectors, venturing into the Orthodox neighbourhood of Jerusalem prepare themselves for an onslaught of.stones by those ultra-Orthodox who refuse to recognise the state of Israel and its secular ways. Hotel kitchens have to conform to strict religious dietary rules; and hotels are threatened yearly with the withdrawal of their 'kosher license' if they hold a New Year's celebration on the Gentile holiday. In addition, the national airline, EL AL, is grounded on Saturdays and other holy days. Under religious pressure, the government placed restrictions on abortions, autopsies and transplant operations, all of which are highly disapproved of by the religious purists. ${ }^{1}$ Furthermore, only orthodox rabbis can perform marriages, grant divorces and conduct funerals. In 1986, to name just one example, the ultra-Orthodox threw the Israeli cabinet into a crisis by demanding that" due to the 'shmitta', the sabbatical year of the Jewish calendar, during which Jews must leave their fields fallow and refrain from eating grains or vegetables. harvested during the year), Israel's wheat crop be exported and non-Jewish wheat be imported for consumption. ${ }^{2}$, Probably one of the earlier images from Israel, at least in terms of what the international community took particular note of, was one of vandalized and razed bus shelters, destroyed because of their advertisements of women wearing swimming suits or other such immodest images. The question is why has this 'sudden" "militancy gripped Israel?

To call it the 'war of the bus shel,ters' would be to grossly oversimplify the mounting terision in Israel: if is not merely a question of 'promiscuous' advertisements blemishing the bus stops of 
jerusalem. Nor is it a simple question of legislation. The 'laws' themselves are not essentially in dispute. It is the vision behind those laws, a 'battle' between visions of what sort of soclety Israel is to be. It is therefore a struggle over the national identity of Israel: Is Israel to be a Jewish state or a state for the Jews? Is the nation to be 'bound' by Jewish practices or by ethnic ties? In other words, is Israeli national identity to be determined by religion or by 'nationality' as the Western world knows it?

The religious tensions within Israel today reflect a nation that is struggling to define itself. It is not a 'war' between religious and secular. Jews. It is not a straight-forward question of whether the Israel of the future wilt be a modern or a traditional one, a secular or a religious one. It is however an issue between the shades of Zionists and non-Zionists, anti-Zionists and 'ultra-nationalists'. It is a question of what balance, what relationsh/p/wijl be establisheg between retigion. and nationalișm, between Judatsm and Zionism in Israel. It is a period of self-questioning, self-defining that Israel has-been undergoing since the conquest of Judea and Samaria, the occupted West Bank, in the 1967 War.

The concept of nationalism itself is merely 200 years old. Previous to the rise and development of nation-states in Europe, self-identity had been based on religion. In Europe sherefore one saw oneself primarily as -being a Christian. So too was the situation for the Jewish minorittes living within Europe. It was Judaism which bound together the community in outlook and lifestyle, Jewish practfces which $\sim$ 
'outsidèrs' and most importantly created a bond, a sense of 'national' identity between the Jewish communities throughout the world. The definition of a Jew was therefore regarded as axiomatic: a Jew was an Individual who was efther born to a Jewish mother or who converted to Judaism. ${ }^{3}$ The fact that the Jew observed and obeyed the halakha (traditional Jewish religious law) was not questioned; it was taken for granted. Identity and religious observance were one. And in a time period when the 'outsiders' also defined themselves along religious Itnes, this was relatively unproblematic. With the rise of nation-states however, the Jews were confronted with crucial questions of identity.

With the creation of nation-states in the nineteenth century, peoples' identities were revolutionized from ones based on religion to ones based on ethnic and territorial criteria. So long as peoplehood had been defined by cultural-religious values, Judaism had been able to serve as a basis for Jewish national identity. The newly created modern nation-states however left no room for autonomous Jewish communities and demanded ethnic national loyalties. How exactly were the Jews to 'fit In' these new Gentile 'nation-states'? Were they as jews a "nation of their own or Frenchmen [or whatever] with a particular religious belief?"4 Their problem therefore was not one merely of external pressure to assimilate and identify with the nation-state, but more importantly, one of their own inner conflict. Was their future to be one of traditionalism or modernism, orthodoxy or liberalism, ghettoization or secularization? Should the Jew's become 'normal', leave 
their ghettos and enter the surrounding Gentile population? What would it mean to be Jewish in a secular society?

Enlightened, Jews "tried to resolve this crisis ... by splitting their identi,ty into a non-Jewish national component and a Jewish cultural component." 5 With this separation of the nation from religious faith, "the process of assimilation of individual Jews into Gentile society [was consequently accelerated] as never before." 6 For the first time, the biblical definition of the Hebrew people as "a people that shall dwell alone and shall not be reckoned among nations" lost its significance; the people no longer wanted to dwell alone in traditional Jewish society, segregated from the rapidly modernizing world. 7 In what can be considered a mass conversion, at least twenty or thirty percent of the Jews were soon to abandon their religion as a lifestyle and join - that of the secular Gentile world. 8 . This rejection of ghetto $11 \mathrm{fe}$ and the secularization of the Jewish communfty however must be seen as much more than a mere abandonment of religious falth, for it was a loss of an entire people's identity. ${ }^{9}$ Without its religious, cultural and national components, Jewish national consciousness appeared unable to exist. With the separation of nationhood from fafth, the very essence of Judaism and Jewish identity came into question. What did it mean to be Jewish in the new nation-states? How would the Jewish people survive and reproduce itself in this new world of pressumably secular. nation-states?

With the growing anti-semitism of the West and the shocking pogroms of Eastern Europe, the crisis of Jewish identity exploded. The 
attempt at secularization and integration into European Gentile society seemed like a horrible failure. To the Jews of nineteenth century Europe there seemed no choice but to

emigrate to a more welcoming gentile society to continue with their hybrid national identity, to obtain their own territory and thus delineate the boundaries of the ir own identity geographically. 10

It was in this context that Zionism arose.

Zionism, the outcome of which was the creation of the state of Israel, was established in order to 'normalize' the Jewish condition. Israel was to mean that the Jews would be a normal nation; a 'normal' nation in a 'normal' nation-state. Normalization meant the end of a diasporic existence, and more importantiy, the end of a people bound by religious ties and the creation of a nation bound by ethnic ties. Furthermore, it was a realization of the failure of Jewish Emanchation'; that Jews could be a Germans or Frenchmen on the street and lews in their homes. While assimilation had occurred at an alarming rate, persecution had not ceased. The only solution appeared to be the creation of a land, a state for the Jews.

This simple solution however formented a revolution in Jewish identity. Zionism wanted to develop a "new Jew'; to change the "anti-semitic, stereotype" which" passively waited for the coming of the Messiah, into a militant, fiercely independent Jew fearing nobody. 11 For many, the Jews could no longer wait for the Messiah to lead them to the Iand of Zion, thexwore going to have to take matters in their own hands and give Him a little puch. 
Zionism's task therefore was broader and more challenging than 'merely' creating a nation-state as other national movements. Jewish nationalists sought an ideological substitute for religion which would mobilise and integrate the commity and legitimate their particular. vision of the Jewish future and society. Labour Zionism therefore, which became the dominant Zionist movement, was to marry the "two most potent and most history-minded of modern ideologies--nationalism and socialism."12 It was to do so by the use of traditional religlous. symbols which would be "so heavily charged with associations and emotions which had accumulated in the collective memory ... [ that they. would be] able to nourish the whole complex of feelings and aspirations" needed in the creation of a new soctety and state. 13 Soctalism was to, give Jewish nationalism whole new set of values that would serve not only as an integrative goal but also as a strategy for the sucdessful development of a Jewish society.

Labour Zionism therefore took the original Messianic hope and reinterpreted it with nationalistic and socialistic concepts. The biblical Messianic aspiration states that the "Jews will be liberated politically by a Messiah sent by God to be their king and èstablish a new social order of perfect'justice and peace." 14 Once in the diaspora, - the emphasis then changed from one of political action to "the spiritual aspect of liberation, redemption ... a religious ethical preparation of the individual was prescribed, to make the world worthy of salvation." 15 The Messianic hope therefore came to comprise three main components: 
political liberation, social change, and individual salvation. Using nationalist and socialist interpretations, Labour Zionism

provided for national redemption by immigration to Palestine; social redemption was to be achieved by setting up an egalitarian society, of which the kibbutzim were the primary example; individual

-salvation was to come by tilling the Holy Land, that is by physical contact with its soil.16

In the building of a new society and a Jewish state, Zionism was thus to prectpitate a revolution in the Jew's image of himself and his way of life.

Religious reaction to the new $Z$ ionists in the late nineteenth century was, to be sure, predictably severe. For these traditional Jews it was a sin to anticipate the Messiah and in essence to take on a divine role and determine $\mathrm{His}$ hand for Him. Reaction varied however as religious groups came to terms with Zionism and Zionist settlements in Palestine in a variety of ways. Religion was determined not to be 'replaced' by this new tionalism; other than totally rejecting Zionism therefore different interpretations of Zionism arose as the religtous-minded established some form of relationship with the new movement. While for Naturei Karta (Guardians of the City) Israel was not to be recognized, for Merkaz Ruhani (Spiritual Centre) it was the concept of a seculaf Israel, not the state itself, that was unacceptable and had to be changed. Yet other religious Zionists, such as Rav Kook, the first Chlef Rabbl of Palestine, regarded the political actions of the secularists as a real part of His Divine $\boldsymbol{p l}$ lan (whether the secularists knew it or not). Jews therefore were for the first $t$ ime not 
only divided along religious-secular lines, but divisions arose'within the religiously-minded themselves. It was with this variety of accommodations which the religiously-minded made with the 2 lonist movement that the new state came into existence.

Much of the credit for such an achievement lies with Israel's first prime minister, David Ben-Gurion. It was Ben-Gurion who created the 'status quo' that has guided Israel throughout its history. While avoiding the divisive issue of creating a constitution, religlous and secular Jews came to an agreement regarding the nature of the state which seemed suitable to the accommodation each group would allow.

On June 19, 1947, Ben-Gurion, on behalf of the Jewish Agency, committed the leadership of the future Jewish state to the continuation of the status quo that had been maintained under the British Mandate in four areas of religious practice: the Jewish Sabbath was to be the official weekly day of rest; kitchens in public institutions serving food to Jews would be kosher; great efforts would be made to ensure that the Jewish people did not split over issues of marriage and divorce; and a Targe measure of autonomy would be guaranteed to religlous schools. 17 Appropriately vague, the status quo letter went on to serve as the basis for countless caalition agreements and legislation in determining official practice in areas of religious-secular conflict. ${ }^{18}$ In return for these domestic guarantees, orthodox leaders of the future National Religious Party tacitly agreed to refrain from interference in foreign and other state affairs. The "result was a messy but extremely viable 'modus vivendi" "between the secular majority and the religlous minority 
In Israel.19 It appeared that the Jewish condition had been 'normalized'.

Questions regarding the national identity of the new' state were thought to have been solved. The secular socialist zionist had' 'won the day'. By bringing nationality and loyalty to a uniquely Jewish state, Zlonism made possible for every Jew who so desired a secular identity whlle remaining 'Jewish'.' The role religion had previously held in binding together the Jewish 'nation' had been replaced by ethno-nationalism. Zionism had successfully 'normalised' the Jewish condition which included offering a secular national definition of the essence of Judaism.

Yet today within Israel, forty years after the creation of the state, questions concerning the national identity in Israel still abound. Debates within Knesset revolve not around 'Who is an Israeli?', but 'Who is a Jew?'. This debate essentially is one of whether or not a Jew is one who obeys the laws of halakha. 20 Under the 'Law of Return', Jews enjoy an almost unrestricted right of immigration to Israel. 21 According to current finitions, "a Jew is anyone born of a Jewish mother or who has converfed and is not a member of any other religion. But the religious parties want this formula tightened up to insist that conversion be by orthodox religious law only. "22 While in immediate, practical terms this. would have most effect upon Jews outside of Israel, In a country where the vast majority of Jews are basically secular, the essentyal issue for Israel, is the precedent this would be setting for the future in terms of how. Israel and Israelis are to be defined. 
Similarly, the 'Constitution debate' lies at the heart of the problem of national identity. The issue is not a straight forward one of the religious Jews refusing to regard anything other than the Torah as a valid constitution. 23 The secular Jews themselves are torn as to the place of Judaism in Israel's national identity: To quote a member of Knesset, ". $\therefore$ the Constitution is the credo of the nation; it symbolizes whatever is good and noble in a people; therefore we do not wish the Constitution to express the distorted view in which there is no essential continuity with the State of Israel 2,000 years ago." 24 In trying to express "that which has been characteristic of [the Jewish]. people in the past and present and in the future ..." Israel has remained too divided over the question of identity to agree upon a constitution. 25 Why does this separation of religious and secular issues still appear incomplete? Why has this national debate between the religious and the secular emerged?

To a large degree, the answer lies in the nature of Judaism itself. For Judaism is more than a falth per se, it contains the concept of a distinct peoplehood with the Jews as a nation fulfilling a specific purpose or divine mission throughout history. To attempt to separate national identity from Judaism therefore is perceived as a threat by the religious to the religion itself. As mentioned above, such a threat is even comprehensible to many secular Israelis. Most Israelis accept that Judaism and Zionism are inextricably bound up.

As Shimon Peres noted in a speech to the Knesset in the wall of ... [a 1986] arson attack on a synagogue, 'There is no Zionism without the Jewish heritage, and there is no Judaism in our 
times without the Zionist vision.' What [secular Israelis] do not want is religious coercion. But the widespread acceptance that Israel is and should remain in some sense an

identifiably Jewish state means that the Western-style remedy for such problems, clear separation between

'church and state', is netther applicable nor appropriate to the Israeli case. 26

The issue therefore is not one of secularization, nor the growth or decline of religious movements, but of a restructuring of the relationship between religious and secular identity. Israel is struggling to define itself; and it is a struggle which has occurred and arguably will occur again and again throughout its history. The example of Israel thus suggests something too often denied about the nature of religion itself: that change in religion is normal and continuous (despite religion's own protestations to the contrary). 27

Questions which haven't been raised since the appearance of the Zlonist movement at the end of the nineteenth century are being raised today. While under different circumstances, the same questions and the same divisions that existed between the 'enlightened' Jew and the 'unenlightened' Jew, the Jew who defined national identity according to Halakha and the Jew who defined it according to ethnicity, are occurring anew. As a nationalist movement, Zionism did not, in fact deal with the actual root of the 'Jewish question' and the consequent identity crisis which Jews of the diaspora were experiencing. By providing Jews with a secular national loyalty or 'peoplehood', political Zionism actually tried to sidestep the issue of what it essentially meant to be Jewish. The question therefore becomes not why this religious-secular national debate is occurring in Israel, but why is it re-occurring now ? 
A change in the shape and the balance of components of Zionism was to occur almost immediately after the creation of the state and the achievement of Zionism's primary goal. As Jews from around the world, unimbued with the Zionist ideology, flooded into Israel, the socialist element was to decline as Zionism took on a greater religlous significance. Furthermore, the religious component of ziontsm was to strengthen under the separate national religlous school system. ${ }^{28}$ Labour Zionism's ideology seems to have crumbled as a strategy and as an identity. It was the 1967 Six Day War that acted as the catalyst in exposing Israel's need for a national identity. The conquest and subsequent occupation of populous Arab areas compelled Israel to look at itself not only in terms of its goals but also in terms of the very nature of the Zionist state. While the context was different, essentially the same type of questions were being asked as those asked by nineteenth century Jews. What was the nature of the Jewish people? What did it mean to be a Jewish state? Most importantly however, the Six Day War also marked a turning point for many of the Orthodox Jews: "... it sparked a religious awakening and a growing sense of messianism." 29 The occupation of the West Bank was seen by many of the religious as the liberation of the territories of the Holy Land and consequently was seen as a miracle. . This profound sense of confidence and hope in redemption in some segments of Israeli society, coupled with the doubts of other segments, brought the entire issue of national definition into the forefront again. The peculiarities of Israel's electoral system has brought the conflict further to a head as religious parties command considerable, and perhaps proportionately unjustified, 
sway in the political arena. I.t is therefore in this ight that the present day struggle over the national identity of Israel must be viewed.

Theoretically, the case of Israel has profound implications for Western theories of nationalism. The inability to understand or seemingly to predict the emergence of secular-religious tensions in the non-Western world and in particular in Israel is not so much an issue of having to explain why religion has entered the political sphere, as one of a misunderstanding of religion itself. The 'sudden' impact of religion on politics in the 1980 s is not new, nor can it be termed as aberrant or Irrational: Nor is religion something that is now opportunely manipulated by political forces for their own gain. Rather it is a logical outgrowth of central religious themes and structures. 30 What is presently happening in Israel in fact should perhaps be viewed as the rule and not the exception. Religion changes and adapts to situations in a continuous cycle; it cannot be viewed, as the West has predominantly done, in a linear fashion with religion receding further in importance and significance as nations-states modernize and develop. The case of Israel demonstrates that the relationship between religion and nationalism must be re-evaluated according to the specifics of both the religion and the history of the nation.

Israel is not deciding whether or not its future shall be a separation or fusion of 'church and staté'. To view the struggle going on now in such a light would be to grossly oversimplify the issue; religion cannot simply be 'replaced' by ethro-nationalism, just as 
nationalism cannot sustain itself in a purely secular form. The 'raison d'etre' of a nation may often require more than an ethnically based nationalism to bind the society and maintain its cohesiveness and loyalty through periods of șelf-questioning.

Theoretically, the case of Israel reflects the 1 inited applícability of Western concepts of nationalism on a global scale. Western scholars of nationalism have attempted to apply their ethno-centric bias of the separation of church and state in interpreting the course of the history of nationalism in the non-Western world. It is for this reason that the rise of the Ayatollah came to the world as a surprise. It is also for this reason that outside observers were shocked by the active political role taken by religious parties and groups in Israel. Dominant theories of nationalism must be re-assessed in terms of the amount of weight and influence religion is given. Religion must be seen as a changing, continuous and vital phenomena in its relationship with national identity.

The aim of this essay therefore is to attempt to understand the present day tensions Israel appears to be experiencing between its religious and secular populations; what this 'batfle' concerns and why it is occurring in a secular democratic state. Based upon a historical analysis, 31 it $w+11$ be argued that Israel is presently undergoing a period of re-defining its national identity; specifically the relationship between the religious and ethnic components. Based upon the Israeli case study, the implications this 'struggle' appears to have for theories of nationalism will then be briefly examined. Chapter two 
will begin by examining Western theortes of nationalism and what role they have traditionaliy attributed to religion in national identities. Having established the theoretical groundwork, chapter three will begin with the case study by looking at Judaism itself, the soorice of identity it provided before the rise of nationalism in Europe and then tracing its subsequent decline as a form of national identity. In chapter four the appearance of Zionism as a Jewish movement of national liberation and most importantly the religious reaction and accommodation, to the Zionist ideology will be examined. Chaptertfive looks at the changes that Labour Zionism experfenced after the creation of the state of Israel, its disintegration as the national identity, and how it was the Six Day War which triggered the present day situation. Finaliy, in chapter six conclusions will be made regarding both the case of Israel and the theoretical body of academic literature concerning nationalism. 


\section{Endnotes}

* 1 Eric Silver, "The 'War of the Jews', "Maclean's, 18 January 1988, 19.

2 The Jerusalem Post International Edition, 27 June 1987.

3 Raphael Patai, The Jewish Mind (New York: Charles Scribner's Sons, 1977), 15.

4 Dan V. Segre, A Crisis of Identity (U.S.A.: Oxford University Press, 1980), 23.

5 Lilly Weissbrod, "Core Values and Revolutionary Change," in The Impact of Gush Emunim, ed. David Newman (Great Britain: Croom Helm Lttd., 1985); 82.

6 Segre, A Crisis of Identity, 23.

7 Ibid., 27.

8 Ibid., 28.

9 Ibid., 21.

10 Weissbrod, "Core Values and Revolutionary Change," 82.

11 Lesley Hazelton, Jerusalem. Jerusalem (U.S.A.: Penguin Books, 1986), 228.

12 Segre, A crisis of Identity, 29.

13 Yigal Elam, "Gush Emunim: A False Messiantsm," Jerusalem luarterly 1 (Fall 1976), 61.

14 Weissbrod, "Core Values and Revolutionary Change," 72.

15 Ibid.

16 Lilly Weissbrod, "Gush Emunim Ideology," Middle Eastern Studies 18 
(July 1982), 271.

17 Jerusalem Post International Edition, 19 December 1987.

18 Ibid.

19 Ibid.

20 Eliezer Goldman, Religious Issues in Israel's Political Life (Israel: Jerusalem Post Press, 1964), 65.

21 Marcus, "War of the Jews," 191.

22 Ibid.

23 Goldman, Religious Issues in Israel, 58.

24 Ibid., 64.

25 Ibid., 55.

26 Marcus, "War of the Jews," 191.

27 Daniel Levine, "Religion and Politics in Comparative and Historical Perspective," Comparative Politics 19 (October 1986), 96.

28 After the establishment of the state, all the various secular school

- systems lead by Zionists streams were united under one state-run educational system; the religious schools on the other hand were placed under the direction of the National Religious Party, free to develop as they wished.

29 Jerusalem Post International Edition, 7 March 1987.

30 Levine, "Religion and Polftics," 96.

31 While this paper will be taking a historical approach, two timeperiods, 1948 to 1967 and 1967 to the present, are dealt with less thoroughiy as it was felt that these represent a further intensification of the trends and changes already established after the creation of the state and the Six Day War respectively rather 
than any new development.

$\$$

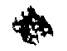




\section{Chapter Two}

\section{The Role of Religion in Theories of Nationalism and Politics}

This chapter will look at theories of nationalism and those of religion and polftics, and essentially ask why it was that Western a socteties had been unprepared for the increase of the role of religion in our political spheres. Why have we thought of religion. as unimportant, unconnected and increasingly marginal to the public sphere? Why has religton not been considered an important enough factor to divide our societies into an 'us' and a 'them'? Why is it that Western theorists have attributed an exceedingly minor role to religion in the formation of national identity? After a survey of the dominant theories that have guided Western thinking, newer theories that have attempted to explain the rise of religion in politics, will be examined.

Despite differences of definition, the West has held a fairly unified view of the historical roots and meaning of nationalism, particularly in terms of its relation to religion. As generally understood today, nationalism first developed at the end of eighteenth

- century Europe, out of the French Revolution's ideals of 'popular sovereignty'. By the mid-nineteenth century, the movement of nationalisnil had been given political expression in the form of nation-states. While it was not necessarily an inevitable step from the concept that the source of political legitimacy rests in the people rather than the divine, it was a short step to the doctrine of self-determination of peoples. ${ }^{1}$ The 'dawn' of the modern age of $A$ is 
nationalism therefore arose only after the 'dusk' of religious modes of thought. While it is not said that the appearance of nationalism is "'produced' by the erosion of religious certainties, ... nor ... that somehow nationalism historically 'supercedes' religion", the development of nationalism in Europe is generally viewed as a form of progress: loyalty, and a sense of identity, previously based upon religion and adherence to the church, had progressed to a new level of secular, ethnically based identity and 'faith'. 2 It is this concept of nationalism; base on the European experience, that Western scholars refer to when speäking of nationalism in a global context.

- Implicit in this view is the assumption that religion is somehow secondary to supposedly more immediate, .'real' or 'rational' social, economic, and political forces. But more importantly, as Levine points out; three further assumption are critical here: the first makes religion ephemeral; the second takes religious motives and groups as less evolved alternatives to politics, at best 'prepolitical' way stations; and, the third assumes inevitable secularization, with religion appearing as a survivor from the past, doomed to privatization and disappearance. ${ }^{3}$ Religion has been regarded as 'abnormal' or 'discontinued' in terms of a modern society. ${ }^{4}$ Consequently, its role and impact on potitics today have been regarded as both alerrant and irrational, regardless of the religion's central themes and structures.

Furthermore, theory tended to view what it saw as the diminishing salience of religious, cleavages as not only inevitable but blso universal. Based upon the experience of one religion, 
Christianity, and in one part of the world, Western theorists applied the logic of secularization across all religions and all nations. This ethnocentrism has obscured not only the individual histories and cultures of nations but also the different structures and logics of each of the monotheistic religions. This is precisely what Bernard Lewis argues in response to the case of Iran and the shock the West experienced over the overythrow of the Shah. The Iranian Revolution, Lewis states, can be regarded as perfectly logical and predictable given the structure and the model Islam provides. 5 Westerners, Lewis continues, tend to view Islam from a Western viewpoint of religion: that is, as "a section or compartment of 1 ife reserved for certain matters, and separate, or at least separable, from other compartments of 1 ife designed to hold other matters." 6 Just as in the case of Judaism, this

- is simply not so. Westerners were consequently surprised as religion 'spilled' into all forms of polttical and social iffe in Iran. Religious themes, structures, and practices have a logic of their own. And, as Levine states, individuals and groups may therefore be governed as much by that logic as by adherence to 'secular' social or political agendas. 7 Religious identity may divide societies as forcefully as other forms of identity. Levine further corroborates Lewis. Analyses which remain within the contours of conventionally defined political events are likely to misread the process. This serves to emphasize the ethnocentrism of Western theories in attempting to apply the logic of Christianity to that of Islam and Judaism. Furthermore, while Christianity máy have undergone a long process of at least partiaf separation between church and state before nationalism developed in 
Western Europe, in the Middle East nationalism, both as a theory and as means for organising society, arrived in its fully developed form with European encroachments and imperialism. States were suddenly carved from lands and peoples whose immediate loyalties lay in their extended families and tribes and whose identity in a major part was undisputedly Islamic. Arab consciousness and eventually nationalism thus developed in the Middle East as a reaction to the intrusion of the West and as a need to defend Islam. It was therefore forced to develop before the 'dusk' of a mentality and a society based upon an Islamic way of thinking. The point therefore is that in applying Weștern theories of nationalism, differences in history and cultures were totally ignored. These differences however inherently precluded the reproduction of the Western example. Finally, theoretical understandings of religion have suffered from being historical. They have applied the experience of one time period to all time. This type of linear view of history can only envision a future similar to the present, if not one further developed in its tendencies. It cannot account for changes in either time or place. Western theories on the role of religion are thus linear, ethnocentric and historical.

Central to an understanding of national identity and the role of religion in both the literature on nationalism and politics, is a definitional overview of exactly what is meant by 'nationalism' and the dominant issues discussed within the field. A brief glance at a few definitions of nationalism quickly inform the reader of the vast scope 
of definitions and meanings that the term nationalism and nation encompass. Funk and Wagnall's for example defines a nation as:

1. A body of persons associated with a particular territory and organized under a government. 2. A body of persogs having a common origin and language and social way of if fe. 8

Hugh Seton-Watson defines it as a "community of people whose members are bound together by a sense of solidarity, a common culture, and a national consciousness." For Foon on the other hand, national identification "refers to citizen's generally positive self-identification as a national of a particular state." 10 According to Connor a nation is a "self-conscious"ll or a "self-differentiating ethnic group".12 Akzin argues that a nation is an ethnic group that has exceeded the purely local dimension and become significant in the political sphere.13 Finally, Anderson states that a nation is "an Imagined political community--and imagited as both inherently limited and sovereign." 14 This 1 ist of definitions reflects not only the ambiguity of the term nationalism, but also the debates that up until recently have raged within the discipline of political science.

Broadly speaking, definitions of 'nation' can be divided into two types, objective and subjective. Objective definitions treat nations as verifiable communities of language and culture. This sort of definition often produces more nations than ever have been or could be in the world. 15 subjective definitions on the other hand, base the notion of a nation on a community of will and consent. 16 However, while taking into account the 'we-feeling' found in national movements, 
subjective definitions when strictly defined, risk to include other self-affirming groups, such as unions, under the heading of nations. Regardless of definition, the thrust of scholarship in the 1970s concerned itself with the question of just what a nation is, particularly in contrast with such terms as ethnic groups and ethnicity, patriotism, loyalty to the state, xenophobia, minority group, tribe and race.

If nations were to have 'grown' or developed out of ethnic groups, how did they do so? In general, writings dealing with the distinction between ethnic groups and nations emphasized two main characteristics: the continuous historical tradition of nations, and the political status of nations. Similariy, the issue of the 'self-awareness' or 'self-consciousness' of ethnic groups and nations was hotly debated. Many scholars just threw their hands up in despair accepting the confusion and ambiguity surrounding the terms. Some even argued for the elimination of the terms ethnicity and ethnic-nationalism a11 together. 17

In addition to searching for an agreed upon meaning and a definition of nationalism and associated terms, scholars have had to ask themselves from where ethnicity and nationalism are derived. Richmond points out that there have generally been two views of understanding ethnicity. 18 One, the 'primordial ' ar 'ascriptive' explanation, views ethnicity as quasi-natural, as a matter of descent, even of socio-biological determinants. 19 The other view insists that ethnicity is situationally defined and may be acquired or divested at w111.20 This 
approach is often called an instrumentalist, 21 optionalist or circumstantialist one, 22 and views an individual's ethnic identity not as a consistently salient phenomenon, but rather as something that can . be "consciously emphasized or deemphasized as the situation dictates." 23 However, if nationalism is derived from ethnicity, the question remains, what 'triggers' it? How and why does an ethnic group become a nation? The point is, whether scholars have espoused a version of the modernization theory, a 'micro-social' theory, 24 a 'biosocial' explanation, 25 a Marxist-Leninist theory, 26 or one of the 'systems theories and multivariate models', 27 the question of religion has remalned conspicuously absent. Religion has not been considered an important factor for debate in any way. Scholars have not challenged the dominant assumptions about the role of religion in modern society that have continued to relegate it to an innocuous role.

When one surveys the literature on nationalism, the most predominant attitude towards religion regards religion as simply one more 'trait' or 'marker' or characteristic, similar to language, race or cultural habits, that distinguish one nation from another. Armstrong for example, adopting F. Barth's approach, argues that 'markers' such as religion, language, customs, institutions, music, art, food, dress, colour, and even territory "may change in content over time, or even fall away completely and lose their meaning, ... but some other marker must replace them, some new symbol of exclusion and visibility." 28 None therefore, according to Armstrong, possesses an intrinsic difference; all markers are substitutable. Connor agrees and argues

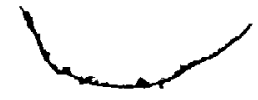


against those scholars who refer to the problem in Northern Ireland as one of religion; to do so Connor feels is the "result of mistaking the tangible manifestations of the nation for its psychological essence." 29 Similarly Connor argues that a nation can alter or lose any or all of its outward characteristics (e.g. religion) without losing the sense of vital uniqueness which makes it a nation.

The other common theme is for scholars to esteem religion as a useful 'phase' in nationalism which serves to mobilise the population. Seton Watson for example states that religion has played an important part in the development of national consciousness where the rulers and the ruled have been of a different faith. In these cases it was religion. which became the basis for the nationalists' initial sense of distinctivemess. According to Seton-Watson, "before long these movements based on religion split up, as the secular category of language became more important." 30 Again differences in religion are treated as unimportant or of essentially diminishing or transitional impact.

Yet has ethno-national identity 'replaced' religion as the primary source of identity? Is religion no longer capable of creating cleavages, cleavages for example that create and distinguish national identities? Why is it that religion is no longer thought of as something that can divide our modern societies and move people or groups to action? Why should religion be thought of as different from any other cleavage within society? Religious adherence involves the same 'us' versus 'them' feeling as any other divisions within soctety; and 
this includes both internal cleavages within the group itself and external, between the group and the 'outside world'. Looking at the case of Israel for example, cleavage 1 ines exist both between the religious and secular forces as well as within the religious 'camp' over disagreement on how to deal or react to Zionism. Religious cleavages arise between the believer and the non-believer. Further divisions occur over strictness of interpretation or adherence. Charles Liebman, for example, basing himself on Judaism, argues that religious groups differ over the scope, detail and strictness of religious law, the degree of social isolation, and the rejection of the surrounding. culture. 31 In all instances the degree of 'extremism' is dependent upon the religious group's relation to the non-religious environment, or the perception of the non-religious environment. 32 Thus religious groups and parties differ as to the degree they 'mix' or associate in the modern Israeli society as well as the degree to which they cooperate or 'collaborate' with the Zionist movement and today's secular parties. Does one isolate oneself and maintain the 'purity' of the religion or does one enter the 'world' of the non-religious in order to hopefully effect some change there? Historically this seems to hold true since religion has acted as both a political activator as well. as a pacifier depending on its relationship with the political powers that be: Throughout time there have been periods of antagonism, acrimony, conflict as well as collusion, partnership and cooperation between politics and religion. The point is that when inserted into the political. sphere, religion behaves no differently than any other cleavage within society, may it be class or ideology. Yet why has 
religion been treated as it has? Why is it that Western society has been shocked by the power of religion to so cleave society along national issues as to enter if not determine its political sphere?

Panikkar for one argues that the West's inability to comprehend the relationship between religion and politics in general stems from the following attitude in the West: "either religion and politics are considered identical (Caesaro-papism, theocracy, 'sacrum imperium' and all types of totalitariánisms), or else one is pitted against the other as if religion and politics were mutually incompatible and antagonistic forces (Church and state, sacred an secular, God and Caesar and all types of liberalisms)".33 In other words, Panikkar hypothesizes that the problem of the relationship between politics and religion is one of the "monism/dualism" dilemma of Western civiltzation. 34 Politics, Panikkar argues, is the art of means and ways for the realization of a human order. Order is the integration of each part into the whole. Religion on the other hand is the art of the means and ways for the realization of the ultimate order. 35 Therefore, all burning religious issues are at the same time political; similarly all important political issues are at the same time religious. There is a nondualistic relationship between the two and this is what, according to Pannikar, Western scholars fail to pérceive. $36^{\circ}$

If this is the case, where then do the roots of this 'dilemma' lie in Western scholarship? How have Western society and theorists come to regard religious cleavages as so unimportant? Why has religion been supposedly subsumed by nationalism? .Robertson for example, broadly 
agreeing with Bellah, argues "that the 'liberal', ethos which prevailed in Anglo-American intellectual contexts for much of the nineteenth and twentieth century perfod blinded many analysts" to the likelihood of 'church-state' tensions across the globe $37^{-1}$ It may be said, Robertson goes on to explain,

that under the sway of 'liberal progressivism' which grew rapidly with the professionalization of "the social" sciences, it was widely assumed within the academy and among political elites that an increasing number of--and potentially al1--societies would be able to function individualiy and 'progress' in terms of relatively latent national identities, and that cultural traditions at the national level or sub-national levels would recede to the point of assuming almost onty cosmetic significance or, at most, modes of almost-entirely 'internal' connecting of individuals to their respective societies. Moreover, in that scenario religion as an aspect of either collective-societal or individual life was regarded as, at best, marginal. 38

The Western attitude towards religion may also be explained by what Almond and Verba term the rise of a 'civic culture'. A civic culture is "not a modern culture, but one that combines modernity with tradition." 39 It is the rise of such a culture that facilitated the secularization of Western society in a peaceful and relatively unproblematic way; without the disintegration or polarisation of soclety. Almond and Verba demonstrate how Britain offers an example of how such a civic culture'can develop. The key was the "emergence of a thriving and self-confident merchant class, and the involvement of court and aristocracy in the risks and calculations of trade and commerce." 40 These were the forces that enabled Britain to pass through the era of 
absolutism and feudal estates into that of a parliamentary tradition and pluralism without any sharp discontinuities.

The aristocratic Whigs found it possible to enter a coalition with nonconformist merchants and industrialists, to establish securely the principles of parliamentary supremacy and representation. The traditional aristocratic and monarchic forces assimilated enough of this civic culture to compete with the secularist tendencies for popular support and, indeed, to mitigate their rationalism and impart to them a love and respect for the sacregness of the nation and its ancient institutions.

Thus a third culture emerged, with netther a wholly modern nor wholly traditional attitude, that enabled Western societies to adapt to new circumstances. New attitudes merged with old ones. It is this. civic culture therefore which is seen as the key or 'link' behind the secularization of our Western societies; that which enabled our societies to 'forgo' religion as an important source of identity and therefore division or cleavage within societies. Religion, according to this theory, simply did not have any functional role to play and therefore became increasingly marginalized as secular modern societies developed. As the technology of the industrial revotution advanced upon England for example, religion was not fundtional in the integration of technology into society and therefore is seen to have not played a divisive role since the industrial revolution.

It was thus that discussions of religious cleavages and the ir importance became less sallent in soctety. It is also how one can begin to explain the dominance of theories of secularization throughout the last twenty to thirty years in Western academia. Secularization theory 
is essentially the dominant Western theory that has determined the secularization or decline of religion as societies progress. In other words, secularization theories predict not only the eventual irrelevance of religion in the political sphere but the incapability of religion to shape or move our societies in any way. It is actually a part or an aspect of the general phenemena known as political modernization. 41 While disagreement occurs concerning the exact definition of political modernization, three major themes or processes may be identified as running through the majority of definitions: differentiation, equality, and, Epactity. ${ }^{42}$<smiles>CCCCC</smiles>

Systems undergoing modernization become more differentiated in terms of governmental and political structures, place increasing emphasis on the equality of citizens in political participation and the al location of benefits, and increase their capacity to bring about socioeconomic change. 43

Secularization therefore refers in particular to the first aspect of modernization and is the process in which "... religious interpretations of reality and religious orientations, toward life [are displaced] by an orientation that seeks explanations for and justifications of human behavior and other phenomena in scientific and rational terms." 44

According to Jose Casanova, secularization theories can be divided into three approaches or positions. 45 The first position, represented by Bryan WIIson and Peter Berger, argues that the decline of traditional religion and the loss of its social relevance occurs inevitably together with the process of modernization. 46 Both basically 
argue that this decline is due to a process of 'functional differentiation' or 'Societalization'; 47 in other words, "it is not that the ideas or values of religion have necessarfly become less important, but that there is increasing competition among ideas, values, and religious systems." 48 The second approach Casanova maps out is best represented by Greeley. 49 While Greeley does question the implication that the process of secularization spells the end of church religiosity and the emergence of 'secular man' or the soctal irrelevance of religion, he too does not question the institutional differentiation of secular spheres nor the dominance of these spheres in modern society. 50

The third approach is that of the 'fuñctionalist' thesis: religion in the modern world does not disappear, it is merely transformed. The two scholars most associated with this position are Luckmann and Bellah. 51 According to functionalist theory, reilgion is defined "as the institution that creates and recreates the normative consensus and the feeling of solidarity that supposedly hold any soclety together".52 Religion therefore, according to this school, cannot disappear without bringing the society also down in its wake. 53 If religion is declining and society is not disintegrating, then social scientysts can only adopt a new definition or conclude that a new form of religion has displaced the old. 54 Luckman therefore argues that today the

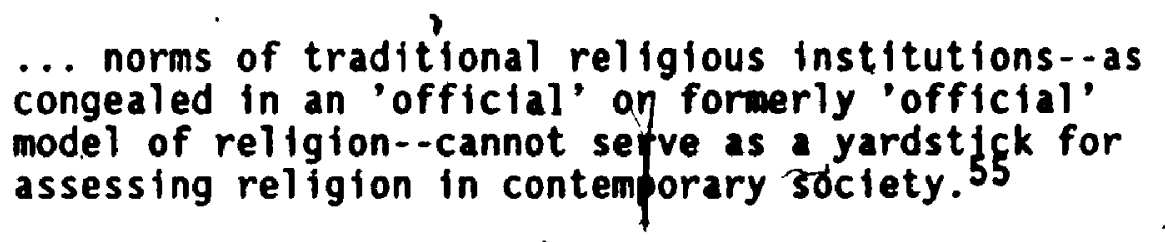


Describing it as an 'invisible religion' or an 'institutionally non-specialized social form of religion", Luckmann argues that religion has increasingly become one of a private affirir. 56 similarly, Bellah, taking a societal perspective rather than one of the individual as Luckmann does, argues that religion has been 'transformed' into what he calls 'civil religion'. Like Luckmann, Bellah also belleves that any analysis that concentrates on church religiosity misses the true nature of modern religion. 57 Although, according to Bellah, "traditional religlous symbolisms may persist, each man is ultimately responsible for the choice of his symbolism or for the personal appropriation, of traditional symbolisms. "58 Modern secial structures, Bellah continues, are the institutionalized expressidn of these religious values. 59 Belfah thus sees societal structures as functionally integrated into one meaningful system. 60 Civil religion is the "collective system of ultimate symbols [that] integrate social structure; culture and personality into a meaningful whole." 61 The civil religion or symbols therefore change from society to society.

Dobbelaere, in her review of theories of secularization, also typifies the literature into three different themes, albeit different ones from Casanova: Individual analyses, societal and organizational. Under those scholars emphasizing the individual and secularization Dobbelaere notes Luckmann and Martin. Wilson and Luhmann are cited as the most prominant theorists dealing with secularization as a process of societal change. And Dobbelaere looks at $D$. Martin as representative of those scholars investigating religigus changes at the organizational 
level such as denominational changes. While all of the above mentioned' theorists approach secularization from different levels of analysis and offer different explanations, none reject the process of secularization and the assumption of the inevitable ineffectiveness of religion as an actor in society.

.With the rise of 'church-state' tensions throughout the globe however, social scientists have begun questioning the validity of their theoretical predictions. Society it seemed was incapable of compleţe secularization; some 'link' or explanation appeared to be necessary for the very purpose or 'raison d'etre' of soclety. Religion was proving to divide and. 'move' societies once again. Sécular nationalism seemed in many cases unable to provide the meaning and purpose that individuals and nations required. Or rather it could not supply the all inclustre identity it was deemed to be able to provide. 'It is out of this exact coneern or realization for example that interest developed in debates concerning theories of civil.religion. Essentially, the thrust of civil religion had "to do with the overcoming of perceived deficiencies concerning such linkages as religion-state, religion-politics and individual-society. $" 62$

Social scientists began asking whether or not secularization could be regarded as the straight forward mechanical process they. once thought it was. Dobbelaere for example notes that in Europe religion fought back against secularization by a process she calls 'pillarization'.63'Pillarization is the process in which organizations were founded and run by comnitted church members to provide a varlety of s) 
social functions. These organizations are centralized in 'pillars', (for example, the Catholic pillar in Belgium), and encompass schools, hospitals, old age homes, youth movements, welfare organizations, newspapers, and libraries. The Catholic pillar in Belgium, for example, a) so has a federation of sick funds, a trade union and a political party, the Christian People's Party (although now non-denominational). These "pillarized structures", according to Dobbelaere, were designed and developed to protect believers from secularization; and most of them in Europe did 'survive' the crisis in the Church of the late 1960s and 1970 s. 64

As secular-ethno-nationalism therefore was found to be wanting in terms of its ability to provide a single source of cohesion for its citizens, theories began to focus on the question of national identity as a means for understanding the 'ney' divisions and tensions within societies. Robertson for example argues that societies' re-evaluation of religion is primarily due to a problem of external and consequently internal legitimation. 65 What seems to have happened, according to Robertson,

is that the rapidiy increasing and multifaceted nature of interdependence at the global level, accompanied by an increase in embryonically-institutionalized rhetoric concerning universal standards applicable to all nations and individual members of nations, has accentuated the problem of external legitimation of contemporary societies. 66

The result has been an increasing focus on the values of society and as Robertson states what societies 'really stand for'. Newly-formed - religious movements are therefore a manifestation of this phenomenon as 
they are directly concerned with the reconstruction of values: 67 The conflict becomes one of a national identity.

Similarly, Bourg feels that the relationship between religion and politics is all part of a "basic dilemma of our time, a dilemma ... [called] pluralization versus privatization."68 Pluralization involves the increased publicization of previousty private matters as issues central to the public good. One example would be the pursuit of civil rights for various categories of persons. 69 The other 'horn of the dilemma' according to Bourg is the privatization of public matters; when public affairs get privatized or when matters that may have begun as private interests are prevented from their making a contribution to the public agenda. 70 As the question of pluralization versus privatization confronts both politics and religion, Bourg argues, it therefore effects the relatyions between them. In politics for example, the greater pluralization of political actors has resulted in a multiplication of groups that have taken activist roles in pursuing political objectives. For religion, pluralization has meant the recognition of greater diversity of opinion and action among its members and among persons speaking in the name of religion. 71

As society becomes increasingly complex, there is a general loss of confidence that public offictals know what they should do or that they are capable of resolving problems. This in turn augments the number of persons and groups trying to take matters into their own hands. Looking at the United States, Bourg thus argues that the United States' extreme difficulty in agreeing upon what polictes and programs 
contribute to the public interest, reflects the fact that the American people are presently being challenged to foster a new collective identity. Three issues according to Bourg will most clearly demonstrate this challenge: 1) the relatively new focus on war/peace due to build-up of nuclear power; 2) exhaustion of nonrenewable sources of energy; and,

3) unemployment; technology. 72 It is in these three issues that the church will become increasingly involved as they touch upon the questions of 1 ife and death and conditions of humanity most relevant to religion; in others, what society is to stand for.

This is corroberated by Cochran, Perkins and Havens whose research on public policy and the emergence of religfous politics concluded that recent church-state controversies are to a large part due to the fact that governments increasingly regulate those activities in which the church has a direct interest. These are namely: 1) church-state issues of which the question of school prayer and the taxation of churches would be an example; 2) questions of personal morality, such as pornography, gambling and homosexual rights; and, 3) issues of peace and justice, for example racial and sexual equality as well as foretgn aid, nuclear deterrence and policies in the Third World. 73

- Regardless of the issue, religion has proven to be a dynamic source of cleavage, a source of 'us' versus 'them' within our societies today. Furthermore it is a source that is directly involved in the values, the meaning or purpose of our societies: our national identities. Nationalism did not simply replace religion as the source 
of identity within societies. Religion has hot simply receded or even 'died out' in terms of its ability to divide paople and move them. It is not a matter of religion declining or resurging in gross terms, but rather one of a restructuring between the two elements.

Ethnic-nationalism and religion are intimately and inextricably bound together. It is in the process of this reformulation of the relationship between the two that religion has entered the political sphere. The ethno-centricity of theories of nationalism as well as their linear view of history have prevented Western societies from $\because \quad$ recognizing the importance of religion as a shaper of national identity and consequently its ability to divide societies to such a degree that it may lead to political tension or even violence. As the case study will demonstrate, Israel is undergoing exactly such a restructuring of the relationship between the religious and ethnic components of $t$ ts national identity. 
Endnotes

1 Walker Connor, "The Politics of Ethnonationalism," Journal of International Affairs 27 (1973), 5.

2 Benedict Anderson, Imagined Communities (London: Verso Publishers, 1983), 19.

3 Daniel Levine, "Religion and Politics in Comparative and Historical Perspective," Comparative Politics 19 (October 1986), 95.

4 Ibid., 96 ,

5 Bernard Lewis, "Islamic Revoluthon," The New York Review 21 January 1988, 46.

6 Inid.

7 Levine, "Religion and Politics," 96.

- 8 Funk and Wagnall Standard Dictionacy, 1980 ed., s.v. "nation."

9 Konstantin Symmons-Symonolewicz, "The Concept of Nationhood: Toward a Theoretical Clarification, " Canadian Review of Studies in Nationalism (Fall 1985), 216.

10 Chew Sock Foon, the Incompatibility of Ethnic and Nationat Loyalties: Reframing the Issue, "Canadian Review of Studies in Nationalism 13 (Spring 1986), 2.

11 Connor, "Politics of Ethnonationalism," 3.

12 Walker Connor, "Nation-Building or Nation-Destroying?, "World Politics 24 (Aprit 1972), 337.

13 Symonms-Symonolewicz, "Concept of Nationhood," 219.

14 Anderson, Imagined Communities, 15. 
15 Anthony Smith, "Ethnic Myths and Ethnic Revivals," Archives Europeennes de Soctologie 25 (1984), 290.

16 Ibid.

17 Louis L. Snyder, "National ism and the Flawed Concept of Ethnicity," Canadian Review of Studies in Nationalism 10 (Fall 1983), 263.

18 Anthony Richmond, "Ethnic Nationalism: Social Science Paradigms," International Social Sclence Journal 111 (February 1987), 3.

19 Smith, "Ethnic Myths and Ethnic Revivals," 285.

20 Richmond, "Ethnic National isms," 3.

21 Smith, "Ethnic Myths and Ethnic Revivals," 285.

22 Foon, "Incompatibility of Ethnic and National Loyalties," 1.

$23^{\circ}$ Ibid., 2 .

24 Richmond, "Ethnic Nationalisms," 11.

25 Ibid., 5 .

26 Ibid., 8.

27 Ibid., 12 .

28 Smith, "Ethnic Myths and Ethnic Revivals," 285-286.

29 Walker Connor, "A Nation is a Nation, is a State, is an Ethnic Group is a ...," Ethnic and Racial Studies 1 (October 1978), 389.

30 Hugh Seton-Watson, Nationalism--0ld and New (Australia: Sydney University Press, 1967), 9.

31 Charles Liebman, "Extremism as a Religious Norm," Journal for the Scientific Study of Religion 22 (March 1983), 75.

32 Ibid.

33 Raimundo Panikkar, "Religion or Politics: The Western Ditema," in Religion and Politics in the Modern World, ed. Peter H. Merkl 
and Ninfan Smart (U.S.A.: New York University,. 1983), 44.

34 Ibid.

35 Ibid., 45.

36 Ibid., 46.

37 Ronald Robertson, "Considerations From Within the American , Context on the Significance of Church-State Tension," Sociological Analysis 2 (Fal1 1981), 196.

38 Ibid., $195-196$.

39 Gabriel Almond and Sydney Verba, Civic Culture (U.S.A.: Little, Brown and Company, 1965), 5.

40 Ibid.

41 Ibid., 5-6.

42 Donald Eugene Smith, Religion and Political Modernization (U.S.A.: Yale University Press, 1974), 4.

43 Ibid., $4-5$.

$\Rightarrow$ 44. Ronald L. Johnstone, Religion in Society (U.S.A.: Prentice-Hall Inc., 1983), 270 .

45 Jose Casanova, "The Pofitics of the Religious Revival," IELOS 59 (Spring 1984), 6 .

46 Ibid.

47 Karel Dobbelaere, "Some Trends in European Sociology of Religion: The Secularization Debate," Seciological Analysis 48 (Sumner 1987), 113.

48. Johnstone, Religion, in Society, 273.

49 Casanova, "Politics of Religious Revival," 7.

50 Ibid. 
51 Ibid., 9.

52 Ibid.

53 Ibid.

54 Ibid.

55 Johnstone, Religion in Societ.y, 332.

56 Dobbelaere, "Trends in European Sociology," 111.

57 Casanova, "Politics of Religious Revival," 13.

58 Ibid., 14.

59 Ibid.

60 Ibid.

61 Ibid.

62 Robertson, "Considerations, , 195.

63 Dobbelaere, "Trends in European Sociology," 128.

- 64. Ibid.

65 Robertson, "Considerations," 197.

$\therefore 66$ Ibid.

67 Ibid.

68 Carroll J. Bourg, "Politics and Religion," Sociolagical Analysis 41. (Winter 1980), 297.

69 Ibid., 298.

- 70 Ibid.

$71^{+}$Ibid.

72 Ibid., 304.

$73 \mathrm{Clarke} E$. Cochran, Jerry D. Perkins, and Murray Clark Havens, "Public Policy and the Emergence of Religious Politics," Puble Policy 35 (Fall 1987), 600-601. 


\section{Chapter Three}

\section{Jewish Nationheed and the Rise of Nation-States:}

\section{A crisis of National Identity}

This chapter will examine the importance of religion in the formation of national identities prior to the Enlightenment. In. particular it will delve into the national element.inherent in Judaism that was to be in direct conflict with the new secular concept of ethno-nationalism. With the consequent emergence of the new 'emancipated' and 'secular' Jew, the failure of even assimilated Jews to escape persecution at the end of the nineteenth century triggered the inevitable identity crisis.

With the creation of nation-states in the nineteenth century, European Jewry was to undergo the most profound crisis of identity it had thus far experienced in its national history. In what can be termed a mass conversion, thoursands of Jews were to leake traditional Judaism and the ghettos and enter the surrounding Gentile population as Christians. The Enlightenment the Rousseauan concept of 'la patrie' had swept across Europe bringing with it the problem of "nationalism, or more precisely, national integration" the likes of which had never before been encountered. 1

A movement of 18 th century intellectuals, the Enlightenment "represents the efforts of Western mankind to apply the rule of reason to all phases of human 1 ife." 2 It was believed that it was only through the application of reason that man could attempt to understand the 
meaning of the universe, to remould his world and free himself from the bondage of ignorance and superstition. ${ }^{3}$ In particular, the Enlightenment's reverence for reason reflected a rejection of religion with its corruption, wars and inequities. Intellectuals of the Enlightenment wanted 'clean', rational, non-superstitious religion and argued that "beneath the world's religious diversities, there was a common body of beliefs, a religion planted by nature in all men everywhere." 4 The goals of this new 'rational man' therefore became knowledge, freedom, and happiness. ${ }^{5}$ Politically and socially this meant that the followers of the Enlightenment were "opposed [to] every form of intolerance and absolutism, and demanded freedom and equality for all." 6 Beginning in Northern Europe, the philosophy of the Enlightenment was thus to culminate in the form of the French Revolution which is seen as marking the beginning of the rise of nation-states throughout Europe.

3 At the outbreak of the French Revolution there were approximately two million Jews in Europe. ${ }^{7}$ While conditions naturally did vary across the continent, European Jewry could be divided basicd y into two 'regions'. One-tenth of the Jewish people lived fn the highly developed mercantile countries of Western Europe: England, Holland, France and Italy. ${ }^{8}$ Included with these Jews were also the approximately quarter of a million Jews of the slightly less efonomically developed countries of Germany, Bohemia, Moravia, Austria and Hungary. 9 The bulk of European Jewrye however, one and a quarter million Jews, lived in the "backward feudal, agrarian countries of Eastern Europe". 10 Given the, geographic distances and the differences in their economies, conditions 
as well as contact.with the Gentile populations, the Enlightenment and its consequences were to spread to the Jews of Eastern and Western Europe at different times and at different rates. (While the ideals of the Enlightenment were taking hold in the West, Jews of Eastern Europes were turning to the religious movement of Hassidism.) Wrile these differences must be kept it mind, it cannot be forgotten that communication and connections between Eastern and Western European Jewry were strong and that one could not go unaffected by the ideas and political struggles of the other. Nevertheless, while the ideals of the Enlightenment penetrated Eastern Europe at a much later date in the nineteenth century, it was here that the Zionist movement first took hold. Western European Jewry held much more conviction in the beliefs of the Enlightenment; that in these new rational states a person could be a Jew at home and be accepted as an equal German for example in the streets. Furthermore these states possessed a capitalistic economic structure in which the Jew could enter and take part in the new emancipated lifestyle. It was only later, when even those Jews who had converted to Christianity were to suffer from anti-semitic discrimination that Zionism received much greater support in Western Europe. Eastern European Jewry on the other hand, only just slowly entering capitalism, felt few benefits from the 'enlightened' idear3. Afflicted with poverty, influenced by the revolutionary discontent occurring around them and suffering from renewed persecution en masse, it was here that the impetus for Zionism.took hold. 


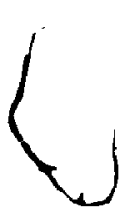

3

- Prior to the Enlightement and the subsequent Jewish

Emancipation, the Jews had lived for more than two milleninium in a state of dispersion, as minorities among greater populations. In all the various diasporas the question of whether or not the Jews belonged to the same nation as the majority population had never arisen. It did not and could not for two reasons. 11 first of all because the entire concept of nationhood, of a people being tied together along ethntc lines, as it developed with the French Revulution, was new. Secondly, the population of Europe's Middle Ages was divided into various estates (or fiefdoms) and not as of yet into nation states, each of which with its own specific corporate status. The

numerous smałl units--feudal domains, towns, ducal and Church states--were all characterized by isolation, provincialism, and mutual competitivism, not to mention the differences and tensions among the estates? such as the nobles, the burghers, vileins, the serfs or peasants, and the clergy, which co-existed side by side in the same territorial unit but were separated and lined up against one another by disparate traditions and clashing interests. these cincumstances, it was taken for granted by both Gentiles and Jews that the Jew constituted a separate corporate body, since evjgently they belonged to none of the other sociat aggregates. 12

Forming what could be termed a "state within state" the Jewish.

communities therefore were not only self-supporting, but they

administered their own affairs, appointed their own.judges and supported their own political institutions: 13

Most important was the difference in religion. Their "Jewishness created a much greater gulf beitween the Jelws and the Gentile population groups than differences in estate ever could between Gentiles 

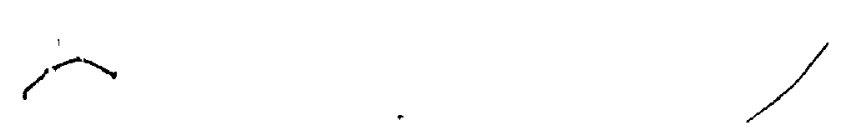

48

themselves." 14 European society, prior to the Enlightenment, was

constructed as a hierarchical system with the various estates and towns

owing allegiance to greater lords and ultimately to a variety of princes

- and kings. Authdejty in these hierarchical societies remained solely and strictly Divinely ordained. Europe was conceived of as being one large church-state called Christendom. 15 Membership whether individual or national, was signalled by one's Christianity. The Jews were thus perceived of as outside the divinely ordained society.

This religious and national differentiation went hand in hand with differences in dress, language and customs that further segregated the Jew from the non-Jewish environment. Firstly, beginning in approximately the fifteenth century when the ghetto had become the legal dwelling place of the Jews, Jews were restricted to certain streets by government ordinances and thus lived in separate neighbourhoods or ghettos. And even in the larger cities where segregational policies were losing their hold, Jews concentrated around their communal - institutions such as the synagogue, reflecting "in their spontaneous emergence, Jewish segregative tendencies." 16 In Eastern Europe, most of the Jews 1ived in 'sh'tetls', small townlets or regional market centres, most of which were predominately Jewish. Living the strictly orthodox lives of their forefathers, many of these centres were exceedingly poor and often could be compared to slums. 17 secondly, the outward appearance of the Jew differed from that of the Gentile. For instance, there was the man's traditional beard and sidelocks. A third distinctive difference was language. Yiddish was spoken by European Jewry of this 
period, and each country and locality had its own dialect. The Jewish population therefore communicated in a language different from that of their neighbours and thereby created a further barrier. Furthermore the differences in the religion itself set the pattern for an entirely different way of life than the Gentile population. While these differences do explain what had set the Jew apart, they do not in of themselves necessarily explain what it was that bound the Jewish community together as a whole, what created a nation out of a people; a nation, the identity of which was to be threatened by the development of nation-states.

Judaism it must be remembered is "not only a religious faith but a comprehensive way of life, with values and a logic of its own..." 18 Vudaism contains the concept of peoplehood, of a people bound together by belief, ritual and history; of a people with a particular destiny and tied, to a particular land. No real understanding of the importance of peoplehood and the land of Israel in Judaism, both traditionally and in present times, can therefore be achieved, without an appreclation of the meaning of the Covenant. For the Mosaic Covenant represents a pact or a promise between God and the Israelites; more specifically it involves a national charge upon the Jewish people to be "a kingdom of priests and a holy nation" (Exodus 19:6) in return for the promise of a land. Jewish national identity therefore "does not depend on time or territory but . upon a certain idea of God--as an active presence in history--and of a people linked by a formal treaty, the eovenant, to this manifestation of the Divine."19 It is this special relationship between Israel and God 
itself therefore which "not only ... [created] and [differenciated] Israel, but also ... [maintained] its unity and corporate identity even in perfods of wandering and dispersal."20 In addition to the actual promise, it must be remembered that it was to a specific group, the Israelites, and their children and their children's children that this Covenant was made. Strictly speaking in contrast to other monotheistic faiths, one is a Jew because of a fact of birth or descent. This is the basis for a distinct feeling amongst the Jewish people of 'belongingness', of 'we-ness'; of a nation.

Furthermore, despite their geographical dispersion, the "Jews were kept together by their adhesion to a common set of. Paws and values." 21 The halakha, traditional Jewish observance, established a pattern of life for the Jew that essentially remained the same regardless of time or place.

No matter where they lived nor what languages they spoke, the pattern of their lives was in essentials the same. A Jew from the most distant part of the world arriving in a strange city would find in the Jewish quarter a way of life. which was essentially identical with his own: not merely the same belief but the same ceremontes, the same religious services, the same. intellectual interests, the same outlook. This reinforced Jewish unity; .... The oneness of the Jewish people was not merely religious or merely racial, but was based on an jdentical historic experience and pattern of $11 \mathrm{fe} .22$

It was the belief in the destiny of the Jewish nation and the promise of land as well as the centuries of diasporic life that helped to develop a third factor which was to bind the Jewish people into a nation. This was the belief in messianism. What had prevented the Jews 
from giving in to conversion and assimilation during their centuries of exile and persecution had been "the unswerving certainty that in due course their. sufferings--as a people, not merely as individuals--would end, and that they would be restored to their former 1 and." 23 Underneath the theological doctrines and mystical extensions, the fundamental belief of messianism was very simple:

that in God's good time, and in the not-too-distant future, conditions would change drastically for the better and a happy state of affairs would be established on earth for Israel--and for the rest of believing mankind, if they gave up their evil ways. 24

Thus historian Maurice Samuel is certainly correct when he writes that the Jews dwelt not in Europe, but in their dreams. They

lived 'in the holy land', either in the distant past or in the Messianic future. Their festivals were tied to the Palestinian climate and ancient Hebrew calendar. Though in the middle of Russia or Poland, in their hearts they were residents of an imaginary Jerusalem. Dafly they repeated the anclent prayer: 'I believe with all my heart in the coming of the Messiah; and exen as he delays neverthless I expect him every day. 25

In a world drawn primarily along reifigious lines, the Jews felt themselves not only to be of a different religion but to be a separate and distinct nation based upon that religion. comunal identity throughout the Middle Ages until approximately the eighteenth century was represented by religious adherence, in no other European religion was the concept of a peoplehood so inextricably bound together. Through the giving of the Covenant the Jews were charged with a national destiny that not only differentiated them from others but provided this nation with a unique history and a specific vision of the future. It/was this 
element of nationhood that was challenged by the national movements and consequently created a crisis of national identity for the Jewislopeople in the new nation-states.

It was therefore a "common religion, nationhood, and messianic hope ... [that formed] the bonds that [united] the Jewish people in the various countries to which they were displaced." 26 It was Judaism which separated the Jews from the Gentiles in a way that no other factor could and bound the Jews together through not only belief but also the practice of a rigorous religious way of 1 ife and through a sense of history and of the future. It was the Jewish religion which not only gave meaning to the individual's life, but also to the functioning of the community and the cohesion of the people. Jewish religious identity outwardly rested on the practice of the halakha. To neglect the halakha was to no longer be a Jew. Without Jewish practice there was no Jew. Faith could not be separated from practice and neither of the two could be separated from nationality. The Jews lived "the highly traditional, rigidly orthodox, closely knit life of their forebears", cut off from their surrounding environment: an "island culture." 27

Al) this was suddenly changed by the Enlightenment. The Rousseauan concept of "the necessity of supreme loyalty to 'la patrie', the fatherland" 28 swept across Europe leaving tremendous social and political upheaval in its wake. With its most notable impact in the form of the French Revolution, soon the concept

that all people who lived within the confines of an independent sovereign state constituted, or ought to. 
consitute, one nation sharing all duties and privileges as citizens equal before the law, was enthusiastically embraced by more and more statesmen. 29

Europe came to be divided into centrally organised nation-states. Gone were the estates of the Middle Ages. Most importantly, the prominence that religion had held as a source of identity as well as a means for understanding the world also came to an end. Self- and group-Identity were no longer to be based on religion but on ethnically determined nationality. Citizenry and the state assumed the prime foci of loyaltyand identity. Thus Enlightened Christians came to see themselves as primarily Frenchmen but of the Christian faith for example. The same was expected of the Jews. The Jews who up to now had been percelved of as a separate and distinct nation were suddenly regarded as a religious community. As Christians firmly placed the state apart and ahead of the Church, so too were the Jews expected to do so.

The Jews therefore simply could not remain as a distinct. corporate body within the state. In the first place it was unacceptable in terms of the rational and egalitarian values of the Enlightenment for the Jews not to share in the equal rights and duties of the nation state. Far more important was that the

modern state, particularly the democratic state, could be established only after the abolition of the corporate distinctions and by the substitution of the egalitarian for the corporate structure of society. To leave the Jewish group as a corporate body apart, endowed with a specific system of rights and duties, had become an outright anachronism. ${ }^{30}$

Thus it was most logical that in France the movement for granting equal rights to Jews would begin. The beginning of the 
emancipation of the Jews is generally marked in 1791 when the French National Assembly firmly established the 'enlightened' principles of equality and religious toleration by bestowing full citizen rights upon its Jewish subjects. This same principle Napoleon appl fed in practically all the lands he conquered until one by one Jewish emancipation had been achieved across mach of Europe. For the first time the 'gates were open' for the Jews to leave the ghet to without having to abandon their faith. In return however, the Jews were expected to become fully integrated into the political, socio-economic, and cultural structure of the surrounding non-Jewish environment. It is this ultimate demand for assimilation whiç is precisely the significance of the meeting of the Assembly of Jewish Notables and the Grand Sanhedrin in Paris in 1806 and 1807.31 The rabbis of the Napoleonic Empire were summoned by Napoleon to define once and for all the nature of wudaism. Complying 'with the Emperor's list of questions and wishes, both the Assembly and the Sanhedrin resoived that

(1) polygamy was ... forbidden to Jews; (2) Jewish divorce was only valid if it followed civil divbrce; (3) Jewish marriage had to be preceded by civil marriage; (4) marriages between Jews and Christians were valid $\ldots$; (5) every Israelite must consider his non-Jewish fellow citizens as brothers and aid, protect, and love them as though they were co-religionists; (6) the Israelite was required to corisider the land of his birth or adoption as his fatherland and had to obey its laws, love it, and defend it when called upon; (7) Judaism did not forbid any handicraft or occupation; (8) it was commendable for Israelites to engage in agriculture, manual labour, and the arts as their ancestors in Palestine were wont to do; and (9) Israeljites were forbidden to exact usury from either Jew or Christian. 32 
The point is that for the first time in their history," "the Jews not only were told by the state what overall, general attitude they were expected to have toward $1 t$, but were required to enter into a solemm undertaking to fulfilil these expectations. More importantly, they were told to love 'la patrie' and their non-Jewish fellow citizens." 33 Pressures were therefore not only exerted upon the Jews to change their attitude toward the outside world, but their entire individual and collective ldfestyle; the only pattern of living they had thus far known. With the newly created regimes "pursuing mercantilist policies in the economic sphere and centralistic ones in the political and administrative spheres", this pressure often resulted in direct interference by the state in the affairs of the Jewish communities. 34 . Furthermore, as changes were rapidly occuring in the 'outside world', this lead to a demand for 'enlightened' changes from within the Jewish communities themselves.

Pressures for change were therefore exerted on the Jewish communities both externally and internally. Externally the newly founded states, centrally directing all polftical and economic-control, were actively breaking down the barriers that had previously separated the self-contained Jewish world. Beginning early in the 18th century, the state for example started to interfere in the previously autonomous internal government of the 'kehilla' (comunity) and the 'super-kehilla'. The legitimacy of the newly established nation-states required that the rulers excercise some form of control over Jewtsh communal affairs. Thus, that the communities paid their taxes and 
obeyed the laws of the state, was no longer sufficient. That the Jews remafined a 'state within a state' was no longer acceptable. The state had to become involved in the internal financlal and organisational management of the communities. 35 Functions which had prevtously been under the jurisdiction of the institutions of the 'kehilla', such as the collection of promissory notes and the liquidation of businesses because of bankruptcy, therefore were now transfered to government officials. 36 Internal Jewish court actions for example could now also be reviewed by the state authorities if any party so desired. 37 While the Western European states did not actually abolish the internal political organisation, in this way they began to weaken the community's hold on its members. In Russia however, the 'zeal' to enlighten the Jews led to the forcible recruitment of Jewish boys into the army, the partial abolition of the communal autonomy of the Jews and compulsory instruction in secular subjects. 38 Furthermore, the Russian government sought by decree to force the Jews to give up their traditional dress and appearance. 39

Internally, from within the Jewish communities themselves, the pressure was equally strong for the Jew to leave the ghetto and assimflate into the surrounding population. Caught in the spirit of the Enlightenment a handful of Jewish intellectuals had begun before the French Revolution to pressure for the emancipation of the Jews. However, after the revolution, with new economic opportunities and occupations from which the Jews had previously been barred suddenty opening up to Jewish entrepreneurs, the Jewish bourgeoisie now began 
asking "if the time had not come for all Jews to modernize, to productivise themselves, by moving into more usefut and dignifled livelihoods and wrestling themselves from the constricting lock-step of parochial Jewish education." 40 More and more volces thus began to be raised in favour of change. The traditional jewish community, it was argued, had to adapt to the changing historical social conditions and keep up with cultural and scientific progress.

- The decisive turning point however occurred "only when the individual members of the Jewish community transferred their soctal. goals to the context of the surrounding non-Jewish milieu." 41 In other words, when "individuals began to regard the non-Jewish society not only. as the framework for economic activity, but also as the source of social gratification." 42 previously, such a change in social ambitions would have automatically meant a 'crossing over' from the Jewish to the non-Jewish society. Without the necessity of converting, a new soctal elite thus emerged among the Jewish population. This new type, the 'maskil' (intellectual) added to his knowledge of the Torah a command of foreign languages, general erudition and an interest in what was happening in the non-Jewish world. 43 With the formation of this elite "new ideals pertaining to daily living, the organization and leadership of society, and the methods of education came to be formulated in a programmic manner." 44 This process is particularly exemplified by changes within the Jewish educational system. Not only was a 'gentile' curriculum introduced into many of the Jewish schools and colleges, but in many cases Jewish youth began attending public schools. 45 
The new ellte argued therefore that it was possible for a Jew to live in two worlds at the same time. He

arrayed himself in a short German coat, cut off his earlocks, shaved his beard, neglected his religious observances, spoke German or 'the language of the 1 and', and swore by the name of Moses Mendelssohn. 46

Mendelssohn, who had died just 6 years before Napoleon's official announcement of Jewish Emancipation, had been an early leader of the new 'rational' elite, and had committed much of his life to the cause of Jewish Emancipation. As many of the 'maskilim', Mendelssohn's
entire spiritual being and social activity were conditioned by the double connection--to his religious communtty and 'thus to traditional Jewish society on the one hand, and to groups of rationalists

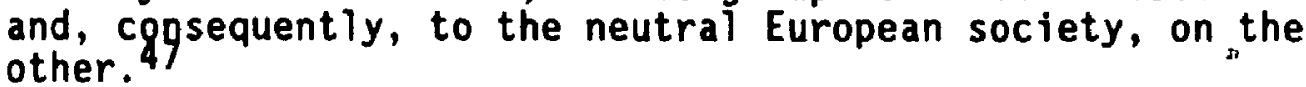

However, while Mendelssohn did manage on the whole to preserve his attachment to the life and the principles of his original religion, (although he did have four of his six children baptised), for the vast majority of Jews thas dualistic position was too difficult to maintain. ${ }^{48}$ Thus by the time these 'maskilim' reached their greatest strength and had laid "claim to the leadership of society as a whole ..." the majority had taken a far more radical stance towards Judaism. ${ }^{49}$ While Mendelssohn had still clearly recognised the activist element of Judaism and the importance of the Jewish. 'legislation' or commandments in order to preserve the Jewish ethnic group so that it may fulfill its priestly mission, later 'maskilim', in particular after Napoleon's ascent, increasingly saw Judaism as solely a faith or a belief. For this elite, in order to become enlightened citizens of the 
modern nation-states, traditional Jewish observance as well as the notion of a Jewish nation had to be rejected. It was thus that the slogan: 'Be a Jew at home and a man on the street' became the rallying cry for these new leaders. 50 They saw themselves no longer as Jews but "Germans, Frenchmen, Englishmen, etc., of the Mosaic persuasion'. .51 They thus separated what had previously been regarded as undentably bound together with the national and feliglous components of Judaism. One particular advocate of emancipation in Germany even went so far as to declare that "a Jew who preferred a non-existent state and nation (Israel) to Germany ought to be put under police protection, not because his views were dangerous but because he was obviously insane." 52 This is an especially interesting comment in light of the rise of zionism in the not-so-distant future.

A "crisis of the first magnitude" 53 therefore ensued as many Jews of that time struggled with the decision of whether to preserve the link with their Jewish origin or to choose the path of conversion. 54 The crisis began to develop as many Jews found they were unable to live divided between two societies; with one. foot in the Jewish community and the other in the new enightened or 'neutral' society. Literally thousands, having rejected traditional Judaism and caught in the spirit of the Enlightnment, finally chose to convert to Christianity. Emancipation for many therefore came merely to mean an intermediate stage or even a helping hand on the road to conversion. However this was not just a crisis of the individual Jew, it was a crisis of national identity for the Jewish people as a whole. By separating nationhood 
from religion, ethnic-based nationalism had threatened the very essence of Judatsm and Jewish identity. What did it mean to be Jewish in the new nation states?

The crisis seemed to explode with the onset of the shocking pogroms in Russia between 1881 and 1884. These were accompanied by the 'Temporary Rules', under which "Jews were forced out of the agricultural areas of the $\mathrm{Pal}$ e of Settlement; theyuere usubmitted to a strict 'numerus clausus' in the schools and universities; their trade was * hindered, so that many Jewish artisans found themselves financially ruined." 55 This was soon followed by attacks on German Jewish communities as well as the Dreyfus affair in Western Europe. Jewish emancipation seemed a total and abysmal fallure. Having wholeheartedly embraced the alms and philosophy of the Enlightenment, and thrown themselves heart and soul into the service of the state, the Jewish comatunities of Europe were shaken to their foundations by what they percefved as a betrayal by the new societies, the new states they had been asked to join. The possfibility of joining the Gentile world as equal partners seemed a distant naive dream. Yet the self-enclosed traditional world of the Jew and more importantly Jewish national identity had practically been destroyed.

Seen in a historical perspective therefore, a tension between the modern concepts of both religion and nationalism and the unity represented in Judalsm between religion and nationhood has existed since the baginning of our modern political era of nation-states. 56 with the end of the world which based national identity upon religious adherence, 
61

Judaism was to find itself in perpetual 'battle' between religion and nationalism. The crisis of identity for the European Jews of the nineteenth century marked the first round of such 'battles'; it was the first in an ongoing cycle of redefinition, so long as religion and - nationalism are regarded as dichotomous loyalties. It is essentially this same 'battle' that is reoccuring under different circumstances in Israel today. However, the emergence of Zionism in response to the crisis of identity of the Jews of the diaspora must first be examined. 
Endnoties

1 Raphael Patal, Ihe Jewtsh Mind (New York: Charles Scribner's Sons, 1977), 258.

2 Isidore Epste1n, Judaism (U.S.A.: Penguin Books, 1959), 287.

3 V.D. Segre, Israel: A Soctety in Iransition Great Britain: Oxford University Press, 1971), 14.

- 4 Encyclepaedia Britannica Ready Reference, 1985 ed., s.v.

"Enlightenment."

5 Encyclooaedia Britannica Ready Reference, 1985 ed., s.v.

"Enlightenment."

6 Epstein, Judaism, 287.

7 Raphael Mahler, A History of Modern Jewry: 1780-1815 (New York:

Schocken Books, 1971), xv.

8 Ibid.

19 Ibid

10 Ibid

11 Patal, The Jewish Mind, 258.

12 Ibid., 258,-259.

13 Jasob Raisin, The Haskalah Movement in Russia, $2 d$ ed. (U.S.A.: Greenwood Press Publishers, 1972), 43.

- 14 Patai, The Jewish Mind, 250.

15 Encyclopad la Britannice Micropaedia Ready Reference, 1985 ed., s.v. "Europe."

16 Jacob Katz, Iradition and Crisis (New York: Schocken Books, 1971), 
13.

17 Amos Elon, The Israelis: Founders and Sons (Israe 1: Adam

18 Segre, Dan V. Acrisis of Identity (U.S.A.: Oxford University Press, 1980), 51.

19 Ibid., 126.

20 Gwyn Rowley, "The Land of Israel: A Reconstructionist Approach," in Ihe Impact of Gush Emunim, ed. David Newman (Great Britain: Croom Helm Ltd., 1985), 127.

21 Segre, crisis of Identity, .128.

22 Leo Schwarz, ed., Great Ages and Ideas of the Jewish Peogle (New York: The Modern Library, 1956), 276.

23 Ibid ., 272.

24 Ibid., 272-273.

25 Elon, The Israelis, 45.

26 Jacob Katz, Iradition and Crisis (New York: Schocken Books, 1971), 7.

27 Elon, The Israelis, 45.

28 Patai, The Jewish Mind, 259.

29 Ibid.

30 Schwarz, Great Ages and Ideas, 317.

31 Patai, The Jewish Mind, 261.

32 Ibid.

33 Ibid., 262.

34 Segre, crisis of Identity, 25.

35 Katz, Iradition and Crisis, -248. 
36 Ibid.

37 Ibid.

38 Louis Wirth, : The Ghetto, 9th ed. (U,S.A.: University of Chicago Press, 1966), 100-101.

39 Ibid.

40 Howard Sachar, A History of Israel: From the Rise of Zionism to Our

- Time (New York: Alfred A. Knopf, 1982), 8.

41 Katz, Iradition and Crisis, 251

42 Ibid.

43 Ibid., 246.

44 Ibid?

45 Rowley, "Land of Israel," 130.

46 Wirth, The Ghetto, 100 :

47 Katz, Iradition and Crisis, 255.'

48 Patai, The Jewish Mind, 243.

49 Katz, Iradition and Crisis, 259.

50 Schwarz, Great Ages and Ideas, 381.

51 Epstein, Judaism, 291.

52 Segre, crisis of Identity, 24.

53 Epstein, Judaism, 290.

54 Katz, Iradition and Crists, 257.

55. Epstein, Judaism, 26.

.56 Segre, Crisis of Identity, 126. 


\section{Chapter Four}

\section{Religious Zionists. Anti-Zionists and Mon-Ziontsts:}

\section{Religious Reaction to the Secular Zlonist Mevement}

Chapter four shall examine the Jewish reaction to the crisis of identity it was experiencing in Europe, particularly that of the rise of Zionism. Most importanly, this chapter will look at the various religious reactions to the national liberation movement of the Jews. While religious Jews were distrustifil of nationalism, most soon realized the need to work with the Zionists to protect the religious identity of the people. Then, as today, it shall be shown, the struggle to create a new national identity for the Jewish people was to divide the population not merely along religious and secular lines, but between secular Zionists, religious Zionists, non-Zionists, anti-Zianists and various shades in between.

With the pogroms of Czarists Russia in the 1880s, a crisis of jdentity broke out amongst the Jewish population as never before. Confused and divided, without any form of overarching or united leadership (nor trained Teadership), there existed no clear path, no unified direction which the Jewish people as a whole ought to take. The very essence after all of who was a Jew, of what defined the Jewish people had been challenged and undermined with the Emancipation. The question of what the Jews should do was therefore 'open' to fierce and ied debate. What direction should the Jews in order to protect themselves as a people take? It was in Eastern Europe that the 'lead' 
was taken. Amongst those who sought change, sought relief from the 'Jewish problem', three avenues began to emerge as 'ways to bring about such a change and alleviate the sftuation of persecution. The first was to flee from the pogroms and in most cases emigrate to America; the second, within Eastern Europe, was revolutionary politics; and the third was a new national liberation movement, a direct product of the 'enlightened' philosophies of the time, called Zionism. It was this third movement which most directly and seriously affected the religious Jews. Speaking on behalf of all Jews, the Zionist organization presented an ethnic-nationalist definition of the Jewish people. The Jews, it argued, were a nation like all other nations, and as such deserved their own land, their own state. The tragic failure of the emancipation had made it perfectly clear that the Jems could no longer remain in 'foreign' lands and amongst 'foreign' peoples; the time had come for the Jews to emulate those liberation movements fighting for national rights throughout Europe. The criteria for nationhood in this modern state naturally would be based upon ethnic-national lines. Religious reaction to Zionism was however strong. Perceived as usurping the will or divine plan of God, many Orthodox refused to acknowledge the movement. Slowly but surely gaining momentum, the zionist movement. needed the adherence of the Orthodox to gain a greater sense of legitimacy amongst large sections of the Jewish community and to lend validity to their claims. Orthodox Jews in return also became concerned as to the challenge Zionism was presenting to the religion itself and the potential effect upon its followers. By providing for a Jew' to be a Jew without having to practise the religion per se, Zionism threatened 
the very religion. Zionism inherently articulated a fundamental tension between the two visions of national identity. In one nationalism is. traditionally steeped in religion while the other takes a view that separates Jewish nationalism from religion. ${ }^{1}$ Ethnic-nationallsm therefore proved unable to 'replace' traditional religion as a form of identity. The concept of nationhood is too integral to the Jewish religion. If Zionism was to represent all Jews and attempt to promote a sense of Jewish national identity, it was forced to employ those terms, those dreams, and those symbols that had held the Jews together for over two thousand years. Religious identity therefore was not to be forgotten nor somehaw 'superceded'. Orthodox Jewry and religion were from.Zionism's inception a vital element in its movement and history. .Hardly a monolithic block, the religious Jews were furthermore divided

I amongst themselves as to what form this new national identity should take. Then, as now, orthodox Jewry found itself divided into roughly three 'camps': Zionist; non-Zionist; and anti-Zionist. Distinguished by differences in their attitude to Zionism as weld as their varying. programmes; all three were then as now extremely active in attempting to shape and influence the direction the new nation-state would take.

The most popular 'avenue' of change was by far that of emigration to the United States. While according to Amos Elon only some 7,500 Jews left Europe for the United States between 1800 and 1870, after the pogroms of 1871 more than 60,000 Jews left Eastern Europe in thrat decade and 40,000 of them for the United States. ${ }^{2}$ By the end of the $1880 \mathrm{~s}, 200,000$ more had left for the States and in the $1890 \mathrm{~s}$ this number 
had increased to $300,000.3$ Finally between 1900 and 1914 a total of $1,500,000$ Jews left Russia for America. 4 In what can be called a mass exodus, a total of almost one third of Eastern European Jewry left in less than forty years.

The reasons for the choice of America were many. In addition to the fact that America was a 'developed' country in comparison to the sparsely-settled land of Palestine, America, with its illustrious revolution, seemed to embody all the ideals of the Enlightenment which had so bitterly let the Jews down in Europe. 5 A small but influential Jewish community already existed in the United States. The community enjoyed a high level of equality and freedom, and had taken an active part in the American Revolution and now saw its status being fully recognized by the new republic's constitution. 6 In addition, America was familiar; what enlightened Jew had not heard of Abraham Lincoln? Meanwhile for the small number of Orthodox Jews who chose to go to America, the United States demanded far less religious conformity than the most liberal of European states. 7

For those that chose to remain within Europe, political involvement appeared to be another potential source of change, in particular, radical or revolutionary involvement. As the Jews were the most urban of all ethaic groups in both Russia and Poland, political activity was a natural response; and while many ethnic groups were involved in the revolutionary struggle, the Jews surpassed all others in terms of their proportionate number of recruits. 8 In fact, Elon points out that between March 1903 and November 1904, 54\% of those sentenced 
for political offences in Russia were Jews. $9^{\circ}$ In addition, almost half of the delegates to the second Russian Social Democratic party congress of 1903 were Jewish. 10

These figures of the 1903 congress, however, did not include the number of delegates of the Jewish 'Bund', an abbreviation for "Arbeiterbund' (Society of Workers), established in 1897. A Jewish worker's party, the 'Bund' was affiliated with Lenin's Russian Soctal Democratic Party (although Lenin himself did not agree with the Bund's ethnocentrism) and in 1906 it alone comprised 30,000 of the dues-paying members of the Social Democratic party. 11 The only larger contigent were the Russians with 31,000 members, whlle the Poles comprised merely 26,000 ancinthe Letts $11,000.12$

Essentialiy the Bund viewed the problem of the Jews as one of class struggle and less as one of Jewish nationalism. While arguing that with the advent of socialism the situation of the Jews would be ameliorated, the Bund thought of the solution in terms of some form of Jewish national cultural and political autonomy within this socialist federation. In their struggle for social justice the Jews had to fight alongside the workers of the world against the oppressors of the working class. The ruling class oppressors were both non-Jewish and Jewish. To the Bund the proletariat of the Jewish nation in Eastern Europe was also being exploited by its own Jewish employers and 'clergy'.13 0perating a vigorous ( $\mathrm{clandestine)} \mathrm{trade} \mathrm{union} \mathrm{as} \mathrm{well} \mathrm{as} \mathrm{promoting} \mathrm{cultural}$ activities, the Bund received tremendous support from Jewish 
intellectuals but in particular from the working class. Elon for example points out that the

'Bund' caused more social unrest than non-Jewish trade unions.
Jewish workers in the Pale struck twice as often as workers in
Russia generally. They had one of the highest strike records in
Europe. Between 1900 and 1904 , of every thousand Jewish
workers, 58 struck; of every thousand Russian workers, 26.
Parallei figures for other European countries were; Germany, 11;
Belgium, 14; England, 15; Austria, 21; France, 30.14 . For much of the Jewish proletariat, the Bund's solution seemed the most practical; one could remain in one's own land and retain Yiddish as one's primary'language. With such impressive support, the Bund soon held a position of honour within the socialist movement as a whole. 15

The Bynd was to become a bitter rival of what was to later develop into the Zionist movement. Until Herzl and the establishment of the World Zionist Organization, groups and movements ideologica?ly and practically expressing the need for the Jews to return to the Land of Israel were individually springing up, often in a highly isolated manner, in hundreds of cities and towns across Eastern Europe. Like the Bund, these early clandestine Zionist clubs were generally socialist in nature, however the two were bitterly opposed to one another. While the Bund promoted Yiddish as the national tongue and fought for 'national' control of the schools, press and the arts within the future socialist state, the Zionists argued these hational rights could only be possible in a Jewish homel and. To the Bundists therefore, Zionism appeared as a bourgeois movement, merely deflecting the people from the universal class struggle that could only be fought where the oppression occurred. 16 While to the 2lonists, arguing that the Bund would never be 
granted the freedom and autonomy it was striving for, the Bundists were living in a fool's paradise.

Zionism, as a Jewish national liberation movement, however took a long time in developing before it reached any coherent and programmatic form. The forerunners of the official zionist movement were early on motivated by the inspiration of the nationalist independence movements affecting Europe and this they fused with the deeply held messianic belief of the Jewish people. The earllest and foremost exponents of this "self-redemption" form of 'Zionism' were interestingly enough Rabbi Yehuda Alkalai of Serbia (1798-1878) and Rabbi Tzevi Hirsch Kalischer of Posen, western Poland (1795-1874).17 Based upon the traditional messianic dream, Alkalai's book The Third Redemption (published 1843) was essentially a response to the Greek war of independence as well as the strivings of the Serbs, among whom he lived, to rid themselves of their Turkish rulers. 18 Alkalai felt that, the establishment of Jewish colonies in the Holy Land was a necessary prelude or preparation for the coming of the Messiah. Alkalat therefore argued that the Jews should purchase Palestine from the Turks, as Abraham had bought Machpelah from the Hittites in Biblical times. 19 Kalischer on the other hand was responding to Polish nationalism when he wrote Seeking zion in 1862.20 Supported by biblical texts and talmudic responsa, in which he was highly versed, Kalischer developed three principle theses in support of encouraging self-redemption. They were:

that the salvation of the Jews, as foretold by the Prophets, could take place through natural means, that is by self-help, and did not require the advent of the Messiah; that colonization 
of Palestine could be launched without delay; and that the revival of sacrifices in the Holy Land was permissible.2l

Redemption he argued would be ushered in by the "generating of support: among philanthropists and with the gaining of the consent of the nations to the gathering of the scattered Israel into the Holy Land".22 Kalisher's "practical messianism" therefore required the settlement of Palestine in order for the Day of Redemption to arrive. ${ }^{23}$ He thus urged his fellow Jews to

take to heart the examples of the Italians, Poles, and Hungarians ... All the other peoples have striven only for the sake of their own national honor; how much more should we exert ourselves, for our duty is to labor not only for the glgry of our ancestors but for the glory of God who chose Zion! 24

Although greater than that of Alkalai's, Kalisher's influence and support (despite his respect as a rabbinical scholar) remained relatively small; he was even denounced in Jerusalem. While secular Jews at this early time had not yet recognized the failure of emancipation and therefore rejected Zionism as an unnecessary alternative, orthodox Jewry saw it as a dangerous deviation from the true fatth.

A third "proto-Zionist" 25 was that of Moses Hess, who published his work Rome and Jerusalem in the same year as Kalisher did his, 1862. 26 A thoroughly assimilated Jew of his times, Hess as a socialist and a fellow student and friend of Karl Marx and Friedrich Engels was in othe very mainstream of Western European progressive thought. Influenced by the works of Italian nationalist Mazzini and the apparent success of modern Italian nationalism, Hess eventually came to the conclusion that 
assimilation was impossible and even dangerous for the Jews. 26 It was indispensible that they "shed their function as a historical anomaly" and establish their own state. 27 For it was the statelessness of the Jews, their existence as a national parasite in the lands of other people that was the cause of anti-semitism and persecution. Furthermore, this state had to be bullt along soctalist princlpies, for . a true

national renaissance was only possible through a return to 'productive' work on the soll within the framework of a jyst order, without social hierarchies, in cooperative units. 28

However Hess' message also was not to be heeded for over another twenty years.

Orthodox reaction to these early stirrings of Zionism was fairly low-keyed and revolved around primarily theological arguments. For the vast majority of religious Jews, return to the Holy Land by human effort was a sin on several accounts. The first was that humans were not to interfere with God's will, nor attempt to alter his Divine plan. Thus the return to Palestine was interpreted as a hastening of the 'end of days' and consequently a sin. The second reason, also prohibited by God at the time of Jewish extle from the Land of Israel, was that Jews were not to return to the Land of Israel by force. 29 Furthermore, the Jews saw religious meaning in their exile. Exile was seen as the punishment for sin, and only when the Jews as a people fulfilled all of God's commandments would they be returned to their own land. Some, later in history when Zionism was more developed as a movement, even regarded 
Zlonism as one of a series of trials plotted by Satan for the Jewish people. 30

Less important than the theological arguments at that time were the pragmatic ones. Opponents emphasized the near impossible logistic feats that would be needed to accomplish such large-scale migration. The proponents of settlement argued for the benefits of settlement in three different respects: firstly it was a means of alleviating the economic plight of the Jews; secondly immigration would fulfill God's commandment to settle the land; and thirdly, settlement would permit the fulfillment of commandments which could only be obeyed in the Holy Land. 31 Finally it was felt that settlement would provide the Jews with an opportunity to establish a religious community relatively. isolated and free from the secularizing influences of the Enlightenment in Europe. 32

However with the impact of Pinsker's writings and the establishment of the Hovevei Zion (Lovers of Zion) in 1882 the nature of these early discussions of return was to change, and consequently the nature and intensity of the reaction and the debate amongst the orthodox Jews as well. At the peak of the Jews' suffering in Russia, Leo Pinsker, an enlightened Jew of Odessa, was to write an essay entitled Aute-Emancipation that was to have a tremendous influence upon the future of the movement. Shocked by the pogroms of 1881, particularly by the participation of the 'cultured' and educated of Russian society, and influenced by the Bulgarian independence movement, Pinsker al so came to 
possession of a national homeland. In his essay, published 1882, Pinsker argued that

normal dealings between peoples were founded on mutual respect, not love; and [thus] it was unlikely the Jews ever could be accorded such respeçt, for they lacked its prerequisite of national equality. 33

The persistence of a stateless Jewish nation was the heart of what a Pinsker called 'Judaeophobia', a fear and hatred of the Jews. Neither enlightenment, assimilation, dispersion nor Jewish ultra-nationalism would therefore alleviate the cause of the problem; the only solution for the Jews according to Pinsker "was recognized nationhood on a 1 and, any 1and." 34 Auto-Emancipation however was above all else

a slashing attack on Jewish feebleness, timidity, and apologetics and on the Jews' deeply ingrained habit of seeking not only the sources of their pain outside Jewry but the cure to it as wel1.35

Partially due to its opportune timing and partially due to the directness and bluntness of message, Auto-Emancioation was to launch Pinsker almost overnight to a national figure and leader.

Auto-Emancipation was to prove the inspiration behind the first organized Zionist movement for Jewish settlement in the Holy Land, 'Lovers of Zion' (Hovevei Zion); the first cell of which was formed in Romania the same year Pinsker published his pamphlet. 36 One year later Pinsker became the president of the local odesisa cell and in 1884 Pinsker convened the Hibbat Zion's.'(Love of Zion) first national convention as the presiding chairman of the entire movement, a position: he was to maintain unti1 1889.37 At this point already two settlements 
had been established in Ottoman Palestine and by 1885 Hibbat Zion's membership had risen to a peak of 14,000--"mostly in loosely connected, underground and cultural circles which met in the homes of various writers and activists ...."m8

For the orthodox Jews therefore, Hibbat Zion had introduced a new element into the concept of Zionism. For the first time a group now existed that was actually engaging in settlement activity and that furthermore was not religious in orientation. Not only went the Zlonists usurping God's role by returning to Israel without the Messiah, but the religious Jews distrusted the concept of nationalism altogether. Nationalism had created a secular world, one that owed allegiance to human institutions and not to Divine authority. The debate thus shifted away from the thelogical and onto whether or not cooperation with secular Jews would be accepted or encouraged: Amongst those that

f. favoured settlement in the Hoiy Land in general were now those that opposed joint efforts with the non-religious. Those favouring cooperation with the Lovers of Zion emphasized the need for unity and cooperation amongst the Jews as a whole. In addition it was argued, all resources and manpower would have to be amassed if settlement was to be a success. More importantly however, they argued for the possible positive influence religious members could have on the non-religious in terms of returning to the ragion. ${ }^{39}$ Those opposing cooperation with the secularists on the other hand stressed the possible negative influence the secularists could have upon the religious members of the Hibbat Zion. Others objected based upon the commandment forbidding 
association with 'evil' people; while still others objected to the desecration. of the sanctity of the Holy Land in which violations of the commandments were considered particularly offensive. 40

As Hibbat Zion refused, to adopt any clear-cut position regarding religion however, the line between those opposing and supporting cooperation was not sharply drawn. Many supporters did eventually leave the Lovers due to what they perceived as a lack of religious adherence within the settlements themselves. Those that remained within the movement emphasized Hibbat Zion's practical stance and the fact that, while much of its leadership was secular, in generai its following was religious and therefore needed some form of guidance. The debate however was to shift once more with the creation of the Zlonism as an official movement and particularly when it became internationally recognized as the representative of the Jewish people.

The person why is officially known as the father of modern political Zionism is Theodor Herzl (1860-1904); born in Budapest and later worked in Vienna. 41 Accepting the fashionable view of the time that religious and racial prejudices would disappear in an enlightened society (and despite his early exposure to Jewish nationalism through his grandfather, a friend of Alkalat's), Herzl did not become significantly interested in Jewish nationalism until the Dreyfus trial of 1895 which was to propel him into the centre 'of the arena'. Oreyfus was falsely accused of giving military secrets to Germany. was eventually acquitted. Until he was freed, his trial proved to be an 1 ugly public demonstration of anti-semitism. Shocked by the intensity of 
the Katred for the Jews specialiy in a country where the Jews had so willingly embraced emancipation, Herzl published The Jewish state within one year. In it, Herzl argued that the Jewish question was one of a national problem; that it was not a religious nor a social one. Having tried, but not having been permitted to merge with other national communities, the only solution far the jews was a national exodus to the land of their own. However, unlike the approach of Hovevei Zion for example, Herzl rejected the idea of a gradual settiement and argued that the Jewish state could only be achieved if international recognition of the collective right of the Jews to a land of their. own were first obtained. To this end Herzl therefore proposed the establishment of two prgans: the 'Society of the Jews' to legally represent the idea; and the 'Jewish Company', a joint' stock company to financially support the movement. 42 Herz] was thus to provide the Zionist movement with his prestige as a political observer and journalist, his charisma, a working plan and formal organization as well as a place in the international political sphere. Within one year, August 1897 , the first Zionist Congress was held in Basle, Switzerland; to "lay the foundation stone of the house which [was] to shelter the Jewish nation." 43 Herz] managed to bring together all the disparate groups from all across Europe (many of which became aware of each other's existence for the first time) fostering some form of desire for national return to the land of Isfael.

There were 'reds', eager to participate in the clandestine,work of the socialist revolutionary parties; and 'blues', anxidas to stay out but nevertheless committed to an even more radical socialist policy. There was a bewildering mediey of in-between groups committed to various hair-splitting compromises; Marxist and non-Marxist socialists; anarchists and syndicalists; 
Yiddishists and Hebraists; unconditional supporters of Palestine as the future homeland. and territorialists who would accept Uganda or territory in Australia or America. There were religlous reformers and traditionalists. Some wished tô combine the national renaissance with a complete change of existing reforms, beginning with the family and ending with economic institutions; others-were ready to step at agrarian reform. There were liberal groups walting for a victory of the Russian constitutionalists and hoping that under them it would be possible to arrange an orderiy exodus of poorer Jews to their

- Palestinian hometand.44

Yet despite all this diversity the Congress went away having managed to agree both on a national anthem and a flag for the future state. Most imptatly however, the World Zionist Organization was officially created and the programme of action laid out in Ihe Jewish state was set into action.

Three general 'visions' of thd future Zionist state emerged from the Zionist leaders in these early yeats. The first was socialist Zionism, the second religious Zionism and the third a 'heterogeneous' stream, (what Isaac labels 'Zionism as a Refuge'), comprising those Zionist parties of the centre and right. It was Labour or Socialist Zionism which came beginning with the second aliyah (1905-1914) to dominate the movement however and with which the orthodox were most concerned. 45

Lour Zionism essentially argued that the plight of the Jews was due to two things: 'exploiting capital' and the "exclusive nationalism of the majority:"46 Due to the capitalist system, the Jews. had been cut off from those industries and jobs at the ceatre of production and thus were unable to fulfill the historic role within their potential. This in turn was further aggravated by their status as 
alien nationals which, after centuries of prejudice, prevented the dominant peoples from fighting side by side against the bourgoris oppressors with the Jews. Only in their own land therefore could the Jews join in the universal struggle for socialism. Only through labour, through ploneeringthe soll could the Jewish people achieve control of the means of production. Socialism thus became both a goal and a strategy for organising what was felt would be a characteristically Jewish society. The entire religious messianic dream of return for example was therefore re-interpreted by Labour Zionism along secular socialist lines. Rather than being politically liberated by the Messiah, national redemption would now occur through immigration to Palestine. The Messiah would no longer establish the new social order of perfect peace and justice, rather social redemption would occur through setting up an egalitarian society such as one found in the kibbutz. Finally, individual salvation would now come through working the soil of the Holy Land, and not through religious ethical preparation. 47

Religious reaction to this 'secular' or 'false' Messianism was. swift and strong. Prior to the opening of the First Zionist Congress, the orthodox rabbis of Germany were the first to formally object that

the efforts of the so-called Zionists to found a Jewish national state in Palestine contradict the Messianic promises of Judais as contained in the Holy Writ and in later religious sources. 48

More importantiy however was the fact that orthodox Jewry perceived Zionism as a threat, to Judaism itself. Zionism offered a national definition of the essence of Judaism and as such threatened to usurp the 
life. The religion itself appeared to be ynder attack. The Rabbt of Lubavitch for example complained:

$\therefore$ everyone who belongs to Israel must keep the Law and the Commandments, and that if he does not keep the Law and the Commandments he is not a Jew, ... But the zionists, have become ... skilled in evil, and have put nationalism in the place of Law and Commandments, and ... [say]... that not he is a Jew who keeps the Commandments, but he who is a Zionist .... is a Jew. 49

Similarly in 1898 in a letter to a colleague in Hungary the Rabbl of Brisk wrote:

With regard to the 2 ionists what-shall I say and what am I to speak? There is great dismay ... that these evil men who deny the Unique One of the world and His Holy. Torah have proclaimed with so much publicity that it is in their power to hasten redemption for the people of Israel and gather the dispersed from all ends of the earth. They have al so asserted their view that the whole difference and distinction between. Israel and the nations lies in natignalism, blood, and race, and that the faith and the religion are superfiuous. The chief of these ruffians $\ldots$ in our Holy Land has uttered terrible words; full of dental of the Most High ... For us ... it is a sure sign that' Dr. Herzl comes, not from the Lord but from 'the side of pollution', for we say, anyone who pleads in defense of Israel is exalted in the world by the Holy One, Blessed be He, while this evil man pleads in condemnation and multiplies accusation. 50

. Those orthodox Jews. who did participate in the World Zionist

Organization did so because they hoped to increase the role of religlous Jews in the Zionist movement and hopefully to. influence its ideology or at least -prevent it from adopting a stance antithetical to religious Judaism. Key to their parțicipation were Herzl's efforts to 1 imit the - Zionist movement to purely administrative, political and economic affairs, not cultural nor religious ones. In fact at the Second Zionist Congress, Herzl adopted the following resolution in order to prevent a. schism between the orthodox and the non-reigious zfonists: 
Congress, Herzl adopted the following resolution in order to prevent a schism between the orthodox and the non-religious Zionists:

Zionism aspires not only to a political and economic revival of the Jewish people, but to a spiritual revival as well, based on modern culture and its attainments. Zionism will not undertakf anything contrary to the commandments of the Jewish religion. 51

Under pressure from secular elements within the organization, this was soon to change. Three years later at the Fifth Zionist Congress, after bitter debate, a resolution, was passed declaring that the Congress "regards as a principal part of the Zionist program the ratsing of the cultural level by means of educating the Jewish people in the spirit of nationalism." 52 .From this point forward, the vast majority of Orthodox Jews perceived Zionism to be in conflict with traditional Judaism; it was an attempt to substitute "secular nationalism and concepts of territory, language and political sovereignity for God, Torah and religious community." 53 Most of the Orthodox thus promptly left the organization and those who did remaicelt it necessary to form a separate wing within the W.Z.O. devoted expressly to religious concerns.

In 1902 therefore, under the leadership of Rabbi Isaac Jacob Reines, the first political party within the World Zionist Organization was formed, the 'Merkaz Ruhani' (Spiritual Centre) or 'Mizrahi'.. The party was actually based upon a group of religious Zionists called the Spiritual Centre which, in order to distinguish itself from the secular members, had broken away from the Lovers of $Z$ ion and established its own - programme as early as 1893.54 Mizrahi therefore embraced Zionism from a 
view. 55 Religious law in other words was to reign supreme in the future state.

Following its establishment, Mizrahi issued a proclamation stating its ideology in relation to Zionism. In it Mizrahi argued that the impetus for Zionism rose not out of a physical threat nor out of anti-semitism, as these had always existed in the Diaspora. Rather, Zionism developed due to "the spiritual distress arising out of the attraction of modern culture that led to assimilation ..." 56 It was therefore necessary to support the return to Zion so that the Jewish people would become whole again and once more observe the laws of halakha.

In order to justify this position, Reines denied that Zionism had any cultural, religious elements. He insisted that it was only. concerned with practical efforts to improve the physical well being of the Jewish people by providing a secure haven. Thus Zionism posed neither a threat to traditional Judaism nor was it a substitute for the religious messianic concept. Furthermore, Reines emphasized the separation of one's material level of activity and one's spiritual level of activity, arguing that in the field of spirituality Mizrahi would pursue a programme in agreement with its orthodox beliefs (for example in 1909 Mizrahi created its own separate school system). 57 Following this reasoning therefore, Mizrahi was able to cooperate with the secular Zionists and the World Zionist Organization. Reines was in fact a very strong supporter of Herzl and, given how Zionism was merely a movement 
Zionists and the World Zionist Organization. Reines was in fact a very strong supporter of Herzl and, given how Zionism was merely a movement to provide refuge for the Jews, was'also in favour of the Uganda option at the W.Z.O..

Similar to the religious zionists, the religious non-Zionists also wanted to 'stamp the mark' of traditional Judaism on Zionism. However, unlike the religious Zionists, non-Zionists conditioned their cooperation with the secular Zionists that such demands were met. Most non-Zionists (as the label non-Zionist indicates) were against both the Zionist ideology and the World Zionist Organization; and most, but not a11, supported Agudath Isräel (Federation of Israel). They were however divided in terms of their attitudes towards practical efforts at settling the land and cooperating with the secularist 58 In general however, the majority of non-Zionists were opposed to both the ideology of the W.2.0. as well as its secular leadership, but not to resettlement of the Holy Land nor the establishment of a jewish state.

Agudath Israel was estabiished in 1912 in Eastern Europe by many of those. Jews who had '1eft the W.2.0. in 1901. Again the issue that, triggered its formation eleven years later was the passing of a resolution in W.Z.0. making cultural and educational work obligatory and calling for the establishment of Hebrew University. 59 Calling for the explicit recognition of the sovereignty of the laws of the Torah, Agudath Israel was later to completely withdraw from W.2.0. when the Organization was officialiy recognized by the British Mandate government as the representative of the Jews in Palestine. In addition it refused 
to participate in the political institutions of the Jewish settlements in Palestine. Initially it had been willing to cooperate with the other parties in Palestine but withdrew its participation over the 1ssue of women's suffrage. (An agreement was attempted in which all male members of Agudath would receive two votes; however Agudath refused to cooperate with those who would disobey traditional Judaism and give women the vote. ${ }^{60}$ ) Agudath was so opposed to Zionist ideology that it even contacted both Britain and the League of Nations in order to denounce Zionism and to insist that the Zionist Organization was at variance with the wishes of the majority of orthodox Jews. ${ }^{61}$ It justified its position on settlement (despite its belief that a return to the Holy Land could only be through the Messiah), as Mizrahi did, in terms of it easing the economic situation of the Jews in the Diaspora. There were however some elements within the movement (such as one of its founders, Isaac Brever) who did see it in national-réligious, even messianic terms.

Upon its establishment Agudath put. the direction of i.ts party in the hands of the Council of Torah Sages; a rabbinical body which would both govern the movement and serve as a legal authority. As Schiff states, by making a clerical authority paramount, Agudath thus distinguished itself "not only from non-religious Jewish organizations, and certainly from the WZ0, but from Mizrahi as we11." 62 ?

While Agudath was never to rejoin the W.Z.O., it did moderate. its position beginning in the 1930s and began to cooperate with the Zionist leadership. This was due to several reasons. On the one hand the Zionists had made impressive achievements in Palestine and Agudath 
came to realize that it would be unable to accomplish much without cooperation with the secularists. Furthermore with the rise of renewed anti-semitism in Europe after Harld War One Agudath saw immigration to Palestine as the only possible solution. The decision however was not an easy one, and unfortunately for many Eastern European Jews came too late.

Since the creation of the state of Israel, Agudath has taken an increasingly pragmatic approach. As it does not view Israel as the Jewish state and therefore with no significance to Judaism it is ideologically able to participate in its institutions. Furthermore, sing the majority of citizens are Jewish, Agudath sees its role as critical for the observant Jews.

The most vigorous opposition to Zionism, regardless of how one defined it, came from the anti-Zionists; 'in particular the Edat Haredit (Fearful Community) and Naturei Karta (Guardians of the City) who condemned Agudath Israel for not taking active opposition against Zionism and the state of Israel. According to the anti-Zionists, belief in Zionism was heretical. In fact Zionism was defined as a form of idolatry (the belief that phenomena can affect man independent of God), the most heinous of all crimes the Torah forbids. 63 Not only was it an act of rebellion' against God, but as such it would ultimately merely prolong the agony of exile. The tradegies in the diaspora, and later on Nazism, were seen to be a direct result of Zionist agitation. Zionist ideology it continues to be felt 
confound the Jewish nation. Consequently, it is the task of the faithful to do all in their power to separate themselves from this evil entergise, ilmit its influence, and pray for its destruction.64

In its most radical form today therefore Naturei Karta has not only supported Palestinian terrorism (in hopes it would hasten the end of Israel and Zionism), but has also contacted world-leaders to intervene with the Israeli government on the behalf of the movement. 65 . Once in fact, Naturei Karta lodged a formal complaint with the United Nations against Israel under Libyan sponsorship. 66

Naturei Karta argued therefore (and still does today) that "Torah nationalism" would only emerge with the advent of the Messtah and not any sooner. 67 Consequently any attempts at usurpation were to be severely punished and any form of cooperation with the Zionists was strictly forbidderf. Even behaviour which the tradition would normally affirm would lose its validity if associated with a secular zionist world view. 68

As did Agudath Israel, when the British recognized Zionism as the official Jewish representative in Palestine and established the 'City Council For The Jews Of Jerusalem' under Zionist leadership, many of the ultra-orthodox became upset by what they saw as secular domination. They thus formed their own separate ultra-orthodox community, 'Eidah Haredjt', officially called the 'City Council For The Ashkenazi 'Community'. This was establitshed solely as a political organ in order to represent its members wishes to both the mandatory government and world Jewry. ${ }^{69}$ First heard of in 1942, Naturef Karta 
in order to represent its members wishes to both the mandatory government and world Jewry. ${ }^{69}$ First heard of in 1942, Nature1 Karta gained control of the City Counctl of the Edah Haredite in 1945.70 Viewing itself as "all that stands between the Jews of Jerusalem and destruction", Naturei Karta is comprised of anti-Zionists from within Agudath Israel and Edah Haredite who were upset with Agudath Israel when it began taking a more compromising stance towards Zionism. ${ }^{71}$ It permanently broke from Agudath in 1949.72

According to the anti-Zionists therefore the members of Agudath and Mizrahi were traitors, collaborators who "sold their consciences in return for the financial support of the Zionist state." 73 Their claim to any form of authority was therefore besmirched. In addition to the theological arguments, however, the anti-zionists gave both tactical and 'spiritual' reasons to support their condemnation of the Zionists. Tactically Zionism was a dangerous idearbecause it strove to bring all the Jews of the world to one location, thus making them extremely vulnerable as a people. Spiritually, Zionism was perceived as threatening Jewish life itself by making the Jews a nation like all other nations; thus robbing Judaism of its very essence.

The line between the religious Zionists, non-Zionists and anti-Zionists however was never clearly drawn. Both Mizrahi and Agudath Israel formed their own labour parties in the 1920s, the 'Mizrachi Worker' (Hapo'el Hamizrachi) and 'Workers of Agudath' (Po'alei Aguda), respectively. These were establișhed to meet the special needs of the orthodox Jewish worker. However while in principle the 'Workers of 
Agudath' for example recognized the authority of the Counctl of Torah Sages, in practice it was more likely to disregard its rubing than its parent party, thus drawing it closer to Mizrahi.

From another perspective, Mizrahi and Agudath were both divided along 'messianic' and 'pragmatic' Iines. While Reines himself took a. pragmatic attitude towards Zionism, many followers within Mizraht saw the return as the beginning of Redemption. Rav Kook as well, the first Chief Rabbi in the Land of Israel, saw the hand of God in all the Zijonists did. He argued that the seculariats were not really secular at all because they were unknowingly fulfilling His divine plan. Breuer also, founder of the 'Workers of Agudath', viewed the Zlonist enterprize, the Balfour Declaration (1917), resettlement and the State of Israel all as manifestations of redemption. As mentioned above, Agudath and the 'Workers' as a whole were to take an increasingly pragmatic stancé.

Zionism was thus perceived in a variety of ways by the orthodox Jews. The two extreme reactions were those Jews that condemned 2 ionism and rejected all forms of cooperation with the seculartsts and those who embraced the Zionist movement as the beginning of Redemption. The centre of the spectrum held those who denied any ideological content to Zionism and were thus able to cooperate with the secular Zionists and those who regarded'ifonism as antagonistic but were willing to cooperate on a limited and practical basis. The various shades of opinion that lay in between were endless. The traditional religion was not simply going to be 'swept' aside by this new movement. Zionism threatened the 
Zionism began to gain momentum, and religion began to wane as the sole source of national identity for the Jewish people, some balance, some new form of national identity had to be reached between the two. Hence the different interpretations and stances the religion took towards Zionism. 


\section{Endnotes}

1 Zvi Yaron, "Religion in Israel," American Jewish Yearbook (1976), 47.

- 2 Amos Elon, The Israelis: Founders and Sons (Israel: Adam Press, 1981), 58.

3 Ibid.

. 4 Ibid.

5 V.D. Segre, Israel: A Society in Iransition (Great Britain: Oxford University Press, 1971), 28.

6 Ibid., 27.

7 Bernard Avishaj, The Iradegy of Zionism (New York: Farrar, Strauss Girous, 1985), 19.

8 Elon, The Israelis, 59.

9 Ibid.

10 Ibid.

11 Ibid.

12 Ibid.

13 Emile Marmorstein, Heaven at Bay: The Jewish Kulturkamof in the Holy Land (Great Britain: Oxford University Press, 1969) , 45.

14 Elon, The Israelis, 62.

15 Marmorstein, teaxen at Bay, 45.

16 S. Zaiman Abranov, Peroetual Dileitma (U.S.A.: Associated University Presses Inc., 1976), 59.

17 Norman Zucker, The Coming Crisis in Israel: Private Faith and 


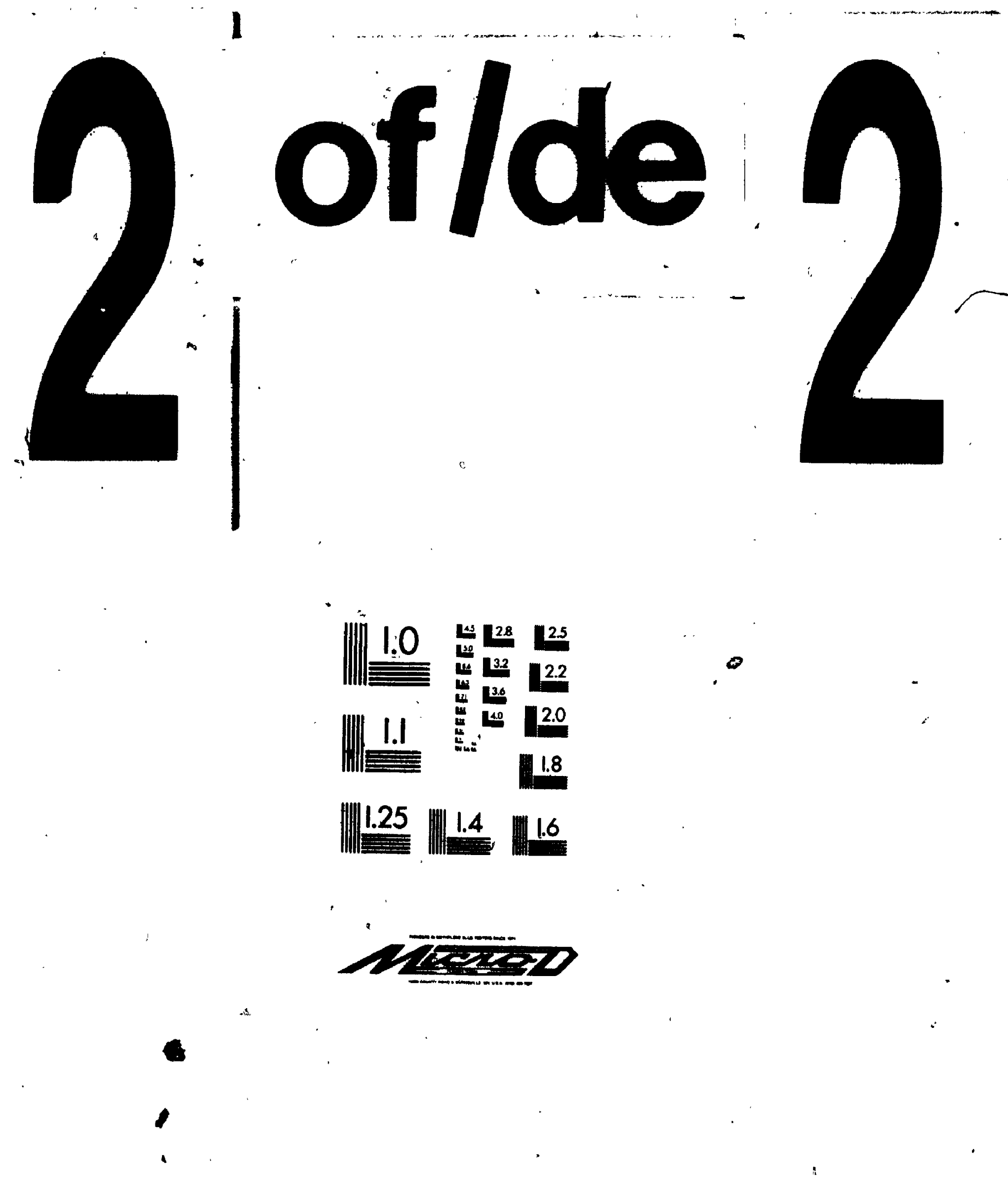


, Public Policy (U.S.A.: M.I.T. Press, 1973), 10.

18 Arthur Hertzberg, The Llonist Ided (Conneticut; Greenwood Press, 1959), 103.

19 Ibid., 104.

20 Elon, The 4 sraelis, 60.

21 Howard Sachar, A History of Israel: From the Rise of Zionism to Our Time (New York: Alfred A. Knopf, 1982), 7.

22 Ibid.

23 Ibid.

24 Hertzberg, Zionist Idea, 35:

25 Zucker, Coming Crisis, 11.

26 Sachar, History of Israel, 11.

27 Ibid.

28 Elon, The Israelis, 68.

29 Eliezer Don-Yehiya, "Jewish Orthodoxy, Zionism, and the State of Israe1," Jerusalem Quarterly 31 (Spring 1984), 11-12.

30 Rael Jean Isaac, Party and Politics in Israel: Three Visions of a Jewish State (New York: Longman Press, 1981), 18.

31 Don-Yehiya, "Jewish Orthodoxy," 12.

32 Ibid.

33 Sachar, History of [srael, 15.

34 Ibid.

35 David Vital, The Origins of Zionism (Great Britain: Oxford University Press, 1975), 128.

36 Elon, The Israelis, 70.

37 Vital, oriains, 143-144. 
38 Avishai, Iradeat of Zionism, 29.

39 Don-Yehiya, "Jewish Orthodoxy," 13.

40 Ibid.

41 Zucker, Coming Crisis, 17.

42 Sachar, History of Israel, 40.

43 Ibid., 45.

44 Elon, The Israelis, 73-74.

45 Sachar, History of Israel, 74.

46 Elon, The Israelis, 74.

47 " Lfly Wetssbrod, "Core Values and Revolutionary Change," in The Impact of Gush Enunim ed. David Newman (Great Britain: Croom Helm Ltd., . 1985), 72-73.

48 S. ZaLman Abramov, Perpetual Dilemma (U.S.A.: Associated University Presses Inc., 1976), 63.

- 49 Yigál Elam, "Gush Emurim: A False Messianism, " Jerusalem Quarterly i (Fal1 1976), 65:

50 Marmorstein, Heaven at Bay, 79-80.

51 Abramov, Perpetual Dilemma, 66.

52 Ibid., 67 .

53 Don-Yehiya, "Jewish Orthodoxy," 14-15.

54 Mark Tessler, "The Political right in Israel: Its Origins, Growth, and Prospects," Journal of Palestine Studies 15 (Winter 1986), 13.

- 55 Ibid, , 14.

56 Abramov, Peirpetual Dilema, 68.

57 Ibid., 73.

58 Don-Yehiya, "Jewish Orthodoxy," 15. 
59 Abramov, Perpetual Dilema, 73.

60 Isaac, Party and Politics, 39.

61 Ibid.

62 Gary Schiff, Iradition and Politics: The Religious Parties of Israel (Detroit: Wayne State University Press, 1977);70.

63 David L. J. Schnal1, Radical Dissent in Contemporary Israell Politics (U.S.A.: Praeger Publishers, 1979), 128.

64 Ibid., $130-131$.

65 Ibid., 135.

66 Ibid.

67 Ibid., 128.

$68^{\circ}$ Don-Yehiya, "Jewish Orthodoxy," 15.

69 Schiff, Iradition and Politics, 71.

70 Schnatl, Radical Dissent, 126.

71 Ibid., 125.

72 Ibid.

-73 Ibid., 129. 
Chapter Five

\section{$\sim$ \\ Continuity and Change: \\ The Decline of Socialist Zionism \\ and the Search for a New National Identity}

The decline of Labour Zionism as both a strategy and an ideology within Israeli-society will be traced in this chapter. Leaving a void in terms of national identity, the 1967 War it will be argued brought about the present-day identity crisis within modern Israel. Furthermore, this period of 'self-definition' that Israel is presently going through will be seen in the light of a continuous process; one that began with the development of nation states during the Enlightenment.

With the establTshment of the status quo in 1947 an arrangement was made between the secular and réligious forces in Israel which permitted the creation of the state and established acceptable guidelines for the new leaders to work under. However just as religion in the pre-state era was not to be relegated to some convenient role by the Zionists, the new Jewish state could not expect religion to simply. disappéar. Labour Zionism having fulfilled its goal of creating a state . for the lewish people was now to face the new challenge of developing that state. In meeting this challenge, Labour Zionism was to undergo dramatic changes to its character and ideological practices. White certain elements in socialist Zionism were to wane, others, were to take on new and greater meaning. As Israel's secular identity was to change, the religion was to prove once again that it. was not in fact obsolete as 
it rose to take part in the process of forging a new Israeli national identity. The trigger this time was the Six Day War of 1967.

Between 1948 and 1952 some 300,000 'Oriental' or 'Śephardic' Jews poured into Israel from Iraq, Egypt, Turkey, Iran, Yemen, Afganhistan, Caucasus and Cochin. ${ }^{1}$ Between 1955 and 1963 another 400,000 Sephardic immigrants were to flee to Israel from Algeria, Morocco and Tunisia. ${ }^{2}$ Within merely twelve years of its existence [srael had absorbed 1,200,000 immigrants; two-thirds of which'were 'Sephardim'. While the 120,000 or so from Iraq and approximately 10,000 from Egypt were generally educated and from a more cosmopolitan background, the vast majority of these new immigrants were impoverished, backward and uneducated; many of whom also came to Israel afflicted with tuberculosis, trachoma, ringworm, malaria, typhoid, dysentry, measles and pellagra. ${ }^{3}$ How was the new state to absorb all these new immigrants, feed them, clothe them, care for them, and educate them? They had to be taught Hebrew, taught skills, given employment; the. list seemed formidable. Was socialism in Israel capable of such an immediate challenge?

It was Ben-Gurion himself who first voiced the opinion that some new economic ideology would have to guide the new state. While socialist institutes had successfujly guided the pre-state period, Ben-Gurion came to doubt whether these enterprises, in particular the centrally controlled Histadrut corporations (the General Federation of - Hebrew Norkers) would be flexpble enough to allow the economy to expand sufficiently. Certainly a number of socialist institutions did grow 
under the first Mapai government: the 'kibbutzim' and cooperative agricultural settlements in general, the Sick Fund, as well as some of the Histadrut enterprises such as Koor (an industrial investment and management group), Solel Baneh (a construction company), and Hamashbir Hamerkazi (a chain of retail and wholesale distributors). Determined to meet the new challenges however, Ben/Gurion opened the economy to foreign-investors. In 1951 he perspnally launched the campaign to set7 Israel bonds and encouraged the establishment of private companies by foreign Jews. Even the kibbutzim Ben-Gurion insisted had to open their doors and employ outside, workers; in complete contradiction to the socialist ideology of the kibbutzim which did not allow wage labour. - By 1961 private enterprises were responsible for approximately three fifths of tatal output while the Histadrut and the state split the remaining two fifths. ${ }^{4}$ The Histadrut however now "ran businesses ... not ... proletarian associations. " 5 While Ben-Gurion still hoped the pioneering spirit of the settlers would be held up to the younger generation as a model, Israel in fact became increasingly capitalistic in nature. As earty as the end of the 1950 s "a profit-oriented entrepreneurial class $\because$ professing managerial norms" began to emerge in Israel. 6

The influx of the Sephardic Jews was to have a'more important consequence for Labour Zlonism's ideology however. These immigrants had very little understanding or interest in Eastern European Zionismpr a socialist political econowy. Many of them remained particularly aloof to Zionism as they saw it. as the source of anti-semitism in the 
countries from which they had been forced to fiee. Having lived in coúntries dominated by Islam, they themselves had

nurtured a rather Orthodox approach to Judaism. They had no feel for secular categories and expected messiaritc symbols to fire, the Jewish nation, whick was to them indistinguishable from the Jewish people .... [Furthermore], Islamic soctety had kept Sephadic fmmigrants strongly inclined towards sexual modesty and the inequality of women. They could not [consequentiy] accept the collectivism of Histadrut and kibbutz as a moral idea....7

The Sephardic immigrants' ideal therefore was that of freedom of private enterprise and owning one's own business. To the educated among them, manual labour, whether for wages or on a klbbutz, only "brought with it a certain shame, which was the more annoying if the manager spoke in socialist platitudes". 8 Well into the 1950 s consequentiy, the oriental Jews were to remain "objects of the zionist movement rather than subjects, simply destined tó fill demographic gaps ...." is

By the 1960s however even the European iminigrants to Israel had spurned the kibbutzim. Having been abandoned as the spearhead of the socialist Zionist ideology and economy, they began to resemble "an. extended family rather than a revolutionary cormunity" 10 or as ", Bevenisti stated, "retirement communities for like-minded people." 11 The small kibbutz elite was to remain frozen at a mere four percent of the population in Israej. 12 Within a relatively short period of time, economic egalitarianism or 'working the soll of Patestine', the keys to the social and individual salvation under Labaur Zionism, were no longer regarded as desirable by the Israeli population at large. 
Finally, by the 1960s, for the ftrst time since the 1920s, more young people were leaving Israel than coming to te.13 six million Jews remained in the United States and many chose to remain in Europe. The state had been created and there appeared to be no more masses that would be immigrating to Israel: Israeli leaders spoke the language of the old socialist Zionist, yet they were leading a capitalist economy. In his determination to build Israel, Ben-Gurion did not flinch from slaughtering any

sacred cows: the Palmach--the kibbutz-cormanded elite army unit--was disbanded and integrated into. the new state army; the socialist schools were disbanded and incorporated into the state schoor system .... Suddenly, it seêmed, one could be a pioneer and realize Zionst ideals out of a cozy office in Tel Aviv. ${ }^{14}$ *

New forms of pioneering had been legitimized. Whereas originally the call had peen for the 'best' to go to the kibbutz, the 'best' were now urged to go to the air force, the army, electronics and other careers. 15 The dominant parties stoll called themselves the leaders of the Zionist movement, but Israelis began, to ask themselves what exactly this meant. - Labour Zionism had become but empty language. Its rhetoric came to represent little more than state patriotism. Having rapidly lost its role as the strategy behind the building of the state, it no longer provided a source of identity for the vast bulk of the people. Y

Yet while the socialist elepent in Zionism waned, the religious element of Zionism was to strengthen and take on new meaning in the state's first twenty years. This occurred most prominently through the educational systein. In the period up to and shortly after Independence, separate school systems, had been maintained by most of the varjous. 
Zionist streams; the dominant socialist Zionists naturally were no. exception, The unification of the educational system under the bew state was to cause a radical transformation in Labour .Zionist education. Unlike the religious educational system, the socialist-zionist education in the course of being nationalized "lost [its] normative character and underwent astonishing dilution"; 16 it "simply disappeared". 17 The nature of the religious school system on the other hand was preserved (and perhaps even consolidated by the decline of Zionist education) by the religious camp's maintenance of its own school system. With increasing economic prosperity (in the form of state subsidies as well as donations from abroad) the National Religious Party, placed in control of religious education, was able to develop an all-inclusive educational system which encompassed not only the national rel rglous schools, but also yeshivot (Talmudic study centres), youth movements and associated instftutions. Around this educational system, "totalistic 1 ife Ratterns were created for an entire pubficf which reinforced its iffe not only at home and in the synagogue, but also ... in the neighbourhood kindergarten, in the ulpanah...or yeshivot..." 18 completely insulated - from the secular social and cultural environment, an intense socialization of religious values was able to take place. A *sociocultural environment or subculture was created from which newly synthesized and formulated nationalist-religlous values slowly but surely energed.

-.. - Thus soefalist Zionism, the ideology which had guided the early Israelis and created the state came to be so altered as to be. 
meaningless. With the erosion of Labour Zionism as the source of Jewish national identification in Israei, the 'Jewish question' was bound to explode again. Without the socialist identity, what did it mean to be Israeli, and more importantly, would 'Israeliness' require 'Jewishness'?

- Sooner or later the "different beliefs, conditions, and personalities ... had to $\mathrm{clash}$ among themselves over the very reason that brought them together" in the first place. 19 The only question was why a crisis did not erupt as one would have expected during the first two decades of the state's history. One reason was the astonishment and awe of the Jews at a dream come true; a state of their own after almost 3,000 years. A second reason was that of the continuing presence of Arab hostility which served to create a strong sense of unity among the Israelis. Finally, and perhaps most crucially, was Ben-Gurion himself who "imposed on all parties, much against their will, the historical decision of not deciding on any essential problems of the state: not on a constitution, not on the national borders, not on the ideological character of the State."20 Ben-Gurion's attitude therefore saved Israel from grave internal dissension. With his decision to maintain the status quo and to hinder the formulation of a constitution, Ben-Gurion actualiy averted or rather postponed what could be called a 'Kulturkampp' in Israej's first and most difficult years. Despite the vacuum created by the growing irrelevance of socialist Zionism and the changing sociocultural s. environment, Israelis and their political leaders were able to avoid confronting the question of the Jewi $>$ nature or identity of the state. 
The victory of the 1967 Six Day Har however was to trigger the inevitable identity 'crisis' in Israel. On the one hand it awakened what Elon termed $a$ "crisis of conscience". 21 The conquest and subsequent occupation of populous Arab areas compel Israel to look at itself not only in terms of its goals but the very nature of the zionist state. For the first time "young peopíe questioned the legitimacy of military service and the wisdom of allowing a soclety born of the craving to put an end to foreign oppression of the Jews to turn into a Jewish nation which ... was now forced to oppress a million conquered Arabs. "22 Painful analogies were dram-to the plight of the Jews in the not-so-distant past.

On the other hand, the 1967-War was to bring Israelis in touch with their 'Jewishness' as never before:- This is no more apparent than in the kibbutzim, not only the most secular of all Israelf institutions but the pillar of Labour Zionism, "where interviews"were conducted ameng 140 soldiers from a total of $27 \mathrm{kibbutzim}$ just after the war and - compiled in a book entitled soldfers' Ialk (Slach Lehamim). 23 While 'kibbutzniks' only comprise $4 \%$ of the population they did represent $25 \%$ of the war casualties. 24 What became apparent in these interviews was the sense of 're-unification' the soldiers felt with the Jewish people. For many soldiers the war brought with it an understanding, a feeling of 'we-ness' for the first time with the Jews who had lived for centuries in exile; in particular those who died in the Holocaust. As Herman notes, the 
... consclousness of the Holocaust was even more strongly present in 1967 than 1t was in 1948, conceivably because of the directness of the threat of destruction posed by the Arab state .... there are numerous references to the profound influence of the memory of the Holocaust as a background factor in their reaction to the threats of the enemy. 25

For many it was the first time they had seriously thought of themselves as Jews and belonging to a Jewtsh and not an Israeli nation, The most profound impact apon these secular soldiers, however, was the capture of the Western Wall. As one soldier observed:

In my unit we heard the news on a transistor, radio. When we - heard of the conquest of Jerusalem, there was not a single soldier who did not weep, including me. Then for the first time I felt, $80 t$ the 'Israeliness', but the Jewishness of the nation." 26

Said another soldier:

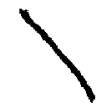

For me what symbolizes this war is the paratrooper who stood facing the Western. Wall, and could find no other, outlet for his emotion than tears; he was facing two thgusand years of exile, the whole history of the Jewish people. 27

The same feeling of 'Jewishness' was revealed agąin and again:

The paratrooper stood not only before the Western Wall--he stood before 2000 yegrs of exile, he stood before the history of the Jewish people. 28

Using the kibbutzin as just one albeft important indicator in Israeli society, the 1967 War triggered a profound period of self-questioning concerning the metming of their Jewishness and the meaning this held for Zionism and the state. Discussion groups and articles flourished concerning what was perceived to be the fallure of soctalist Zionism:

I believe they falled to create a substituite. They developed a $\therefore$ Torm 28 life indeed, but fatled to provide it with 
As Avishai stated in one of the many kibbutz publications concorning this self-examination following the war:

There is no escape from a return to religion.... labour culture failed.... We have reached a stage where we have to turn in the direction of Jewish knowledge ${ }_{30}$ towards the Jewtsh people and all that is associated therewith. ${ }^{30}$

In the aftermath of the S1X. Day War many Israel is became aware of the inseparability of the "ethnic and the 'religious, of the secular ang the sacred" of being Israeli. 31 The inherent Jewishness of being Israeli was dicovered. It was felt a new national identity was needed, a new fusion of the religious and the ethnic, to provide Israelis with a greater sense of meaning and purpose in life that secular labour Zlonism had been unable to give.

The Six Day War therefore can be seen as a watershed in Israell. culture and politics. It "reopened a whole set of issues related to the interpretation of modern Zionism and to the permanent borders of the State of Israel which remained uncesolved after the War of 1948." 32 This kind of self-questioning, this search for a new national identity and meaning can be seen on a larger scale, as Sprinzak notes, in the emergence for the first time of a new type of politics in Israel. 'The unshakable dominance of the Labour party in Israel was to be broken by the activation of small, vocal dissident political groups. For it was after the 1,967 War that suddenly groups such as mitzpen (the Israel1 Socialist Organization), Stah (New Israeli Left), Yesh (an Arab-Israeli student organization), Dov (Suppression of Trattors), Kahane's Jewish Defence League, the Black Panthers and Gush Emunim (Block of Faithfur) 
emerged. ${ }^{33}$ This type of 'extreme politics' was then to intensify after the Yom Kippur War. As defined by Sprinzak, extreme politics

is a type of political activity which is not directed and controlied by the institutionalized and established centres of authority in a given political system. In a democratic regime', extreme politics is that political activity which involves the direct action of extreme groups, and has to do with protests, demonstrations and systematic infringements of the prevailing law and order. Extreme politics does not concentrate therefore around the parliament and the cabinet, is not aimed at election day, and does not follow the accepted rules of the game played by blocs. 34 parties, major interest groups and central economic

Essentially these movements are not just attempts to challenge and undermine the Labour party, but to redefine what shape and form Zionism will take in the future. As shall be demonstrated, Gush Emunim epitomises exactly this attempt to change the face of Zionism. Today Israel still is going through this type of self-questioning as to what it means to be Israeli, what it means to be Jewish and what this means for the state of Israel politically.

For orthodox dewry in Israel the Six Day War was also a turning point. Politically, it marked the end of the National Religious Party's (the merger of Mizrahi and HaPoel HaMizrahi) unquestioning coalition with the dominant Labour Party and, more importantly, the entrance of religious political activity, into areas such as foreign policy and economic affairs. In the words of the former director-general of the Ministry of. Religious Affairs, Israel Lippel, on a religious level it "sparked a religious awakening and a growing sense of messianism." 35 Finally in terms of the question of national identity in Israel, it triggered the rise of a religious-nationalistic group called Gush Emunim 
(Block of Faithful) which proclaimed not a new but a return to a 'trua' definition of Zionism for Israel.

Politically Gush Emunim was the spearhead in the movement to settle the West Bank. Shortly after the war, the members of Gush Enunim initiated their plans to settle the West Bank. Within weoks a group of members returned to $\mathrm{Kfar}$ Etzion, a religious settlement taken by the Arabs in 1948, and settled there. Shortly afterwards, in the spring of 1968, after illegally squatting in the town hotel, Gush Emunim recelved permission to establish a yeshiva, which later grew into 250 housing units, in Kiryat Arba on the outskirts of Hebron. Gush Emunim thus originally focused its efforts on forcing the government to recognise settlements-that had been established in the West Bank. In almost all cases the government initially agreed to what was seemingly a modest demand, (such as the establishment of a yeshiva in Hebron), that was over time expanded into a permanent settlement. In this manner both Ma'aleh Adumin, east of Jerusalem, and Ofra, east of Ramallah, were established in 1975 after Gush pressured the government into agreeing to the establishment 'of a camp for workers from nearby industrial zones; and similarly a field school became the' settlement of Sebastla, near Nablus. After eight endeavours, after which the settlers were repeatedly and forcibly evacuated by the army, Gush Emunim also recefved the permission to allow the settlement of Kaddum to remain. In the summer of 1976, Gush Emunim shifted away from spontaneous settlement and established Amanah, a formal institution through which settlement activities in the West Bank are organized and sponsored. Today there 
are over 100 settlements in the Occupied Territories. Gush Emunim thius transformed the West Bank landscape into one dotted with numerous small Jewish settlements. Although the Gush are by no means the only group involved in the West Bank today, "there can be no doubt that they constituted, and remain, the major force behind such activities." 36

What gives Gush Emunim its relentless drive and confidence is its messianic-nationalistic belief that Israel today is witnessing the process of Redemption and that it is incumbent upon all Jews to do what he or she can do polftically to aid thts process. Gush Emunim thus exemplifies an attempt to forge a different form of national identity in Israel; a 'new' balance between secular and religious notions of nationhood which they argue is a return to original Zionism before it 'went wrong'. Essentially, the ideology of Gush Emunim is based upon the teachings of Rabbi Auraham Kook, the first head rabbi of Jaffa and then the Ashkenazi chief rabbi of Palestine. In contrast to most of the Orthodox of his time, nationalism or Zionism to Kook was "a divine principle, reinforcing the Covenant between God and the Jewish people." 37 Modern Zionism was in fact the instrument by which God was carrying of the divine purpose; the proof of which was the growth of the 'yishov' in Israel. : An understanding of Kook's view lies in his untque Kabbalistic Messiantc approach,

according to which much wore is hidden from sight than is seen: The external manifistations we encounter in our world represent only the bahest fraguent of cosintc existence, and God has his own ways of bringing about redenption even if those who play a Messianfc historic role--the secular Jews--are not fully aware of 1 t. 38 
The Jewish people Kook taught therefore are living in "an ora which has heralded the beginnings of the redemption process." 39

The teachings of Rabbi Kook however became influential only later when translated by his son into more concrete terms. After Kook's death, the Merkaz.HaRav Institute he headed fell into decline. It was not until the late 1950s, within the "slow but massive cultural process of educational transformation", that a new generation of students revitalized the old school. 40 This new generation "listened eagerly to the interpretations of the son of Rabbi Kook of the teachings of his father, and infused it with nationalistic meaning. "41

It was immediately after the Six Day War that Gush Emunim surfaced and exerted its 'New Zionism'. Three weeks before the 'liberation' of Judea and Samaria, the students of the Merkaz HaRav Talmudic Academy had witnessed Rabbi Kook Junior predict the Imminent end to: the partition of Eretz Israel. With the victory of the 1967 War,

the graduates of Merkaz HaRav were convinced that the genuine spirit of prophecy had come over their Rabbi on Independence Day. They, his faithful students, became holy emissaries. equipped with unshakable confidence in the rightness of their "mission and in' the Divine backing for their activity. At one stroke a flame was $1 \mathrm{tt}$ and the conditions were ripe for imparting ... the new political ideology of a greater "Eretz Israel. 42

For the members of Gush Emunim, (the leaders merged almost exclusively from Merkaz HaRav.Academy), , the occupation of the West Bank is a liberation of the territories of the Holy Land and is thus seen as a 'miracle; as "one of the' six strokes of the process of redemption.' 43 The coming of the Messiah has been shifted to the immediate present? 
The Gush Emunim leaders are convinced that they are "living in a most fateful period. If [they] prove to be the exclusive proprietors of Eretz Israel, of the parts [they] have already managed to 1 iberate, it w111 hasten redemption. " 44 Furthermore, since the return to the liberated solls is considered a sacred mission, no opposition to it may be tolerated. Those who demand Israel's withdrawal or submit to it are considered sinners and will be cursed by God. Settlement, according to Gush Emunim, is above all mortal laws. It is the duty of all Jews. to hold on to and expand the lands of Israel. The necessity of obtaining all of the territories is based on the belief that God promised the entire country to the sons of Israel. This 'divine title deed' therefore pre-empts all others. Political action such as settlements or protests (or for some even the attempted destruction of the Dome of the Rock, Islam's third holiest sight, in Jerusalem) is imperative in order to accelerate the process of Redemption. As such, political action can only be Judged by this standard; in other words what role it played in terms of Redemption. The ends justify the means. This rationale therefore Justifies vigilante activities in the West Bank against Palestinians. Gush Emunim's struggle for settlements in the West Bank therefore has not been one of settlements per se. To Gush Emunim, each settlement "Is a real link in the great chain that began at the first Zionist Congress in Basle at the end of the nineteenth century, continued with the Balfour declaration, the struggle agaimst the British White Paper, the establishment of the State of Israel and the Six Day War. "45 History is God's means of communicating with man. Through 
historical events such as the Holocaust and the Six Day Har, God expresses approval, disapproval and instructions. 16

Gush Emunim has therefore attempted to provide a new Israeli. identity ('new' in the sense of what had been hitherto dominant). It sees itself as a "movement of revival, whose task is to revitalize historic Zionism..." 47 Historic or 'classical' Zionism was not in order to normalize the Jewish condition by creating the state of Israe?, rather, according to Gush ideologue Rabbi Amital, "the proper a im of Zionism is to prepare the Jewish people to become the Chosen People. 148 The Jews, given their historic destihy, cannot be a 'normal' people. Israel cannot bè a normal nation. As such Israel is seen as an "expression of the eternal confrontation between Good and Evil and of Satan's desire to eradicate the Holy Land. "49 While the divine commandments of the Jewish people, according to Rabbi Shlomo Aviner, "transcend the human notions of national rights. "50 All those who try to oppose Israel's national rights to expand the Holy Land are representatives of the forces of Evil.

- Gush Emunim has thus attempted to revive one stream of religious-Zionism. It is an attempt to revitalize a declining Zionist mqvement and restore it to what Gush feels is its proper form and meaning. As such it exemplifies the type of questions and answers Israel has been undergoing since the Six Day War. The Gush does not represent one side of a 'battle' between the secular and the religious (even though Peace Now, the movement to withdraw from the Occupied 
Territories, is largely secular). Rather. it represents a one fusion or relationship between different definitions of nationalism.

Politically, the Orthodox in Israel were to undergo other changes as well after the 1967 War. However, as with the Gush, these too cannot be seen in the light of a 'showdown' with the secular Israelis.: They reflect rather once again the indivisibility of religious and ethnic notions of nationhood in Israelf identity and, as a result, religion's attempt to 'reforge' Israel's national identity with a changed Zionism and a changed Israel. Religious youth stemming from the same youth movement as many of the leaders of Gush Emunim, B'nei Akiva, (from which many went on to the Merkaz HaRav Talmudic Academy) were also to become influential in party politics after the 1967 War. The mid-sixties were to witness the rise of a youth faction, Tze'irim (known as the Young Guard) within the National Religious Party or 'Mafdal'. The challenge posed by this faction however was different from the many others within the party, for it "spught a new identity for the party. "51 Until 1967, both the N.R.P. (Nationai Religious Party) and Agudath had contained themselves to issues concerning policies and laws requiring obedience to orthodox Jewish law. In return for concessions in this area, they agreed to support a wide variety of both domestic and foreign policy issues proposed by Labour and opposed by Likud. As the Labour party had held sway since the creation of the state, this seemed to be the most logical and profitable path for the religious parties to follow. The Young Guard however proposed to transform the N.R.P. from one'concentrating on the special interests of the Orthodox to one 
applying religious principles to all matters governing the state, such as economic and foreign affairs. While the N.R.P. in general had been opposed to such a change as it would undermine the traditional arrangement between Mafdal and Labour, with the capture of the Holy Lands, the "1967 War provided the Tze'irim with censtderable impetus, for it opened up the opportunity of applying religious principles to foreign policy." 52 Arguing that Jewish law forbade the relinguishment of any part of the Holy Land, the Tze'irim were able to get a resolution passed at the N.R.P. convention that the party would polfticarity reject any moves to withdraw from the West Bank. Divisions within the N.R.P. prevented the issue from taking on as much importance as the more traditional issues such as Sabbath observance. However, the question of Judea and Samaria (as well as the Sina1) was eventually the cause of various groups to leave the N.R.P. and form their own religlous parties. These parties are more committed to a messianic ultra-nationalist ideology than is the N.R.P..

Due to divisions both within Agudath and in the N.R.P. between the Young Guard and in particular the previously dominant faction that was traditionally associated with Labour, Lamifneh, the Israeli political system has recently spawned a number of messianic-nationalist groups each striving for a new vision of Greater Israel. In 1979, in. response to Camp David and the agreement to return the Sinai, members of the N.R.P. joined a secular right-wing splinter group from the Lfkud and formed the Tehiya (Renaissance) Party. Highly militant, Tehiya messianic-expansionist programe includes 
a large part of Syria, to restore the Kingdom of David .... They want nothing less than the reinstatement of the Jewish people in the historical. Eretz Yisrael as it was at the peak of its power and its greatest territorial extent. 53

Tehiya thus favours settler underground movements carrying out terrorist activities in the West Bank. Two year's later, Morasha was established by Rabbi Haim Druckman, supporter of Gush Emunim and former. member of Knesset, and Hannah Porat of Tehiya. Morasha is dedicated to "the fusion of religiqus Orthodoxy and militant territorial maximalism" $;^{54}$ unlike Tehtya however, Morasha is strictly Orthodox. While Agudath as a whole-regards the Issue of the West Bank as irrelevant from a religious point of view (until the arrival of the Messiah the sanctity of the Holy Land is unaffected by the religious affiliation of its rulers), Po'alei Agudath Israel supports Morasha and helped it in the 1984 election to obtain two seats. Kach can be said to be the most 'extreme' of the 'messianics'. Rabbi Meir Kahane call's for the establishment of a Jewish theocracy in Israel and the expulsion of all Palestinians both within Israel proper and the Occupied Territories. These parties represent a small sample of the religious-messianic, secular-messianic, . democratic-socialist and spiritual parties which have sprung up in the wake of the 1967 War. The ones dealt with above represent those which formed due to specific concerns regarding the relationship between religion' and secular nationhood. Each represents a 'new' Zionism, a reformulation of the definition of nationhood in Israel.

This search for an identity, a different relationship with the secular ideologies and parties, one that weighs religion more heavily, is intensified by the nature of the Israelf political system itself. 
With a ' 1 is.t' system that encourages an abundance of small parties, the dominant parties in Israel have always had to. seek some form of arrangement or coalition with the smaller parties in order to ensure a majority and therefore the stability of the governing party. Traditionally, as stated above, Labour had an unquestionable arrangement with the N.R.P. With the decline of the Labour party after the war and the election of the Likud for the first time to power in 1977, the religious parties were to gain even more political influence. Begin, : known as "a fervent nationalist, one who was keenly aware of Jewish history and identified with religious values and ritual", depended heavily on all the religious parties (for the first time Agudath and not just Mafdal entered a coalition) in order to maintain a strong coalition. This put them in the unique position of being able to press. their accumulated demands in areas such as abortion, conversion, education and women's army conscription. 55 For the first time a religious Minister of Knesset was given a critical portfolio, the Ministry of Education. By 1981, in fact, 30 of the 83 ttems in the coalition agreement between Labour and its partners dealt with religlous issues. 56

Since the 1967 Har therefore Israel has undergone an intense period of self-questioning. Some 2,600 secular students enrolled themselves in 'ba'alei teshuva' yeshivot for the newly religious after the war and an unknown number entered various other religious inotitutions. 57 Within the national religious camp many moderates are
turning mora religious; they sense a "vagueness of purpose in the 
secular Zionist camp today ... that contrasts poorly with the structure and firm direction of the haredi world." 58 As the former head of the Bnei Akiva movement, Yochanan Ben-Ya'acov, explained:

The problem developed because 'the golden path' chosen by the religious Zionists came to be viewed, even by some of its leaders as a compromise, a function of circumstance, as they try to find their way on it between the perpyssiveness of secular society and the closed-in haredt world. 59

Gush Emunim as well as the increased political activity by the religious parties represent exactly such a search for a new identity for not just the religious parties but for Israel as a whole.

What is occurring in Israel. today therefore is not just a battle between the religious and secular forces. Triggered by the War of 1967 Israel has entered a painful period of self-examination. With socialist, Zlonist ideology unable to provide a national identity for the people of Israel it became apparent that a secular identity in general would be unable to provide the meaning and purpose that Israelis needed and soight. 'Who is a Jew' it was discovered could not jobe separated from "who is an I'sraeli". Israel has thus begun the-decisive process of " redefining its national identity and thus its future as a nation and a state. It is for this reason that the Israeli political system is as spltintered as never before. It is also due to this process of reformulating a national identity between one based on halakha and faith and one based on ethnicity and culture that visions for the future of Israel have reached such great extremes. With the failure of a secular nationalism, Israelits are faced with the same questions they confronted at the onset of the Zionist movement; in fact they ivere the same 
116

questions that triggered the creation of a Zionist movement. Then as now the 'dividing lines' do not lie between the secular and the religious, but rather between the various shades of Zionists, non-Zionists, religious-Zionists and anti-Zionists that each propose a different balance between religious and ethnic definitions of Israeli nationhood. Israeliness and Jewishness are intertwined and cannot be separated. Whether by religious or ethnic definitions, religious and secular Jews are bound to each other and together must decide the future of the nation. 
Endnotes

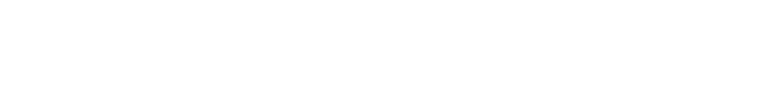

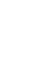

1 Bernard Avishai, Ihe Iragedy of Zionism (New York: Farrar Strauss Giroux, 1985), 207.

2 Ibid., 209.

3. Ibid., 208.

4 ibid., 215.

5 Ibid.

6 Auram Schweitzer, Israel The Changing National Agenda (Great Britain: Croom Helm Ltd., 1986), 22.

7 Avishai, Iragedy of Zionism, 207. .

8 Ibid.; 211 .

9 Reinhard Wiemer, "The Theories of Nationalism and of Zionism in the First Decade of the State of Israel, " Middle Eastern Studies 23 (April 1987), 184.

10 Avishai, Iragedy of Zlonism, 213.

11 Meron Benvenisti, Conflicts and Contradictions (New York: Villard Books, 1986), 63 .

12 Ibid.

13 Av̀ishat, Iradear of Zionism, 226.

14 Benvenisti, Conflicts ind Contradictions, 58.

15 Ibid.

16 Ehud Sprinzale, "The Icoberg Model of Political Extremism," in The Inouct of Gush Exunile, David Wewman (Great Britai: Croom Helm Ltd., 1985), 37. 
17 Eliezer Don-Yehiya and Charles Liẹbman, Civil Reltaton in Isriel (U.S.A.: University of California Press, 1983), 84.

18 Ibid.

19 Dan V. Segre, A.Crisis of Identity U.S.A.: Oxford University Press, 1980), 30.

20 Ibid.

21 Amos Elon, The Israelts; Founders and Sons (Israel: Adan Press, 1981), 262.

22 Segre, crisis of Identity, 32.

23 S. Zalman Abramov, Perpetual Dilemma (U.S.A.: Associated Unikersity presses Inc., 1976), 337.

24 Ibid., 338.

25 Simon N. Herman, Israèl is and lews. The Continulty of an Identity (New York: Random House, 1970), 211-212.

26 Abramov, Perpetual Dilemma, 338.

27 Ibid.

28 Herman, Ispaet is and Jews, 213.

29 Abramov, Perpetual Djlemma, 342.

30 Ibid., 341.

31 Ibid., 338.

32 Ehud Sprinzak, "Extreme Politics in Israel," Jerusalem Quarterly 5 (Fafl 1977), 37.

...33 Ibid:

34 Ibid., 33.

35 Jerusalem Post International Edition, 7 March 1987.

36 David Newman, "Introduction: Gush Emunim in Society and Space;" in. 
The Impact of Gush Emunim, ed. David Newman (Great Britain: Croom Helm L'td., 1985), 2.

37 Lilly Weissbrod, "Gush Emunim Ideology," Middle Eastern Studies 18 (July 1983), 267.

38 Sprinzak, "The Iceberg Model, " 29.

39 Ibid., 28.

40 Ibid., 37 .

41 Ibid.

42 Ibid., 37-38.

"43 Weissbrod, "Gush Emunim Ideology," 269.

44 Ibid.

45 Sprinzak, "The Iceberg Mode1," 29.

46 Ian Lustick, "Israel's Dangerous Fundamentalists," Foreign Policy 68 (Fall 1987), 127.

47 Sprinzak, "The Iceberg Mode1," 30.

48 Ofira Seliktar, "The New Zionism," Foreign Policy 51 (Summer 1983), 127.

49 Ibid.

50 Lustick, "Israel's Dangerous Fundamentalists," 123.

51 Rael Jean Isaac, Party and Politics in Israel: Three Visions of a Lewish State (New York: Longman Press, 1976), 79.

52 Ibid.

53 Michael Jansen, Dissonance in Zien (United Kingdom: Zed Books, 1987), 52.

54. Mark Tessler, "The Political Right in Israel: Its Origins, Growth, and Prospects," Journal of Palestine Studies 15 (Winter 1986), 35. 
55 Ira Sharkansky, "Religion and State in Begin's Israel," Jerusalem Quarterly 31 (Spring 1984), 31.

56. Ibid., 40.

57 Jerusalem Post International Edition, 7 March 1987.

58 Jerusalem Post International Edition, 19 December 1987.

59 Ibid. 
Chapter Six

\section{Conclusiens}

The questions Israel is presentiy facing are of profound. importance to both its domestic and foreign political future. In fact, to a degree they may even determine Israel's future. With $45 \%$ of the Israeli population rarely attending synagogue, the Orthodox demands for stricter sabbath enforcement, controls on abortions, transplant operations and autopsies, and attempts to introduce Jewish law into an increasing number of areas concerning Israeli public life, seem to threaten to split the country apart, especially when the Orthodox represent only $15 \%$ of Israelis at the utmost. 1 In the international sphere, the question of the annexation of Judea and Samaria, the home to approximately one million Palestinian people, will have serious ramifications for the entire Middle East. . Yet segments of the religious 'camp', guided by 'divine' authority and unconcerned about 'earthly' political considerations, are the driving force behind the settlement of the West Bank. What is happening in Israel today? How can one explain this 'sudden' militancy, this 'new' fanaticism? Why is it happening?

The tenstons Israel is now experiencing are not a surge of :fanaticism, nor the rise of religious 'fundamentalism'. They do not even strictly speaking represent. 'battle' between the religious on one hand and the secular on the other. They do represent however a 'battle' between different visions of Israel's national identity, of nationhood. And' it is a 'battle' not between the religious and the secular, but 
between Zionists, non-Zionists; anti-Zionists, those that are religious, those that are secular, those that are messianic and those that are pragmatic. Each has sought a different way of understanding nat lonhood in Israel, of bringing together two opposing definitions of nation. To argue that it is a question of a religious or a secular vision of the future would be to imply that secular Israelis see no place for Judaism in their national make-up nor state and that, more importantly, religious-minded israelis are not only anti-zionist but also unified in their attitude towards secular Zionism. This is simply not so. , Inherent in Judaism is a concept of a Jewish nation that bases 'membership' not only on birth, but on adherence to Jewish law. Challenging thrs since the nineteenth century is a secular notion of nationhood based upon ethnicity. For the vast bulk of today's Israelis however, one cannot be separated from the other. Zionist and Jewish notions of nationhood are inextricably bound together. Even the first Zionists, secularists by nature and ideology, could not escape shrouding their movement with religious, messianic terms in order to draw upon that bond, that feeling of 'we-ness' that had sustained the Jewish people over the centuries. The question is what particular batance shall guide Israel. Israel is undergoing a pertod of re-defining its "national identity. It is a process that involves a redefinition, a re-evaluation of the religious and secular components of nationalism. Furthermore, given the nature of Judaism, this is a tension, a 'battle' that is inherent to Zionism. It is the same self-questioning, albeit in A. a different context, that the Jews underwent as a result of the fallure of Jewish Emancipation; it is the same attempt to forge a new national 
identity as the one that produced Ziontsm in the first place. It is also the type of redefining, restructuring that Israel will most likely have to continue to undergo throughout its history.

$\infty$

In a well documented survey conducted in Israel on Jewish and Israeli identity amongst students and their parents, it was found that the large majority of Israelis perceive not only an overlap between Israeli and Jewish subidentities, but consonance or compatibility between the two. 2 "'Feeling more Israeli' is seen as implying 'feeling more Jewish,' and vice 'versa." 3 The two are inseparable. Zionism did not replace the Jewish concept of nationhood, it built upon it. Zionism is dependent upon and draws strength, identity and loyalty from its Jewish roots. Due to the very nature of Judaism, nationalism in Israel ean never be purely secular and strictly ethnically based as envisioned by the nationalist movements of Europe and the West. Zionism can therefore be perceived of as a pyramid with Zionism at the pinnacle and Judaism at the base. However if until recently Zionism could be envisioned as a pyramid, the struggle today is over a change in the geometric shape.

It is precisely this 'geometric shape' that has divided Israel. Israelis are divided as to what weight each component of nationhood will have in Israel. "It is not therefore simply a debate between the religious and the secular in which Israel will revert to a theocracy or implement a purely secular value system. Israelis are divided in their attitudes to Zlonism and this cuts across the religious 'camp' as well. To be more precise, Israelis are divided over their visions of what 
Zionism is or should be. This is the same search for an identity that occurred when Zionism was first created. While Ben-Gurion reached a balance between the two components that was able to guide Israel throughout much of its history, it is this balance that is now being restructured. And-it-will probably be 'renegotfated' again and again.

In the nineteenth century, Jewish communities" in Europe were torn apart by the spread of the ideals of the Enlightenment and the consequent rise of nation-states. In a world no longer determined by religious identity, the Jews were forced to ask themselves what it meant to be Jewish and most importantly how they could reconcile Jewish identity with the new secular ethnic national identity. These were essentially the same questions as the ones being asked today. Then, as now, the Jewish people were trying to estaplish a relationship between. two opposing concepts of nationhood. This tension between differing concepts of a nation and ultimately of the source of authority and 'ideology' is inherent to Zionism. In one, nationality is determined by descent (or conversion), authority rests in the Torah and therefore the rabbinate and 'ideology' is a belief in Jewish ethical values. In the other, a nation is ethnically determined, authority rests in secular 'man-made' instibutions and 'ideology' is a matter of political ideals. It was out of the ensuing identity crisis produced by this tension, the search for a new understanding of nationhood that Zionism arose; a Jewish national liberation movement attempting to emulate the European national movements of its time. 
Israel's present search for a new national identity, or rather a restructuring of the $01 d$, was triggered by the 1967 War. It was the war that made the changes which had been occuring within Labour Zionism blatantly apparant and forced Israelis into the present period of redefining exactly who they are. The war brought with it not only Jewry's reunification with the Western Wall, but the conquest and occupation of the West Bank, the biblical lands of Judea and Samaria. It was thus to spark a feeling of messianiam and an increased sense of religiosity amongst the Israelf people, in particular religious-minded Israelis. Combined with a crisis of conscience segments of the Israeli population were/are experiencing over the occupation of another people, Israel plunged into its present period of redefining the role of religion in its national identity. While Labour Zionism had been . undergoing its own transformation prior to 1967, the importance of the war in triggering this search for a new national identity cannot be underestimated.

$\dot{A}$ the time of the creation of the state, Labour Zionism was the dominant Zionist strearr. Under the guidance of Ben-Gurion, an accommodation was reached, the 'status quo', that was able to satisfy all the different elements, the differing visions of the future of the 'nation-state'. Labour Zionism was thus in firm control of the newly created state, it had delegitimized all other Zionist streams, in particular the Revisionists, and had established a solid alliance with the religious parties. After the 1967 Har, Labour's hegemony collapsed. The present-day 'Revisionists' are not only a legitimate political force 
in Israel but have been vićtorious at the polls. Extra-parliamentary political movements and a host of new smaller parties have been assailing the establishment in the challenge to create a ney nationalism. Most importantly, Labour's alliance with the National Religious Party has been broken. With the two major Israeli political parties, Labour and Likud, dependent upon' a coalition with the religious parties, the religious parties wield considerable power in Israel's political sphere. The War of 1967 was therefore crucial in shattering not only Israel's vision of itself as a nation but the previous dominant political arrangement (which in turn reinforced the former).

It is thus that today Israel is being pressured by conflicting views on the relationship between religious and secular notions of national identity. As in the nineteenth century, cleavages within Israelf society are determined by one's attitude toward secular zionism and what role religion should play in it. Religion and nationalism it appears cannot be separated.

Zionism therefore cannot be said to have 'normalized' the Jewish condition. The question 'who is a Jew' still cannot be answered nor for that matter 'who is an Israelf'. The question that must be asked therefore is if Israel ever can be a 'normal' nation-state as defined in the West. 'Normalization' of the Jewish question meant the creation of a state for the Jews, but more importantly this meant that the Jews would be a nation as all others; one based on ethnicity and 'earthly' and not 'heavenly' criteria. With' $15 \%$ of its citizens either Musilm or Christian Palestinians professing their own nationalism, Israel is at 
best a bi-national state. ${ }^{4}$ Furthermore with Jews having immigrated to Israel from all over the world, Jewish Israelis are also ethnically divided. In addition, only one third of world Jewry lives in Israel. 5 Most importantly, despite at least two generations that have been born and raised in Israel, Israeli identity has not replaced Jewish identity. 'Jewish' continues to be stated under' 'nationaity' in an Israeli' passport. The Israeli flag itself with the Star of.David symbolises the tension between a nation based upon Judaism and one based upon secular criteria. Based upon present Western definitions of nation and nationstate, Israel is not a nation-state and perhaps never will be. Israel represents therefore a new understanding of both nationalism and nation-state.

Yet given the nature of Judaism and the 'conflict' that has been inherent in the concept of nationhood since the inception of Zionism, why have the present day tensions within Israel come as a surprise? Why have the activities of the 'fundamentalists' and 'militants' been seen as new, as some sort of sudden resurgence? Why according to Western theories of nationalism is the recent role religion is playing in politics seen as aberrant and abnormal? Why didn't religion stay' in its place'?

Based upon the Western European example, nationalism has been viewed as something that supercedes and replaces religion as a form of identity. Furthermore, based upon a trend that Europe and the United States appeared to be experiencing in the mid-twentieth century, religion, it was predicted, as an active force would eventually leave 
public life altogether. Quite simply, Western theorles have applied the experience of one religion to all others, the experience of one continent to all others, and the experience of one time period to all others. The power of nationalism and this dream of a nation-state 'as all others' however is what guided the early zionists. It continues today to mold the ideas of many of those in Israel. It is however a vision that attempts perhaps to do the improbable, if not impossible. Just as the 'ideologues' of the Enlightenment felt they could dispose of or replace religion with a supposedly more rational, neutral basis for society, so too did Zionism. However early Zionists found that they were forced to contend with religion just as the state in Israel must presently do so today. Religion will not just disappear. Religion as an identity is rooted too deeply within a nation. Religion can and does move people. Religion can and does divide people. It remains a great ènough source of identịty to cleave peoples between an 'us' and a 'them'. This type of cleavage can be seen both within .the seculars and the religious-minded. The role of religion must be re-evaluated in thearies of nationalism. Without such a re-evaluation, events such as the rise of the Ayatollah and the present tensions within Israel will continue not only to be unpredictable but unintelligible. Yet these very events can have international repercussions. Furthermore, religion cannot be seen as something static and unchanging. Religion and change in religion must be viewed as something normal and continuous. 6 As such, religion's relationship with nationalism can be expected to also change. 


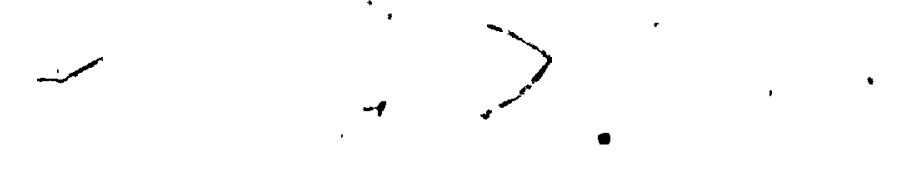

The case study of Israel has demonstrated that theorists must look at what religion is saying. Religions are a form of value system and have not only a way of 11 fe but an ideal and an identity they impart to their followers. This value system touches humankind's private and public life. And it wilj not simply step aside when it contacts other value systems. Furthermore, religions are different. They impart different values, different ways of understanding the world. They must be analysed in terms of what they each individually say. The Christian concept of religion is very different from that of Judaism's. The logif and expertence of one cannot be applied to the other.

)

We must therefore attempt to delineate the world from the standpoint of the believer. Not only must the we try to understand the structure of the religion, what it is saying, but how this worldview, this identity is understood by the believer. What impact, depth of feeling does this have on the believer. To do this however, as Merkl $\checkmark$ and Smart point out, we must be aware of our own structural biases, our own "cultural and conceptual apparatus" (such as the separation of Church and State) in order not to apply it to another worldview. 7 There must be a greater understanding of a nation's history and especially its particular culture. There must therefore be an attempt to understand the world from 'down-up'; how the world is being understood at the * 'bottom' and how this effects the politics at the 'top'.

This type of Western bias is also reflected in the terminology that is omployed in describing religious activism; terminology that is consequently inaccurate in its applicability to Israe]. The present. 
terminology is often insufficlent, constricting when trying to understand today's events. What is needed is a new terminology. Even the term 'religion' itself carries with it a concept of falth that is predominantly Christian. Judaism is more than just a faith, it is also a set of laws, the halakha, and it includes a concept of peoplehood. It can also'be thought of in the image of a triangle with Israel, God and Torah (peoplehood, belief, authority) in each of the corners. While the type of triangle may change, all three components are integral to' the religion and it will always remain a triad. 8 The word 'religion' thus too narrowlyidefines only the 'pervasiveness' of Judaism in dally life, but the worldview of the belfever. Shepard, for example, when dealing with the all encompassing nature of $p$ lam, suggests the use of the term 'Islamic totalism' rather than 'reTigion'.9 A simtlar term could perhaps better reflect the all encompassing domain of Judaism as well. Also the term 'secularist' must be more carefully defined. Secularists are not necessarfly irreligious as is most often tmplled. A secularist does seek a separation of church and state, but this does not imply that religion does not play a role in a secularist's national identity. The secularists therefore can also not be 'lumped' together but must be distinguished in terms of their attitude towards their national identity. Terms such as 'radical' secularists or a 'moderate' secularist however should be avoided; as it must be remembered that a 'radical' in one culture may be considered a 'moderate' in another. Perhaps the term 'pure' secularist, to denote a person denouncing religion in both polities and national identity or cultural heritage could be employed. When reviewing the terms applied to the 
religlous-minded, the inaccuracy is even more pronounced. Words such as 'fundamentalist' and even 'ultra-Orthodox' imply a radical religious extremist who wants to turn the flock back in time. The religlous-minded differ on what role religion will have in Israel's 1 pational identity, in practice this also implies what and how religious practices will be enacted. It is not however a question of accepting or rejecting progress. The orthodox Jews do not have any problem accepting modern technology and goods. They drive cars, use banking machines and even use home computers. Progress is not part of the debate; religious commandments are. The term 'fundamentalist' itself is a Christian term - originally used to describe those Protestants that "set themselves off from 'main 1ine' Protedtant ism through their belief in biblical inerracy and their literalist interpretation of the Bible. "10 The Orthodox are not extremists or radicals (as another favourite label describes them), they are not trying to go to the 'roots' of Judaism and implement a strictly defined archaic version. Even the term 'ultra-Orthodox' implies someone who is going beyond all bounds, unreasonably so. At times it even appears in the literature as if the 'ultra-Orthodox' are the ones that throw stones while those that don't are merely the Orthodox! What they are doing however is attempting to implement Judaism in an authentic way. 11 Rather than employing 'radical' or 'extreme' or 'ultra' perhaps a more applicable term would be that of 'purist'. Again, a differentiation must be drawn between the religious-minded in terms of their attitude towards secular national identity and institutions. The cholce of terms sets the tone of a 'debate'; furthermore, it not only organizes the understanding of a 
problem but sets definite limits to both this understanding and what fan " be done. 12 with a reformulation of the terminology perhaps at lieast discussions and theories regarding religion and national identity in Israel can be made more accurate and reflective of the true situation. :

What is occurring in Israel today wilt have profound implications for its future. It cannot be viewed as merely a cultural development nor as occurring within a vacuum. Both internationally and domestically the political ramifications can be expected to be far-reaching. Internally the present debate will determine not only the political direction Israel will take but its culture, its lifestyle. Externally the consequences may be even more profound. For this involves the entire question of the future of the West Bank, Judea and Samaria, and ultimately the fate of the Palestinian people living there. Gush Emunim for example is one segment of Israeli socfety which argues for the formal annexation of the Occupied Territories; ${ }^{13}$ for when led by a divine mission all moral considerations regarding the occupation of another people become insignificant. With the addition of over a million Arabs within Israel's borders however, the question must be asked as to what place the non-Jew will have in Jewish redemption. Furthermore, what will this large percentage of non-Jewish citizenry in Israel mean for Zionism and consequently democracy? In a Jewish state, can a non-Jew become prime minister? By deciding the definition of Israel's national identity now, Israel may be deciding not only the fate of the Palestinians but the fate of democracy in Israel. Kach for example argues that democracy and Zionisa are incompatible and proposes 
the expulsion of all Palestinians. The vast number of Israelis however are trying to find a compromise in between.

The intensification of Islamic movements in the West Bank, to a degree in reaction to Gush Emunim's 'Holy War' attitude, also must be considered. Guided by divine right on the same sacred soil according to each of the religions, there will be ro room for compromise of any form in the Middle East. There would no longer be any ratiohal actors nor 'rules to the game' as we know them in the Western world today.

The new Israeli consepsus will also have repercussions on Israel's traditional relationship with the western world, particularly the United States. Central to the U.S.'s relationship with Israel are the democratic, libertarian and universalistic values the two countries have shared. 14 Should Israel neglect these values with its new national identity it could possibly strain or even jeopardize its supportive relationship with the U.S.. Given Israel's political and geographic situation in the Middie East, such a risk is perhaps one Israel may not be able to afford to take.

Triggered by the 1967 War, Israel is presently struggling to define its national identity; a national identity that will determine its entire political future. It is the same crisis of identity that eventually gave birth to the Zionist movement in the nineteenth century. Then as now, the possibilities seem endless as different accommodations between Judaism's religious definition of nation and Zionism's ethnic one are encouraged by factions throughout Israel. Whatever new 
134

definition is reached however it will be one that cannot exclude either component --the ethnic or the religious --for the two have become and remain inseparable. As the case study of Israel demonstrates; religious activism is not only normal, it is here to stay. 


\section{Endnotes}

'1 Eric Stiver, "The 'War of the Jews', "Maclean's, 18 January 1988, 19.

2 Simon N. Herman, Israel ts and Jews: The Continuity of an Identity, (New York: Random House, 1970), 45.

3 Ibid.

4 Joseph.Agassi, "Will Israel Ever Become a Nation," in Nationalism and Modernity: A Mediterranean Perspective, ed. Joseph Alpher (New York: Praeger Publishers, 1986), 60.

5 Hugh Seton-Watson, "State, Nation, and Religion: Some General Reflections," in National ism and Modernity: A Mediterranean Perspective, ed. Joseph Alpher (New York: Praeger Publishers, 1986), 28.

6 Danial Levine, "Religion and Politics in Comparative and Historical Perspective," domparative Politics 19 (October 1986), 96.

7 Ninian Smart, "Conclusions," in Religion and Politics in the Medern Vorld, ed. Peter H. Merkl and Ninian Smart (4 S.A.: New York University Press, 1983), 269.

8 Raphael Loewe, "Judaism's Eternal Triangle," Religious Studies 23 (1987), 309.

9 William E. Shepard,. "Islam and Ideology: Towards a Typology," International Journal of Middle East Studies, 19 (August 1987), 308.

10 Levine, "Religion and Politics," 115. 
136

$1 \hat{1}^{n}$ Shepard, "I slam and Ideology," 314.

12 B.R.J. Walker, "Culture, Ideological and World Order...," in the Discourse of World Order, ed. Mark Blasius (Boulder: Westriew Press, 1984), 245.

13 As this paper is concerned with the role of religion in nationalism, those movements and parties of the secular right in Israel also supporting the annexation of the West Bank have not been dealt with:

14 Lustick, Ian, "Israel's Dangerous Fundamentalists," Foreign Policy 68 (Fall 1987): 139. 


\section{Bibliography}

Abbott, G. F. Israel in Europe. Great Britånn: Curzon Press

Ltd./Humanities Press Inc., 1972.

Abramov, S. Zalman. Perpetual Dilemma. U.S.A.: Associated University

Presses Inc., 1976.

Akzin, Benjamin. State and Nation. London: Hutchinson and Co. Ltd., 1964.

Almond, Gabriel and Verba, Sydney. Civic Culture. U.S.A.: Little, Brown and Company, 1965.

Alpher, Joseph, ed. National ism and Modernity: A Męditerranean

Perspective. New York: Praeger Publishers, 1986.

Aoderson, Benedict. Imagined Communities. London: Verso Publishers, 1983 .

Arian, Alan: The Choosing People. U.S.A.: The Press of Cape Western, 673.

Armstrong, J.A. Nations Before Nationalism. Chapel Hill: University of Nơrth Carolina Pressi 1982.

Aronoff, Myron J., ed. Political Anthropology Volume 2: Culture and Political Change. U.S.A.: Transaction Books; 1983.

Aronoff, Myron J., ed. Political Anthropology Volume 3: Religion and Polltics. U.S.A.: Transaction Books Inc., 1984.

Artz, Frederick. The Mind of the Middle Ages. U.S.A.: Alfred A. Knopf, $\therefore 1962$.

Aviad, Janet. "Israel: New Fanatics and 01d." Dissent 31 (Summer 1984): $338-343$. 
Avishai, Bernard. The Tradegy of Zionism. New York: Farrar Strauss Girous, 1985.

Baron, Salo Wittmayer. Modern Nationalism and Reliqion. U.S.A.: Meridian Books Inc., 1960.

Barth, Fredrik, ed. Ethnic Groups and Boundaries. Norway: Universitetsforlaget, 1969.

Ben-Dor, Gabriel. State and Conflict in the Middle East. U.S.A.: Praeger Publishers, 1983.

Ben-Dor, Gabriel. "Stateness and Ideology in Contemporary Middle Eastern Politics." The Jerusalem Journal of International Relations 9 (September, 1987): : 10-37.

Ben-Sasson, H.H. and Ettingert, S. Jewish Society Through the Ages. New York: Schocken Books, 1971.

Benvenisti, Meron. Conflicts and Contradictions. New York: Vil Fara Books, 1986.

Ben-Zadok, Efraim and Goldberg, Giora. "Gush Emunim in the West Bank." M1ddie Eastèrn Studies 22 (January 1986): 52.73.

- Berger, Peter. The Sacred Canopy. New York: Doubleday and Company Inc., 1967:

Berkovits, Eliezer. Crisis and Faith. New York: Sanhedrin Press, 1976. Biggar, Nigel; Scatt, Jamie S.; and Schweiker, William, eds. Cittes of Gods. U.S.A.: Greenwood Press, 1986.

Birnbaum, Ervin. The Politics of Compromise: State and Religion in Israel. Rutherford, New Jersey: Fairleigh Dickinson University Press, 1970. 
Blastus, Mark. Ihe Discourse of World Order. Boylder: Westview Press, 1984 .

Bollinger, V.L. "Book Review: Religion and Politics in the Modern World". " Canadian Review of Studies in Nationalism 13 (Fall 1986): $284-286$.

Bourg, Carroll J. "Politics and Religion." Sociological Analysis 41 (Winter 1980): 297-316.

Brass, Paul R. "Ethnicity and Nationality Formation." Ethnicity 3 (September 1976): 225-241.

Brinker, Menachem. "The End of Zionism?." Dissent 32 (Winter 1985): 77-82.

Burgess, Elaine. "The Resurgence of Ethnicity: Myth or Reality?." Ethnic and Racial Studies 1 (July 1978 ): 265-285. . Casanova, Jose. "The Politics of the Religious Revival." IELOS 59 (Spring 1984): 3-34.

Clements, Kevin P. and Drache, Daniel. "Symposium on Progressive Modes of Nationalism in New Zealand, Canada and Australia." Australian and Weitzaland Journal of Sociology 14 (October 1978): 282-284.

Cochran, Clarke E; Perkins, Jerry $\mathrm{D}$; and Havens, Murray $\mathrm{Clark}$. "Public Policy and the Emergence of Religious Politics." Public Policy 35 (Fa11 1987): 595-612.

Connorf Walker. "The Politics of Ethnonationalism." Journal of International Affairs 27 (1973): 1-21.

Connor, Walker. "A Nation is a Nation, is a State, is an Ethnic Group is a..." Ethnic and Racial Studies 1 (October 1978): 377-399. 
Connor, Walker. "Nation-Building or Nation-Destroying?." Herld Politics 24 (April 1972): 319-356.

Cviic, Christopher. "Religion and Nationalism in Eastern Europe: The Case Study of Yugoslavia." Millennium: Journal of International Studies 14 (1985): 195-206.

Deutsch, Karl W. Nationalism and Social Communication. U.S.A.: The M.I.T. Press, 1966.

De Vos, George and Romanucci-Ross, Lola., eds. Ethnic-Identity:

Cultural Continuities and Change U.S.A.: Mayfield

Publishing Company, 1975.

Dobbelaere, Karel. "Secularization Theories and Sociological Paradigms:

A Reformulation of the Private-Public Dichotomy and tho Problem of Societal Integration." Sociological Analys is 46 (Winter 1985): 377-387.

Debbelaere, Karet. "Somg Trends in European Sociology of Religion: The Secularization Debate." Sociological Analysis 48 (Summer 1987): $107-137$.

Dobbelaere, Karel. "Secularization: A Multi-Dimensional Concept."

Current Sociology 29 (Suminer 1981): 3-215. -

Don-Yehiya, Eliezer. "Religfous Leaders in the Political Arena: The Case of Israel." Middle Eastern Studies 20 (April 1984): 151-171. Don-Yehtya, Eljezer. "Jewish Messianism, Religious Zionism Ind Israel! Politics: the Impact and Origins of Gush Emunim." Middle Eastern

Studies 23 (April 1987): 215-134.

Don-Yehiya, Eliezer. "Jewish Orthodoxy, Zionism, and the State of Israel." Jerusalem Quarterly 31 (Spring 1984): 10-30. 
Don-Yehiya, Elfezer. "Origins and Development of the 'Agudah' and

'Mafdal' Parties." Jerusalem Quarterly 20 (Summer 1981): 49-64. Don-Yehiya, Ellezer and Liebman, Charles. Religion and Politics' in

Israel. U.S.A.: Indiana Untversity Press, 1984.

Don-Yehiya, Eliezer and Liebman, Charles. "Zionist UItranationalism and

its Attitude toward Religion." Journal of Church and State 23

(Spring 1981): 259-273.

Don-Yehiya, Eliezer and Liebman, Charles. Civil Religion in Israel.

U.S.A.: University of California Press, 1983.

Dunn, Charles W. "Some Modest Propositions about an Immodest Subject.".

PS 19 (Fall 1986): 832-836...

Eban, Abba. My People. U.S.A.: Behrman House Inc./ Random House, 1968.

Edelstein, Joel C. "Pluralfst and Marxist Perspectives on Ethnicity and

Nation-Building." In Ethnicity and Nation-Building, edited by

Wendell Beil and Walter E. Freeman. U.S.A.: Sage Publications,

1974.

Elam, Yigal. "Gush Emunim: A False Messianism." Jerusalem Quarterly 1 (Fall 1976): 60-69.

- Elon, Amos. Ihe Israel1s:"Founders and Sons. Israel: Adam Press, 1981. Encyclopaedia Britannica Ready Reference. 1985 ed., s.v.

"Enlightenment."

Encyclopaedia Britannica Micropaedia R̂eady Reference. 1985 ed., s.v. "Europe."

Enloe, Cynthia H. Ethnic Conflict and Political Development. U.S.A.:

Little, Brown and Company Inc., 1973.

Epstein, Isidore. Judaism. U.S.A.: Penguin Books, 1959. 


\section{7}

Feldman, Saul and Thielbar, Gerald, eds. Issues in Secial Inequality. Boston: Little, Brown and Company, 1972.

Finkelstein, Louis, ed. The Jews: Their Religion and Culture. New York: Schocken Books, 1971.

Foon, Chew Sock. "On the Incompatibility of Ethnic and National Loyalties: Reframing the Issue." Canadian Revtew of Studies in Nationalism 13 (Spring 1986): 1-12.

Fowler, Robert. Religion and Politics in America. New Jersey: The American Theological Library Association and The Scarecrow Press Inc., 1985.

Frankel, William. Israel Observed. U.S.A.: Thamies and Hudson, 1980. Galston, William A. "Public Morality and Religion in the Liberal State." PS 19 (Fall 1986): 807-824.

Gellner, E.A. Nations and Nationalism. Oxford: Blackwell Publishers, 1983.

Gerth, Hans and Mills, C. Wright:. Character and Social Structure. London: Routledge and Kegan Paul Ltd 1961. Gerth, H.H. and Mills, C. Wright. Erom Max Weber: Essays in Sociology. U.S.A.: Oxford University Press, 1971. Glazer, Nathan. "The Universalisation of Ethnicity." Encounter 44 (February 1975): 8-17.

Glazer, Nathan and Moynihan, Daniel P, eds. Ethnicity; Theery and Experience. U.S.A.: Harvard Untversity Press, 1975. Goldman, Eliezer. Religious Issues in Israel's Political Life. Israel: Jerusalem Post Press, 1964. 
Haas, Ernst B. "What is Nationalism and Why Should We Study It?." International Organisation 40 (Summer 1986): 707-744. Hazelton, Lesley, Jerusalem. Jerusalem. U.S.A.: Penguin Books, 1986. Herman, Simon N. Israelis and Jews. The Continuity of an Identity. New York: Randon House, 1970.

Hertzberg, Arthur. "The Religious Right in the State of Israel." American Academy of Political and Social Sciences 483 (January 1986): $84-92$.

Hertzberg, Arthur. Ihe Zionist Idea. Conneticut: Greenwood Press, 1959.

Hi1l, Mictiael. A Sociology of Religion. London: Heineman Educational Books, 1973.

Himmelfarb, Milton. The Jews of Modernity. New York: Basic Books Inc., 1973.

Hougland, Jr. James G. and Christenson, James A. "Religion and Politics: The Relationship of Religious Participation to Political Efficacy and Involvement." Sociology and Social Research 67 (July 1983): 405-420.

Hoyt, Robert. Europe in the Middle Ages. 2d ed. U.S.A.: Harcourt, Brace and World Ine., 1966.

Isaac, Rael Jean. Party and Politics in Israel: Three Visions of a Jewilsh State: New York: Longman Press, 1981.

Isaac, Rael Jean. Israel Divided. Ideological Politics in the Jewish State. U.S.A.: The John Hopkins University Press, 1976.

Isajtw, Wsevolod W. "Towards a Theory of Ideological Movements: Nationalism and Community Change in Quebec and Flanders." Ganadian Review of Studies in Nationalism 12 (Spring 1985): 141-160. 
Isejiw, Wsevolod W. "Definitions 111-124.

Jansen, Michae1. Dissonance in Zien. United Kingdom: Zed Books, 1987. Jerusalem Post, 20 June 1986. Jerusalem Post Internationat Edition, 13 February 1987. Jerusalem Pest International Edition, 20 February 1987. Jerusalem Post International Edition, 7 March 1987. Jerusalem Post International Edition, 20 June 1987. Jerusalem Post International Edition, 27 June 1987. Jerusalem Post International Edition, 18 July 1987. Jerusalem Post International Edition, 5 Septëmbey 1987. Jerusalem Post International Edition, 12 Sepfember 1987. Jerusalem Post International Edition, 26 September 1987. Jerusalem Post International Edition, 27 September 1987. Jerusalem Post International Edition, 7 November 1987. Jerusalem Post International Edition, 5 December 1987. Jerusalem Post International Edition, 19 December 1987. Jerusalem Post International Edition, 13 February. 1988. Johnpoll, Bernard. Ihe Politics of Futility. New York: Cornell University Press, 1967.

Johnstone, Ronald L. Religion and Society in. Interaction: The Sociology of Religion. New Jersey: Prentice Hall Inc., 1975. Johnstone, Ronald L. Religien in Sectety. U.S.A.: Prentice-Hall Inc., 1983. 
- Juteau-Lee, Danielle. "Ethnic Nationalism: Ethnicity and

Politics." Canadian Review of Studies in Nationalism 11 (Fall 1984): $189-200$.

Kahane, Rabbi Meir. Uncomfortable Questions for Comfortable Jews.

U.S.A.: Lyle Stuart Inc., 1987,

Katz, Jacob. Out of The Ghetto. U.S.A.: Harvard University Press, 1973.

Katz, Jacob. Jewish Emancipation and Self-Emancipation. U.S.A.: The Jewish Publication Society, 1986.

Katz, Jacob. Iradition and Crisis. New York: Schocken Books, 1971.

Kedourie, Elie. Nationalism. Great Britain: Hutchinson and Co. Ltd., 1971.

Kedourle, Elie. "The Nation-State in the Middle East." The Jerusalem Journal of International Relations 9 (September 1987): 1-9.

Kokosalakis, Nikos. "Legitimation Power and Religion in Modern Society." Sociological Analysis 46 (Winter 1985): 367-377.

Krejci, J. Ethnic and Political Nations in Europe. London: Croom Helm Ltd., 1981.

Laqueur, Walter, A History of Zionism.' U.S.A.: Holt, Rinehart and Winston, 1972.

Lenin, V.I. The Right of Nations to Self-Determination. U.S.A.: International Publishers Co. Inc., 1951.

Leslie, Samuel C. Religion and Secularism in Israel. London: Anglo-Israel Assoctation, 1970.

Leslie, Samual. The Rift in Isxael: Religious Authority and Secular Democracy. Great Britain: Routledge and Kegan Paul Ltd., 1971. 
Levine, Daniel. "Is Religion Being Politicized? and Other Pressing Questions Latin America Poses." PS 19 (Fall 1986): 825-831. Levine, Daniel. "Religion and Politics in Comparative and Historical it. Perspective." Comparative Politics 19 (October 1986): 95-122.

Lewis, Bernard. "Islamic Revolution." The New York Review 21 January 1988 , p 46-50.

Liebman, Charles. "Extremism as a Religious Norm." Jeurnal for the Scientific Study of Religien 22 (March 1983): 75-86.

Litani, Yehuda. "The Fanatic Right in Israel." Dissent 32 (Sumner 1985): 315-319.

Loewe, Raphael. "Judaiśn's Eternal Triangle." Religious Studies 23 (1987): 309-323.

- Lofland, John and Richardson, James T. "Religious Movement Organizations: Elemental Forms and Dynamics." In Research in Social Movements, Conflicts and Change, vol.?, edited by Louts Kriesberg. U.S.A: JAI Press, 1984.

Luckmąnn, Thomas. The Invisble Religion. U.S.A.: The Macmillan Company, 1967.

Lustick, Ian.; "Israel's Dangerous Fundamentalists." Foreign Pelicy 68 (Fall 1987): 118-139.

Mahler, Raphael. A History of Modern Jewry: 1780-1815. New York: Schocken Books, 1971.

Marcus, Jonathan. "Israel: The Politics of Piety." Verld Ioday 42 (November 1986): 188-192.

Marmorstein, Emile. Heaven at Bax: The Jewish Kulturkamof in the Holy Land. Great Britain: Oxford University Press, 1969. 
Marty, Martin, ed. Nationaltsm and Religion in America. U.S.A. and' Great Britain: Harper and Row, 1970.

Masters, Roger D. "The Biological Nature of the State." World Politics . 35 (January 1983): 161-193.

McKay, James and Lewins, Frank. "Ethnicity and the Ethnic Group: A Conceptual Analysis and Reformulation." Ethnic and Racial Studies 1 (October 1978): $412-427$.

Merki, Peter and Smart, Ninian, eds. Religion and Politics in the Modern World. U.S.A.: New York University Press, 1983. Minogue, Kenneth R. "National ism: The Poverty of a Concept." Archives Europeennes de Sociologie 8 (1967): 332-343. Nagata, J. "The Status of Ethnicity and the Ethnjicity of Status.".-

- International Journal of Comparative Sociology 17 (1976): $242-260$.

Newman, David. The Impact of Gush Emunim. Great Britain: Croom Helm Ltd., 1985.

01zak, Susan. "Ethnicity and Theories of Ethnic Collective Behaviour." In Research in Social Movements, Conflicts and Change, vol. 8, edited by Louis Kriesberg. U.S.A.: JAI Press Inc, 1984.

Patai, Raphael: The Jewish Mind. New York: Charles Scribner's Sons, 1977.

Raisin, Jacob. The Haskalah Movement in Bussia. 2d ed. U.S.A.: Greenwood Press Publishers, 1972.

Ramet, Pedro., ed. Religion and National ism in Soviet and East European Pelitics. U.S.A.: Duke Press Policy Studies, 1984. 
Reiçhley, A. James. "Democracy and Religion." PS 19 (Fall 1986): 801-806.

Richmond, Anthony. "Ethric Nationalism and Postindustria Xism." Ethnic and Racial Studies 7 (January 1984): 4-18.

Richmond, Anthony. "Ethnic Nationalism: Social Science Paradigms." International Social Science journal 111 (February 1987) : 3-18.

Riggs, Fred W. "What is Ethnic? What is National? Let's turn the Tables." Canadian Review of Studies in Nationalism 13 (Spring 1986): $117-124$.

Robertson, Roland. "Considerations from Within the American Context on the Significance of Church-State Tension." Sociological Analysis 2 (Fall 1981): 193-208.

Robbins, Thomas and Robertson, Roland. "Introduction: Church, State and Sociology." Soctological Analysis 42 (Fall 1981): 191-192.

Rogowski, R. and Tiryakian, E.A., eds. New Nationalisms of the Developed West. Boston: Allen and Unwin Publishers, 1984.

Ronen, $D$. The Quest for Self-Determination. New Haven: Yale University Press, 1979.

Rubinstein, Amnon. "State and Religion" in Israel." Journal of Contemporary History 2 (October $0-7)$ : 107-122.

Rubinstein, Amnon. The Zionist dream Revisited. New York: Schocken Books, 1984.

Sabine, G. and Thorson, T. A History of Political Theory. U.S.A.: Dryden Press, 1973.

Sachar, Howard. A History of Israel: From the Rise of Zionism to Our Iime. New York: Alfred A. Knopf, 1982. 
Sartori, Giovanni. Soctal Science Concepts: A Systematic

Analysis. California: Sage Publications, 1984.

Schermerhorn, R.A. Comparative Ethnic Relations. U.S.A.: The University of Chicago Press, 1978.

Schiff, Gary. Iradition and Politics: The Religious Parties of Israel.

Detroit: Wayne State University Press, 1977.

Schnall, David J. Radical Dissent in Contemporary Israeli Politics. U.S.A.: Praeger Publishers, 1979.

Schwarz, Leo, ed. Great Ages and Ideas of the Jewish People. New York:

The Modern Library, 1956.

Schweid, Eliezer. Israel at the Crossroads. Translated by Alton M.

Winters. U.S.A.: The Jewish Publication Society of America, 1973.

Schweitzer, Avram. Israel The Changing National Agenda. Great Britain:

Croom Helm Ltd., 1986.

Segre, Dan V. ACrisis of Identity. U.S.A.: Oxford University Press, 1980.

Segre, V. D. Israel: A Seciety in Transition. Great Britain: 0xford Untversity Press, 1971.

Seliktar, Ofira. "The Ne Zjonism." Eoreign Policy 51 (Summer 1983): 118-138.

Seton-Watson, Hugh. Nationalisfi-eld and New. Australia: Sydney University Press, 1967.

Shafer, Boyd C. "Book Review: Macro-Nationalisms: A History of the

Ran-Movements." Canadian Rexiew of Studies in National ism 13 (Spring 1986): 133-134. 
Sharkansky, Ira. "Reíigion and State in Begin's Israel." Jerusalem Quarterly 31 (Spring 1984): 31-49.

Sharkansky, Ira. What Makes Israel Lick. U.S.A.: Nel son-Hall, 1985.

Shepard, William E. "Islam and Ideology: Towards a Typology."

International Journal of Middle East Studies 19 (August 1987): $307-336$.

Silver, Eric. "The 'War of the Jews'." Maclean's, 18 January 1988.

Smith, Anthony. "Towards a Theory of Ethntc Separation." Ethnic and Racial Studies 2 (January 1979): $21-37$.

Smith, Anthony. "National Identity and Myths of Ethnic Descent." In Research in Social Movements, Conflicts and Change, vol. 7 , edited by Louis Kriesberg. U.S.A.: JAI Press, 1984.

Smith, Anthony. "Review Article: Ethnic Persistence and National Transformation." The British Jeurnal of Socjelegy 35 (September. 1984): $452-461$.

Smith, Anthony. "Ethnic Myths and Ethnic.Revivals." Archives Europeennies de Sociologie 25 (1984): $283-305$.

Smith, Anthony. "Ethnie and Nation in the Modern World. Aillennium: Journal of International Studies 14 (1985): 127-142.

Smith, Anthony. "Ëthnic Identity and World Order." Millenntumi Journal of International Studies 12 (1983): 149-161.

Smith, Anthony. Nationalism in the Tuentieth Century. Great Britain: Martin Robertson and Co. Ltd., 11979.

Smith, Anthony. Theories of Nationalism. Great Britain: Gerald Duckworth and Co. Ltd., 1983. 
Smith, Donald Eugene. Religion and Political Development. Boston:

Little, Brown and Company, 1970.

Smith, Donald Eugene. Religion. Politics and Social Change in the Third World. U.S.A.: The Free Press, 1971.

Smith, Donald Eugene, ed. Religion and Political Modernization. U.S.Ai: Yale University Press, 1974.

Smoocha, Sammy. Israel: Pluraytsm and Conflict. Great Britain: Routledge and Kegan Paul, 1978.

Spicer, Eduard. "Persistant Cultural Systems." Science 174 (November 1971): 795-800.

Sprinzak, Ehud. "Extreme Politics in Israe1. " Jerusalem Quarterly 5 (Fall 1977): 33-47.

Symmons-Symonolewicz, Konstantin. "The Concept of Nationhood: Toward a Theoretical Clarification." Canadian Review of Studies in Nationalism 12 (Fall 1985): 215-222.

Synder, Louts L. The Dhamics of Nationalism. U.S.A.: D. Van Nostránd Co. Inc, 1964.

Synder, Louis L. "Nationalism and the Flawed Concept of Ethnicity." Canadian Review of Studies in Nationalism 10 (Fall 1983): 253-266.

Synder, Louts L. The Meaning of Nationalism. U.S.A.: Rutger's University Press; 1954.

Tabory, Ephraim. "State and Religion: Religious Conflict Among Jews in Israel." Journal of Chiurch and State 23 (Spring 1981): 275-284.

Tal, Uriel: "Foundations of a Political Messianic Trend in Isráel." The Jerusalem Quarterly 35 (Spring 1985): 36-45. 
Tamney, Joseph B. and Johnson, Stephen D. "Church-State Relations in the Eighties: Public Opinion in Middletown." Sociological Analysis 48 (Spring 1987): 1-16.

Taylor, Henry 0. The Medieval Mind, vol. 1, U.S.A.: Harvard University Press, 1959.

Tessler, Mark. "The Political Right in Israel: Its Origins, Growth, and Prospects." Journal of Palestine Studies 15 (Winter 1986): 12-52. Vatikiotis, P.J. Islam and the State. Great Britain: Croom Helm Ltd., 1987 .

Vital, David. The Origins of Zionism. Great Britain: Oxford University Press, 1975.

Vital, David. Zionism: The Formative Years. Oxford: Clarendon Press, 1982.

von der Mehden, Fred. Religion and Nationalism in Southeast Asta. U.S.A.: The University of Wisconsin Press, 1963. ', Weissbrod, Lilly. "Gush Emunim Ideology." Middle Eastern Studies 18 (Jutly 1983): 265-275.

Weissbrod, Lilly. "Gush Emunim Ideology--From Religious Doctrine to Political Action." Middle Eastern Studies 18. (July 1982): $165-175$.

White, Philip L. "What is a Nationality?." Canadian Review of Studies in Nationalisim 12 (Spring 1985): 1-23.

Wiemer, Reinhard. "The Theories of Nationalism and of Zlonism in the First Decade of the State of Israel." Middle Eastern Studies 23 (April 1987): 172-187.

Wirth, Louis. The Ghetto. 9th ed. U.S.A.: University of Chicago Press, 1966 . 
153

Wolf, Ken. "Ethnic Nationalism: An Analysis and a Defense."

Canadian Review of Studies in Nationalism 13 (Spring 1986): $99-110$.

Yaron, Lvi. "Religion in Israel." American Jewish Yearbook (1976): $41-90$.

ringer, J. Milton. The Scientific Study of Religion. London: The Macmillan Company, 1970.

Tucker, Norman. The Coming Crisis in Israel: Private Faith and Public Policy. U.S.A.: M.I.T. Press, 1973. 

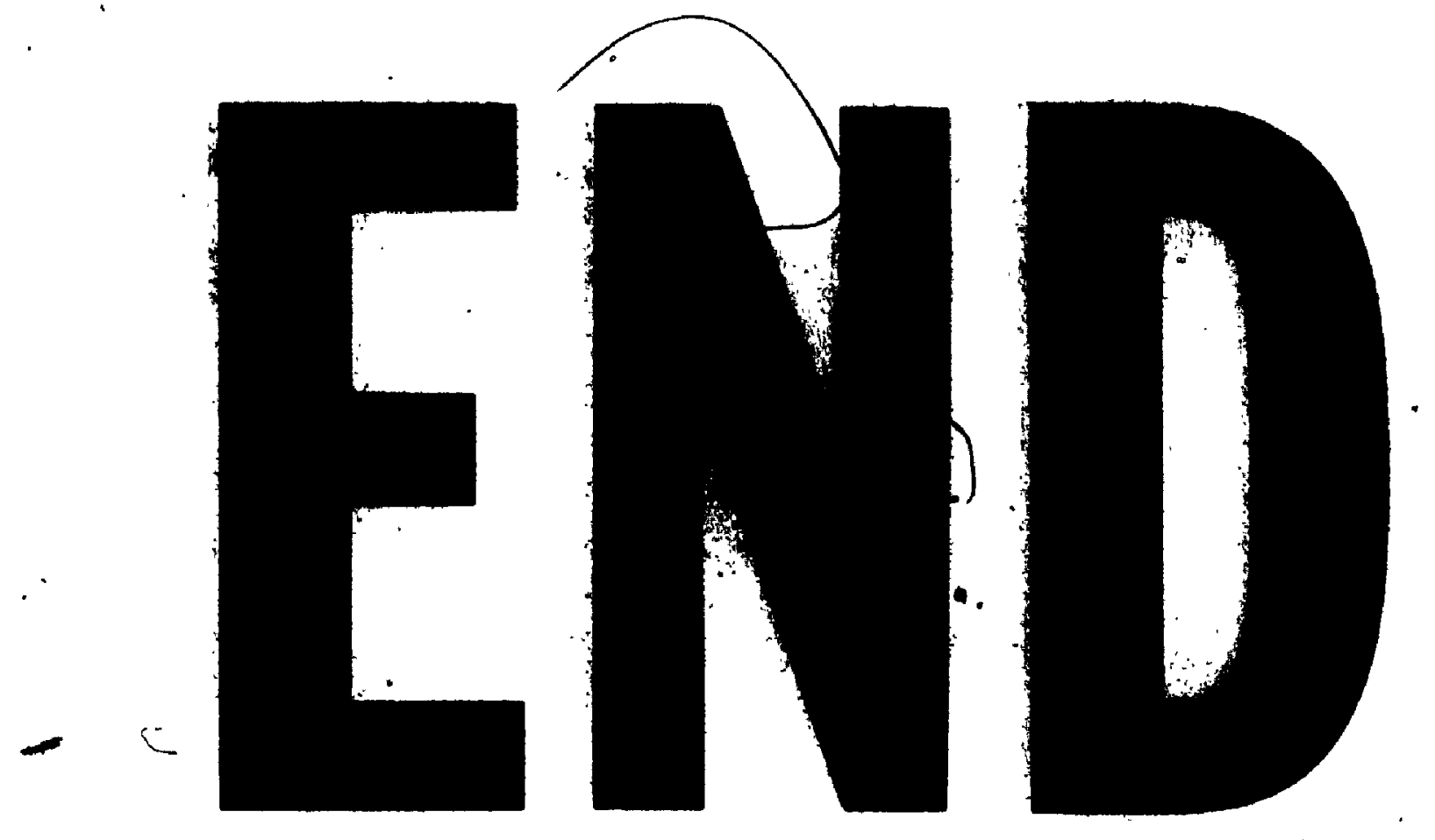

$-1$
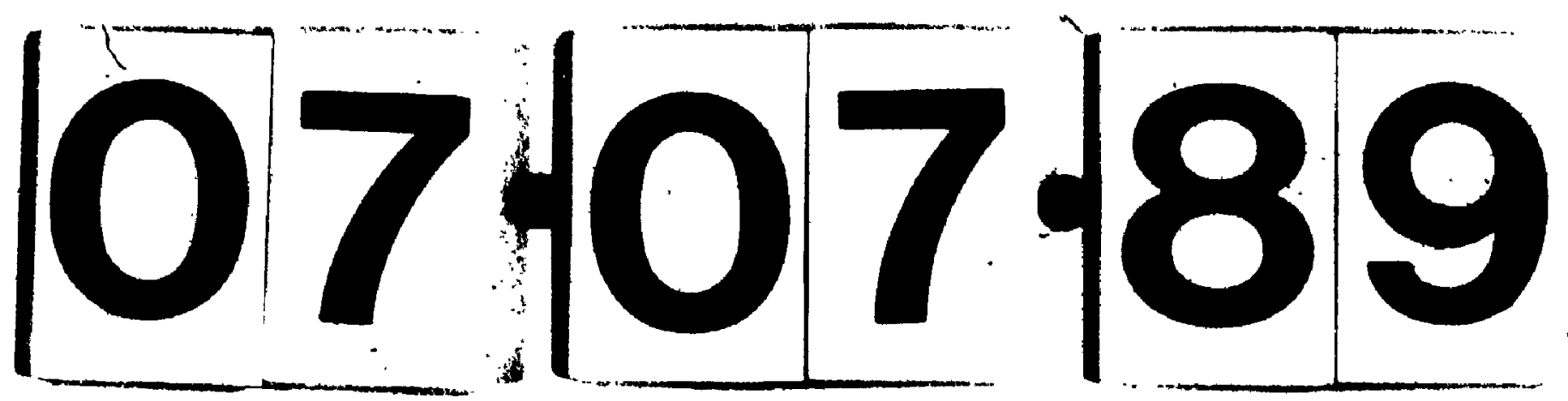

i 